UNIVERSIDADE DE SÃO PAULO

FACULDADE DE CIÊNCIAS FARMACÊUTICAS DE RIBEIRÃO PRETO

\title{
Caracterização funcional e estrutural da hialuronidase isolada da peçonha de serpente Crotalus durissus terrificus
}

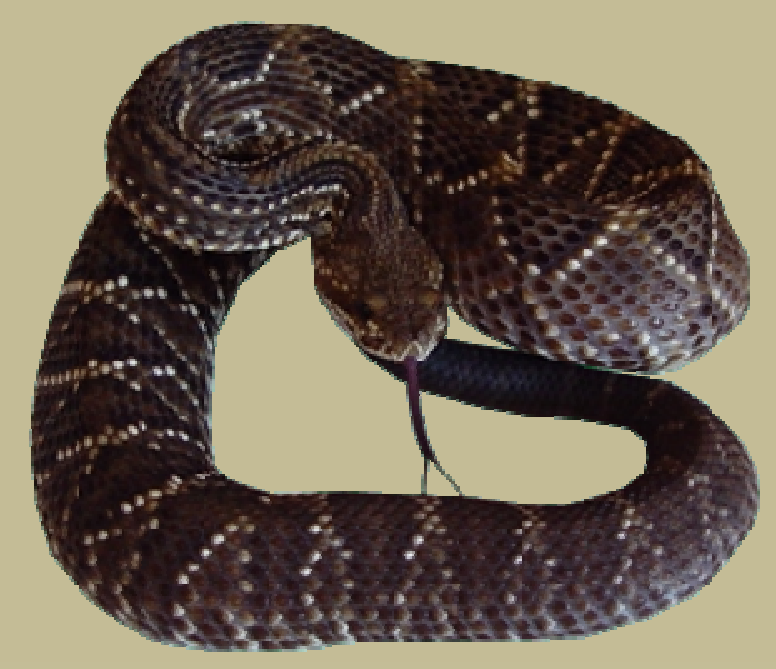

Karla de Castro Figueiredo Bordon

Ribeirão Preto 


\section{UNIVERSIDADE DE SÃO PAULO \\ FACULDADE DE CIÊNCIAS FARMACÊUTICAS DE RIBEIRÃO PRETO}

Caracterização funcional e estrutural da hialuronidase isolada da peçonha de serpente Crotalus durissus terrificus

Tese de Doutorado apresentada ao Programa de PósGraduação em Toxicologia para obtenção do Título de Doutor em Ciências.

Área de Concentração: Toxicologia.

Orientada: Karla de Castro Figueiredo Bordon Orientadora: $\operatorname{Prof}^{\mathrm{a}} \mathrm{Dr}^{\mathrm{a}}$ Eliane Candiani Arantes Braga Coorientadora: $\operatorname{Prof}^{\mathrm{a}} \mathrm{Dr}^{\mathrm{a}}$ Maria Cristina Nonato Costa

Ribeirão Preto 
AUTORIZO A REPRODUÇÃO E DIVULGAÇÃO TOTAL OU PARCIAL DESTE TRABALHO, POR QUALQUER MEIO CONVENCIONAL OU ELETRÔNICO, PARA FINS DE ESTUDO E PESQUISA, DESDE QUE CITADA A FONTE.

Versão corrigida da Tese de Doutorado apresentada ao Programa de PósGraduação em Toxicologia no dia 02/07/2012. A versão original encontra-se disponível na Faculdade de Ciências Farmacêuticas de Ribeirão Preto/USP.

Bordon, Karla de Castro Figueiredo.

Caracterização funcional e estrutural da hialuronidase isolada da peçonha de serpente Crotalus durissus terrificus. Ribeirão Preto, 2012.

126 p. : il. ; $30 \mathrm{~cm}$.

Tese de Doutorado, apresentada à Faculdade de Ciências Farmacêuticas de Ribeirão Preto/USP - Área de concentração: Toxicologia.

Orientadora: Arantes, Eliane Candiani.

1. Crotalus durissus terrificus 2. Hialuronidase. 3. Estudos cinéticos. 4. Atividade antiedematogênica. 5. Cristalografia de proteína. 6. Peçonha. 7. Fosfolipase $A_{2}$. 


\section{FOLHA DE APROVAÇÃO}

Karla de Castro Figueiredo Bordon

Caracterização funcional e estrutural da hialuronidase isolada da peçonha de serpente Crotalus durissus terrificus

Tese de Doutorado apresentada ao Programa de PósGraduação em Toxicologia para obtenção do Título de Doutor em Ciências.

Área de Concentração: Toxicologia.

Orientadora: $\operatorname{Prof}^{\mathrm{a}} \mathrm{Dr}^{\mathrm{a}}$ Eliane Candiani Arantes Braga Coorientadora: Prof $^{\underline{a}}$ Dr $^{\underline{a}}$ Maria Cristina Nonato Costa

Aprovado em:

\section{Banca Examinadora}

Prof. Dr.

Instituição:

Assinatura:

Prof. Dr.

Instituição:

Assinatura:

Prof. Dr.

Instituição:

Assinatura:

Prof. Dr.

Instituição:

Assinatura:

Prof. Dr.

Instituição: Assinatura: 
Dedico esta minha conquista aos amores da minha vida: meu marido Giovani, meu filho Lucas e meus pais Marisa e Marcos.

As palavras são incapazes de expressar minha gratidão pelo amor e apoio que vocês me deram, pela paciência que tiveram e pela confiança que depositaram em mim durante todos estes anos de árduo trabalho e dedicação. 
Àqueles que questionam como consigo conciliar a vida familiar e profissional com a carreira científica, respondo com as palavras de Marie Curie:

"Bem, não tem sido fácil. A vida não é fácil para nenhum de nós. (...) Temos de ter perseverança e, acima de tudo, confiança em nós mesmos. Acreditar que somos capazes de realizar alguma coisa e que essa coisa será alcançada custe o que custar". 


\section{AGRADECIMENTOS}

A Deus, por me ajudar a superar todas as dificuldades e por nunca me desamparar nas horas em que eu mais preciso.

Aos meus pais, Marisa e Marcos, meus exemplos de retidão, moral e desprendimento, pelo amor incondicional, educação, por diversas vezes terem deixado suas vidas de lado para me ajudar com minhas obrigações e por terem cuidado tão bem do Lucas inúmeras vezes para eu poder trabalhar, apesar da distância.

À Profa. Dra. Eliane Candiani Arantes Braga, minha orientadora, por ter me incentivado a fazer Doutorado, por compartilhar seu conhecimento de forma tão empolgante, por ter me ensinado o verdadeiro significado de dedicação e entusiasmo (do grego "en" + "theos", que significa "em Deus") a cada dia. Foi mais fácil e prazeroso trabalhar no ambiente harmonioso de seu laboratório! Obrigada também por ensinar que é importante comemorar cada conquista, cada acontecimento e dar boas gargalhadas. Sorrir faz bem à saúde!

À minha coorientadora, Profa. Dra. Maria Cristina Nonato Costa, pelo apoio, incentivo, sugestões e correções rigorosas, que me ajudaram a amadurecer como pesquisadora e a crescer cientificamente. Que bom que você possui o olhar atento e minucioso necessário para um cristalógrafo!

À Faculdade de Ciências Farmacêuticas, pela estrutura que foi colocada à minha disposição.

Ao Programa de Pós-Graduação em Toxicologia, principalmente à secretária Rose pela ajuda e carinho.

À bibliotecária Maria Cristina Manduca Ferreira, da Biblioteca Central da USP de Ribeirão Preto, pela correção desta Tese quando era apenas um exemplar para Qualificação de Doutorado.

Ao serpentário do Biotério Central, principalmente ao Luís Henrique Pedrosa.

À Maria Aparecida de Almeida Consuli Segato, minha querida amiga Cidinha, pelo ombro amigo nas horas de lágrimas, pelos conselhos motivadores, pelas inúmeras caronas, por toda a ajuda com a burocracia, pelas conversas tão prazerosas... Cidinha, você é uma excelente secretária e uma amiga melhor ainda. Obrigada por todo apoio e grande amizade.

Às amigas Flávia Pine Leite, Juliana Serafim David Costacurta e lara Aimêe Cardoso, que, como eu, sabem como é difícil ser aluna e funcionária, pela ajuda técnica, pelo apoio emocional, por escutarem meus desabafos e indignações... Super Nanny, saiba que todo o tempo que passamos juntas e nossas coversas dão-me força no dia-a-dia.

Ao amigo Fernando Pino Anjolette, pela paciência e pelos infindáveis auxílios com o sequenciador de proteínas e com o liofilizador. Obrigada por sempre estar por perto e disposto a ajudar!

Aos amigos do Laboratório de Cristalografia de Proteínas (LCP-RP), Matheus, Paty, Ricardo, Aline, Giovani (Adam) e Joane pelos bons momentos juntos e pelas discussões, artigos e sugestões sobre cristalografia de proteínas. Ao Matheus e à Joane pela ajuda com as caixinhas, por me ajudarem a "enxergar" os cristais e por esclarecerem dúvidas sobre alinhamentos. 
Aos meus amigos Antônio José Luiz, Amália Lúcia Basso e Maria Angélica dos Santos Cunha Chellegatti (Gelly) pela amizade verdadeira e por estarem sempre dipostos a me auxiliar.

À amiga Taisa Manginelli, pelas boas risadas juntas.

Aos amigos que passaram e deixaram inúmeras boas lembranças: Daniela Trinca Bertazzi, Ana Lúcia Ribeiro Latorre Zimbardi, Cristiane Bregge da Silva, Val, Geny, Cínthia, Welligton, Jamilly, Renatinha, Luana, Laurinha, Ana Paula, Cuco, Veri, Vinicius, Camis.

Ao Sr. Antônio, guarda da FCFRP-USP, por ser tão prestativo, educado, atencioso e eficiente. O senhor é um exemplo de cidadão!

Às amigas morro-agudenses Dona Zoraide e Irene Franchi e Carla Alves Silva Carmanhan, que torcem por mim há anos. caminhos.

Aos meus afilhados Nícolas, Ana Carolina e Isadora, que abrilhantam os meus

Aos meus amigos-irmãos Fransérgio e Gislaine, Adriano e Vanusa, Cassius, Ana Alice e Miguel que estão ao meu lado nos momentos de dificuldades e realizações há anos, dando ombro-amigo, suporte em mudanças, auxílio em formatação de notebook, impressões gráficas, aquisições... tudo isso faz do nosso Conglomerado um grupo cada vez mais forte e unido.

Aos meus irmãos Vinicius e Bruna, aos meus sogros, Alice e Celio, aos meus cunhados Marisa, Saulo, Natalí, Juliana e Daniel, pelo apoio incondicional e incentivo.

Às minhas avós Iracema e Filhinha, pelas orações. E aos meus queridos avôs Pio e José, que olham por mim onde quer que estejam.

Aos amigos do Laboratório de Toxinas Animais (LTA), Rê, Johara, Fefs, Fran, Felipe, Carol, Baldo, Elisa, Pri Carmanhan, Tibério, Ernesto, Pri Shibao, Gi, Amanda e Márcio, pelos momentos agradáveis que me proporcionaram, pelas boas risadas, pela ajuda e pelas discussões que suscitaram excelentes ideias. $\mathrm{E}$ à mãe do $\mathrm{Er}$, pelos seus cookies e cakes deliciosos.

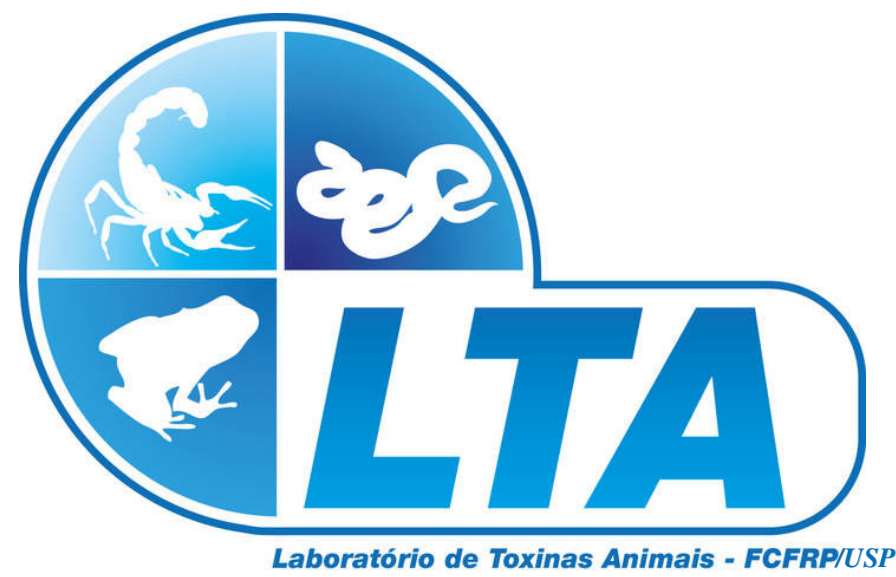

E a todos que direta ou indiretamente ajudaram na concretização deste trabalho. 
Qtm agradecimento todo especial ao mev amado Giovani poi ter me impulsionado a farer Ooutorado e

fro inumeras veres ter sacrificado suas noites de sono e suas obrigacoés fuara me ajudar com as minhas.

Oacé tem um papel fundamental

dentro da mintha vida e cavivira firofissionat.

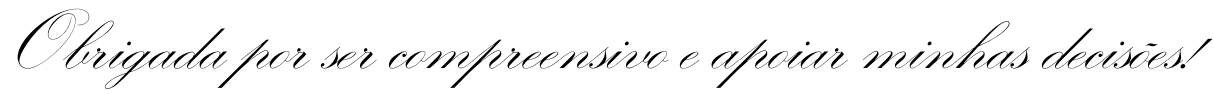

$$
\text { En men quevido fitho Lucas. }
$$

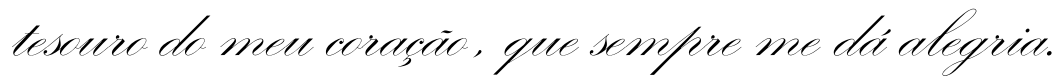

$$
\text { Cau soviso éum bálsamo e }
$$

seus carinhos me fortateceram fraid seguir em frente e te deixair bons exemplos de freiseveranca e determinacion.

- Pego- Phes desculfras pelas noites mat doimidas.

$$
\text { pelas dores de saudade. }
$$

pelos atiasos feo causa do teabatho...

- llas saibam que en momento algum vocés foram esquecidos

$$
\begin{aligned}
& \text { ou colocados em segundo felano. } \\
& \text { Gste periodo saciificante fussou... }
\end{aligned}
$$

- Llas a vitória, os bons exemplos e todo o conhecimento adquiridos durante este feriodo sio feara sempire... 
"Não se esqueça de que quando o elemento rádio foi descoberto, ninguém sabia que seria útil em hospitais.

O trabalho foi ciência pura.

$\mathcal{E}$ isto é uma prova de que o trabalho científico não deve ser considerado do ponto de vista de sua utilidade direta."

Marie Curie

(contemplada com dois Prêmios Nobel:

de Física, em 1903, e de Química, em 1911). 


\section{RESUMO}

BORDON, K. C. F. Caracterização funcional e estrutural da hialuronidase isolada da peçonha de serpente Crotalus durissus terrificus. 2012. 126 f. Tese (Doutorado) - Faculdade de Ciências Farmacêuticas de Ribeirão Preto Universidade de São Paulo, Ribeirão Preto, 2012.

Hialuronidases são responsáveis pela hidrólise de hialuronan, o principal componente da matriz intersticial. Estas enzimas são ubíquas nas peçonhas de serpentes, contudo suas concentrações e características podem variar entre as espécies. Embora estudos indiquem a presença de atividade hialuronidásica na peçonha de Crotalus durissus terrificus e a hialuronidase apresente importante papel no envenenamento local e sistêmico, a enzima ainda não havia sido estudada. Os objetivos deste trabalho focaram $o$ isolamento e a caracterização funcional e estrutural da hialuronidase (CdtHya1) presente na peçonha de serpente Crotalus durissus terrificus. CdtHya1 foi purificada por cromatografia de troca iônica seguida de filtração molecular e interação hidrofóbica (recuperação proteica $=0,23 \%$ ), consistindo no primeiro estudo de isolamento e caracterização de uma hialuronidase crotálica. Os 44 primeiros aminoácidos do seu $\mathrm{N}$-terminal foram determinados por degradação de Edman e mostraram compartilhar um elevado grau de identidade sequencial com outras hialuronidases depositadas em bancos de dados. CdtHya1 é uma glicoproteína e apresentou atividade máxima a $37^{\circ} \mathrm{C}, \mathrm{pH} 5,5$ e na presença de $\mathrm{NaCl}$ 0,2 mol/L. Seu monômero de $64,5 \mathrm{kDa}$ foi estimado por SDS-PAGE sob condições redutoras. A atividade específica da peçonha solúvel foi 145 unidades turbidimétricas reduzidas por miligrama (UTR/mg), contra $5.066 \mathrm{UTR} / \mathrm{mg}$ para CdtHya1. A enzima apresentou $K_{\text {cat }}$ de $3.781,0 \mathrm{~min}^{-1}$ sobre hialuronan e em torno de $400 \mathrm{~min}^{-1}$ sobre os sulfatos de condroitina A, B e C, indicando maior atividade sobre hialuronan. Cátions divalentes $\left(\mathrm{Ca}^{2+}\right.$ e $\left.\mathrm{Mg}^{2+}\right)$ e $\mathrm{NaCl} 1 \mathrm{~mol} / \mathrm{L}$ reduzem significativamente a atividade enzimática. A enzima pura (32 UTR/40 $\mu \mathrm{L}$ ) diminuiu o edema provocado pela injeção subplantar de tampão, crotoxina ou fosfolipase $A_{2}$ $\left(P L A_{2}\right)$, aumentando a difusão destes pelos tecidos dos camundongos. CdtHya1 potencializou a ação da crotoxina, como evidenciado pela morte de camundongos até o final do ensaio de edema de pata. A enzima nativa pura foi submetida a ensaios cristalográficos preliminares onde foram obtidos os primeiros cristais, constituindo assim um passo importante para a determinação da primeira estrutura tridimensional de hialuronidase de peçonha de serpente. Este estudo relata o procedimento de purificação da CdtHya1, a primeira hialuronidase isolada de peçonhas crotálicas com alta atividade antiedematogênica.

Palavras-chave: Crotalus durissus terrificus, hialuronidase, estudos cinéticos, atividade antiedematogênica, cristalografia de proteína, peçonha, fosfolipase $A_{2}$. 


\begin{abstract}
BORDON, K. C. F. Functional and structural characterization of hyaluronidase isolated from Crotalus durissus terrificus snake venom. 2012. $126 \mathrm{f}$. Thesis (Doctoral) - Faculdade de Ciências Farmacêuticas de Ribeirão Preto - Universidade de São Paulo, Ribeirão Preto, 2012.

Hyaluronidases are responsible for hyaluronan hydrolysis, the major component of the interstitial matrix. These enzymes are ubiquitous in snake venoms, however their concentrations and characteristics may vary between species. Although studies indicate the presence of hyaluronidase activity in the Crotalus durissus terrificus venom and hyaluronidase presents important role in local and systemic envenoming, the enzyme has not been studied yet. The objectives of this study focused on the isolation and functional and structural characterization of hyaluronidase (CdtHya1) presents in Crotalus durissus terrificus snake venom. CdtHya1 was purified by ion exchange chromatography followed by molecular filtration and hydrophobic interaction (protein recovery $=0.23 \%$ ), consisting in the first study on the isolation and characterization of a crotalic hyaluronidase. Its first $44 \mathrm{~N}$-terminal amino acids were determined by Edman degradation and showed to share a high level of sequence identity against other hyaluronidases deposited in data banks. CdtHya1 is a glycoprotein and it showed maximum activity at $37^{\circ} \mathrm{C}, \mathrm{pH} 5.5$ and in the presence of $0.2 \mathrm{~mol} / \mathrm{L} \mathrm{NaCl}$. Its monomer of $64.5 \mathrm{kDa}$ was estimated by SDS-PAGE under reducing conditions. The soluble venom specific activity was 145 turbidity reducing units per milligram (TRU/mg), against 5,066 TRU/mg for CdtHya1. The enzyme showed $K_{\text {cat }}$ of $3,781.0 \mathrm{~min}^{-1}$ on hyaluronan and about $400 \mathrm{~min}^{-1}$ on chondroitin sulphates $\mathrm{A}, \mathrm{B}$ or $\mathrm{C}$, indicating higher activity on hyaluronan. Divalent cations $\left(\mathrm{Ca}^{2+}\right.$ and $\mathrm{Mg}^{2+}$ ) and $1 \mathrm{~mol} / \mathrm{L} \mathrm{NaCl}$ significantly reduce the enzyme activity. The pure enzyme (32 TRU/40 $\mu \mathrm{L}$ ) decreased the edema caused by subplantar injections of buffer, crotoxin or phospholipase $\mathrm{A}_{2}\left(\mathrm{PLA}_{2}\right)$, increasing their diffusion through mice tissues. CdtHya1 potentiated crotoxin action, as evidenced by mice death by the end of the paw edema assay. The pure native enzyme was subjected to preliminary crystallographic studies where the first crystals were obtained, thus providing an important step in determining the first three-dimensional structure of hyaluronidase snake venom. This study reports the purification procedure of CdtHya1, the first hyaluronidase isolated from crotalic venoms with high antiedematogenic activity.
\end{abstract}

Keywords: Crotalus durissus terrificus, hyaluronidase, kinetic studies, antiedematogenic activity, protein crystallography, venom, phospholipase $\mathrm{A}_{2}$. 


\title{
LISTA DE ABREVIATURAS E SIGLAS
}

\begin{abstract}
ANOVA Análise de variância estatística
BCTA Brometo de cetiltrimetilamônio

BLAST Ferramenta de alinhamento local básico e de pesquisa (Basic local alignment and search tool)

cDNA DNA complementar
\end{abstract}

CdtHya1 Hialuronidase da peçonha de Crotalus durissus terrificus

CdtV Peçonha de Crotalus durissus terrificus

CLAE Cromatografia líquida de alta eficiência

CMC-52 Carboximetilcelulose-52

Da Unidade de massa atômica Dalton, equivalente à massa de um átomo de ${ }^{1} \mathrm{H}$

DNA Ácido desoxirribonucleico

DTN Doenças Tropicais Negligenciadas

EC Enzyme commission

EDTA Ácido etilenodiaminotetracético dissódico dihidratado

EPM Erro padrão médio

FPLC Cromatografia líquida rápida de proteínas (Fast Protein Liquid Chromatography)

GAG Glicosaminoglicana

GlcNAc N-acetil-D-glicosamina (NAG)

GIcUA Ácido D-glicurônico

$K_{\text {cat }} \quad$ Número de renovação de uma enzima

$K_{c a t} / K_{m} \quad$ Eficiência catalítica de uma reação enzimática

$K_{m} \quad$ Constante de Michaelis-Menten para um dado substrato

LAAO L-aminoácido oxidase 
NFU National Formulary Unit

OMS Organização Mundial da Saúde

PAGE Eletroforese em gel de poliacrilamida

PDB Banco de dados de proteína (Protein data bank)

PEG Polietilenoglicol

$\mathrm{pH} \quad$ Potencial hidrogeniônico

PITC Fenilisotiocianato

PTH-aa Feniltiohidantoína-aminoácido

$\mathrm{PLA}_{2} \quad$ Fosfolipase $\mathrm{A}_{2}$

PMSF Fluoreto de fenilmetil sulfonila

PTH Feniltiohidantoína

RNA Ácido ribonucleico

RNA $_{m} \quad$ RNA mensageiro

SDS Dodecil sulfato de sódio

TEMED Tetrametiletilenodiamina

TFA Ácido trifluoroacético

UTR Unidade turbidimétrica reduzida

$V_{\max } \quad$ Velocidade máxima 


\section{LISTA DE FIGURAS}

Figura 1. Mapa de distribuição geográfica das subespécies de Crotalus durissus.

Figura 2. Estrutura do hialuronan com destaque para a ligação $\beta-1,4$ onde ocorre a hidrólise por hialuronidase.

Figura 3. Alinhamento múltiplo realizado no MultAlin entre hialuronidase de Apis mellifera (bvHyal), hialuronidase bovina (bPH20) e as hialuronidases humana hPH20, Hyal-4, Hyal-2, Hyal-1 e Hyal-3.

Figura 4. Estrutura tridimensional da hialuronidase Hyal-1 de Homo sapiens......

Figura 5. Representação do mecanismo de hidrólise enzimática das hialuronidases.

Figura 6. Fluxograma das etapas de extração e purificação da peçonha de Crotalus durissus terrificus para isolamento da hialuronidase CdtHya1...........

Figura 7. Perfil cromatográfico de CdtV em CMC-52

Figura 8. Perfil eletroforético das frações provenientes da purificação por cromatografia de troca iônica da peçonha bruta solúvel de Crotalus durissus terrificus em gel desnaturante de poliacrilamida a 10\%.

Figura 9. Perfil cromatográfico da fração "CM6" em HiPrep Sephacryl S-100 HR

Figura 10. Perfil cromatográfico da fração "S2" em HiTrap Phenyl-Sepharose.....

Figura 11. Perfil eletroforético das frações com atividade hialuronidásica em gel desnaturante de poliacrilamida a $10 \%$ com hialuronan.

Figura 12. Curva de calibração para determinação da massa molar de proteínas.

Figura 13. Perfil cromatográfico da "CdtHya1" em coluna de fase reversa C4.....

Figura 14. Perfil de atividade hialuronidásica em diferentes $\mathrm{pHs}$ para determinação do $\mathrm{pH}$ ótimo da hialuronidase da peçonha de Crotalus durissus terrificus.

Figura 15. Perfil de atividade hialuronidásica em diferentes temperaturas para determinação da temperatura ótima da hialuronidase da peçonha de Crotalus durissus terrificus. 
Figura 16. Atividade da hialuronidase pura de Crotalus durissus terrificus sobre diferentes substratos através da medida da diminuição de turbidez. A) Controle com adição de enzima inativa. B) Ensaio com a enzima ativa.

Figura 17. Efeito de diferentes concentrações de $\mathrm{NaCl}$ sobre a atividade da hialuronidase da peçonha de Crotalus durissus terrificus usando o método turbidimétrico. A) Controle negativo (sem adição de peçonha). B) Ensaio com a peçonha.

Figura 18. Atividade da hialuronidase pura de Crotalus durissus terrificus em tampão acetato de sódio 0,2 mol/L, pH 5,5 adicionado de diferentes cátions

Figura 19. Curva cinética de Michaelis-Menten para hialuronan.

Figura 20. Curva cinética de Michaelis-Menten para sulfatos de condroitina. A) Sulfato de condroitina A. B) Sulfato de condroitina B. C) Sulfato de condroitina C.

Figura 21. Estruturas de glicosaminoglicanas com algumas diferenças em destaque. A) Sulfato de condroitina A; B) Sulfato de condroitina B; C) Sulfato de condroitina C; D) Hialuronan.

Figura 22. Perfil eletroforético das frações com atividade hialuronidásica em gel desnaturante de poliacrilamida a 10\% corado com reagente de Schiff para detecção de glicoproteínas.

Figura 23. Atividade edematogênica da crotoxina e fosfolipase $A_{2}\left(P L A_{2}\right)$ de Crotalus durissus terrificus na ausência ou presença de hialuronidase (32 $\mathrm{UTR} / 40 \mu \mathrm{L})$.

Figura 24. Sequência amino-terminal inicial da hialuronidase de Crotalus durissus terrificus.

Figura 25. Alinhamento múltiplo realizado no MultAlin entre hialuronidases de quatro espécies de serpentes e o $\mathrm{N}$-terminal inicial da hialuronidase de Crotalus durissus terrificus.

Figura 26. Cristais da hialuronidase da peçonha de Crotalus durissus terrificus. 


\section{LISTA DE TABELAS}

Tabela 1. Recuperação e atividade específica dos componentes cromatografados no processo de purificação da hialuronidase de Crotalus durissus terrificus.

Tabela 2. Atividade hialuronidásica da peçonha de diversas serpentes.

Tabela 3. $K_{c a t}, K_{m}$ e $K_{c a t} / K_{m}$ da hialuronidase de Crotalus durissus terrificus para os substratos testados. 


\section{SUMÁRIO}

Resumo $\quad x$

Abstract $\quad$ xi

Lista de abreviaturas e siglas $\quad$ xii

Lista de figuras $\quad$ xiv

Lista de tabelas $\quad$ xvi

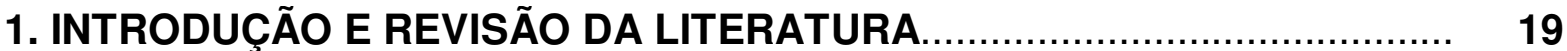

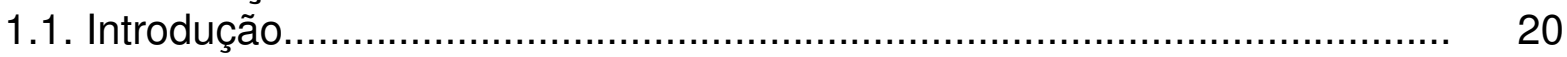

1.2. Revisão da literatura................................................................... 21

1.2.1. Serpentes peçonhentas......................................................... 21

1.2.2. Serpentes do gênero Crotalus: características e distribuição geográfica.

1.2.3. Epidemiologia do ofidismo e serpentes de interesse para a saúde pública.

1.2.4. Peçonha de Crotalus durissus terrificus.

1.2.5. Hialuronan e hialuronidase: um breve histórico.................................... 29

1.2.6. Algumas características e funções das hialuronidases.......................... 30

1.2.7. Hialuronidase de peçonhas ofídicas (EC 3.2.1.35) ............................ 33

1.2.8. Algumas propriedades das hialuronidases: $\mathrm{pH}$, pl e massa molar .......... 35

1.2.9. Moduladores da atividade hialuronidásica.......................................... 37

1.2.10. Medicamentos contendo hialuronidase ............................................ 37

1.2.11. Correlação estrutura e função das hialuronidases.............................. 40

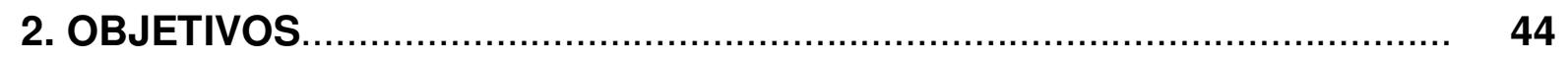

3. MATERIAL E MÉTODOS

3.1. Material e Animais......................................................................... 47

3.1.1. Reagentes, solventes, soluções e matérias-primas............................ 47

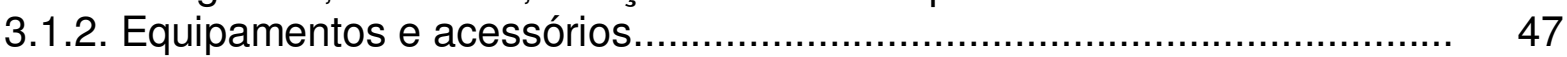

3.1.3. Peçonha................................................................................. 48

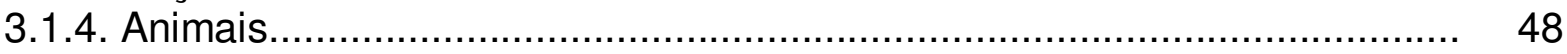

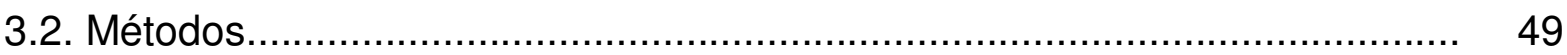

3.2.1. Purificação................................................................................... 49

3.2.1.1. Cromatografia de troca catiônica em CMC-52 da peçonha de Crotalus durissus terrificus........................................................................................ 49

3.2.1.2. Filtração em gel de Sephacryl S-100.............................................. 49

3.2.1.3. Cromatografia de interação hidrofóbica em Phenyl-Sepharose............ 50

3.2.1.4. Cromatografia de fase reversa.................................................... 50

3.2.2. Atividade hialuronidásica........................................................ 52

3.2.2.1. Eletroforese em gel de poliacrilamida com agente desnaturante (SDS-

PAGE) adicionado de hialuronan........................................................... 52

3.2.2.2. Avaliação da atividade hialuronidásica por turbidimetria...................... 52

3.2.2.3. Ensaios de cinética enzimática...................................................... 54

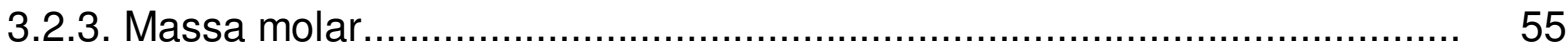

3.2.4. Focalização isoelétrica.................................................................... 55

3.2.5. Identificação de glicoproteínas em gel desnaturante de poliacrilamida.... 56

3.2.6. Atividade edematogênica......................................................... 56 
3.2.7. Sequenciamento amino-terminal..................................................... 57

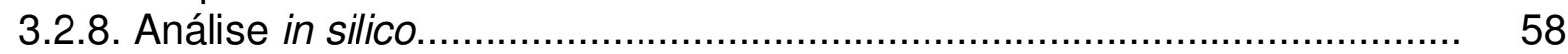

3.2.9. Estudos cristalográficos..................................................................... 58

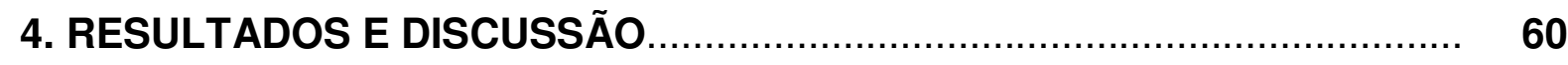

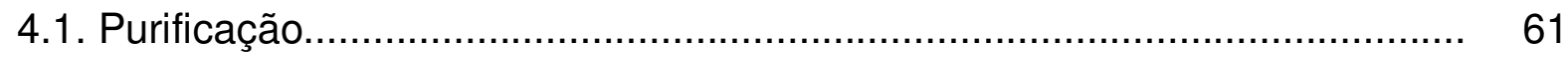

4.1.1. Perfil cromatográfico da CdtV em CMC-52 ....................................... 61

4.1.2. Filtração em HiPrep 16/60 Sephacryl S-100 High Resolution................... 63

4.1.3. Cromatografia de interação hidrofóbica em Phenyl-Sepharose.............. 64

4.1.4. Cromatografia de fase reversa....................................................... 69

4.2. Avaliação da atividade hialuronidásica por turbidimetria............................ 75

4.2.1. Influência do $\mathrm{pH}$..................................................................... $\quad 75$

4.2.2. Influência da temperatura............................................................... 76

4.2.3. Afinidade pelo substrato ................................................................... 78

4.2.4. Efeito da concentração de sal......................................................... 79

4.2.5. Efeito da valência do sal.............................................................. 81

4.2.6. Ensaios de cinética enzimática......................................................... 83

4.3. Identificação de glicoproteínas em gel desnaturante de poliacrilamida... $\quad 88$

4.4. Atividade edematogênica................................................................... 91

4.5. Sequenciamento amino-terminal..................................................... 95

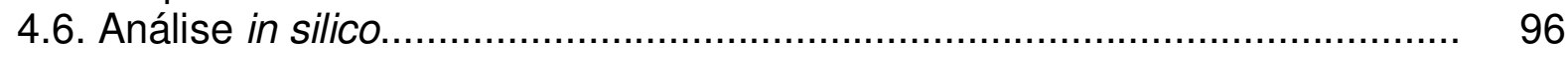

4.7. Estudos cristalográficos................................................................. 100

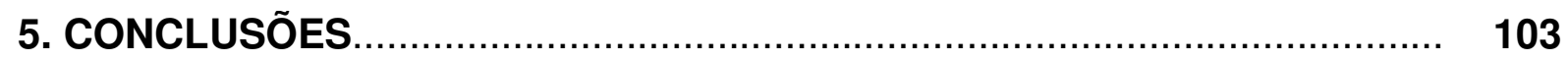

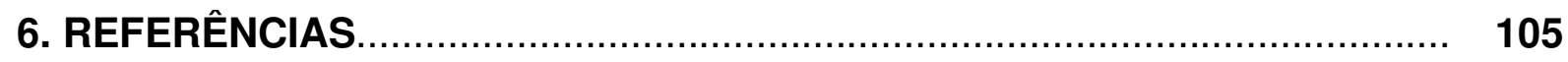

ANEXOS 
1. INTRODUÇÃO E REVISÃO DA LITERATURA 


\subsection{Introdução}

Hialuronidases são enzimas que participam da degradação de glicosaminoglicanas, componentes fundamentais da derme (KREIL, 1995), como o hialuronan e o sulfato de condroitina. São produzidas por bactérias e fungos, estão presentes em nematoides e sanguessugas, secreções de bacteriófagos e outros vírus, tumores malignos, parasitos, crustáceos, lisossomas, esperma de mamíferos, venenos e peçonhas de animais pertencentes a diferentes famílias (STERN; CSÓKA, 2000). Estas enzimas também são encontradas em vários órgãos humanos (testículo, olho, pele, baço, fígado, rins, útero) e fluidos corporais (placenta, lágrima, sangue, esperma, urina) (STERN; JEDRZEJAS, 2006).

As hialuronidases participam de diversos processos biológicos, como fagocitose, mitose, desenvolvimento e implantação de embriões, adesão, migração, proliferação e diferenciação celular (TOOLE et al., 1984; HAKANSSON; VENGE, 1985; KNUDSON; TOOLE, 1987).

Por estarem envolvidas em inúmeros processos relativos à manutenção e integridade da matriz extracelular, têm sido aplicadas em diversas especialidades médicas (MENZEL; FARR, 1998). Estas hialuronoglicosaminidases são usadas para acelerar a difusão e absorção de fuidos (PIRRELLO; CHEN; THOMAS, 2007), promover a redução de edema (JOHNSSON et al., 1999) e aumentar a eficiência de anestésicos (MARTINDALE..., 1982), entre outras aplicações.

A hialuronidase é uma enzima ubíqua nas peçonhas de serpentes (GIRISH et al., 2004), ou seja, é considerada um componente presente em todas as peçonhas ofídicas (IWANAGA; SUZUKI, 1979a), e sua atividade específica é bastante variável entre as diferentes espécies, inclusive entre aquelas pertencentes ao mesmo gênero (BOLDRINI-FRANÇA et al., 2007; KUDO; TU, 2001; PUKRITTAYAKAMEE et al., 1988).

Estas enzimas não são tóxicas, mas potencializam indiretamente a toxicidade dos venenos/peçonhas (GIRISH et al., 2004; TU; HENDON, 1983) ao atuarem como "fator de espalhamento", contribuindo para o envenenamento local ou sistêmico (PUKRITTAYAKAMEE et al., 1988) por facilitar a difusão das toxinas nos tecidos e na circulação das presas/vítimas (PUKRITTAYAKAMEE et al., 1988; TU; HENDON, 
1983; XU et al., 1982; YINGPRASERTCHAI; BUNYASRISAWAT; RATANABANANGKOON, 2003).

A enzima contribui para a destruição tecidual local severa em decorrência da extensa degradação de hialuronan da matriz extracelular e pode causar colapso sistêmico da vítima ao degradar o hialuronan circulante na corrente sanguínea (HARRISON et al., 2007).

Portanto, a neutralização efetiva da atividade hialuronidásica de venenos/peçonhas deve ter prioridade clínica após acidentes ofídicos, visto que há relatos de que a inibição da hialuronidase diminuiu o dano tecidual, a difusão e os efeitos letais de peçonhas ofídicas (GIRISH et al., 2004; GIRISH; KEMPARAJU, 2005, 2006; YINGPRASERTCHAI; BUNYASRISAWAT; RATANABANANGKOON, 2003).

Embora esta enzima apresente importante papel no envenenamento local e sistêmico, há poucos estudos publicados para hialuronidases de peçonhas. Diante da limitada informação com relação às hialuronidases e da importante função desta enzima para a compreensão do mecanismo de ação das peçonhas, este trabalho tem como objetivo o isolamento e a caracterização estrutural e funcional da hialuronidase presente na peçonha de serpente Crotalus durissus terrificus.

Os estudos sobre a hialuronidase apresentados nesta tese demonstram a importância desta enzima no envenenamento por serpentes e poderão contribuir para o desenvolvimento de novas estratégias terapêuticas no caso de acidentes ofídicos, além de auxiliar na compreensão dos inúmeros processos fisiopatológicos nos quais a enzima está envolvida.

\subsection{Revisão da Literatura}

\subsubsection{Serpentes peçonhentas}

Há 3.395 espécies de serpentes conhecidas no mundo, das quais 441 são peçonhentas (UETZ, 2012). Serpentes peçonhentas são aquelas que produzem toxinas em glândulas especializadas e têm aparelhos apropriados para inoculá-las, causando intoxicações sérias no homem e em inúmeros outros animais (BÉRNILS, 
2009; MELGAREJO, 2003). Estas serpentes são encontradas nas famílias Atractaspididae, Colubridae, Elapidae e Viperidae (WARRELL, 2012).

No Brasil são encontradas 375 espécies de serpentes, sendo que 55 são peçonhentas (BÉRNILS; COSTA, 2011). Dentre as peçonhentas, 28 espécies, distribuídas entre os gêneros Bothrops, Bothriopsis, Bothrocophias, Bothropoides, Rhinocerophis, Crotalus e Lachesis, são pertencentes à família dos viperídeos (BÉRNILS; COSTA, 2011).

A família Viperidae é responsável pela maioria dos acidentes ofídicos e pelos mais graves registrados no Brasil e, por esse motivo, é a família de serpentes que causa maior impacto na Saúde Pública (MELGAREJO, 2003). Dada à capacidade de causar acidentes graves que resultam em inúmeras sequelas, o estudo das peçonhas e serpentes é objeto de interesse entre os profissionais da área da saúde.

\subsubsection{Serpentes do gênero Crotalus: características e distribuição geográfica}

As serpentes do gênero Crotalus são terrestres, robustas, pouco ágeis e apresentam chocalho ou guizo no extremo caudal (CAMPBELL; LAMAR, 1989). São serpentes vivíparas, apresentando partos de ninhadas de 6 a 22 filhotes (média de 14), que ocorrem geralmente entre dezembro e fevereiro (MELGAREJO, 2003).

Depois de algumas trocas de pele, surgem anéis queratinizados formando um guizo que produz som característico de chocalho. Crotalus, em latim, e "cascavel", em espanhol, significam chocalho. Acredita-se que a função do guizo esteja relacionada ao mecanismo de defesa da serpente (MUSEU INSTITUTO BUTANTAN, 2010), emitindo um som característico para afugentar possíveis predadores.

Seus habitats são regiões semi-áridas, incluindo florestas tropicais secas ou muito secas e matas de espinhos, mas também áreas abertas relativamente secas (CAMILLO, 1998). Todas as cascavéis sul-americanas são tidas como próprias de formações abertas pouco arborizadas, como formações savânicas e estépicas, contínuas e extensas ou pequenas e fragmentadas (CAMPBELL; LAMAR, 2004; WÜSTER et al., 2005a). 
Seu desenho corológico ${ }^{1}$ cobre tanto áreas naturalmente savânicas e estépicas, quanto áreas originalmente florestadas, mas atualmente transformadas em pastagens ou plantações de grande porte (BÉRNILS, 2009), proliferando-se sobre regiões ambientalmente descaracterizadas (BASTOS; ARAÚJO; SILVA, 2005; MARQUES; ABE; MARTINS, 1998; WÜSTER et al., 2005a, 2005b).

O gênero Crotalus está representado no Brasil por uma única espécie, a Crotalus durissus (C. d.), que tem uma ampla distribuição geográfica, desde o México até a Argentina. Habita os cerrados do Brasil central, as regiões áridas e semi-áridas do Nordeste, os campos e áreas abertas do Sul, Sudeste e Norte (MELGAREJO, 2003). De acordo com Melgarejo (2003), são encontradas cinco subespécies:

- C. d. terrificus: é a mais famosa; encontrada no sul oriental e meridional, desde o Rio Grande do Sul até Minas Gerais, estende-se pelo oeste, até algumas áreas abertas de Mato Grosso, Rondônia, Amazonas e Pará (campos abertos de Humaitá, Serra do Cachimbo e Santarém) (MELGAREJO, 2003; SOERENSEN, 1990); em virtude do desmatamento descontrolado, esta cascavel já é encontrada em algumas áreas alteradas, originalmente com cobertura de mata, adaptando-se bem a elas (MUSEU INSTITUTO BUTANTAN, 2010);

- C. d. collilineatus: distribuída nas regiões secas da zona Centro-Oeste do Brasil, desde o Distrito Federal, Mato Grosso, Mato Grosso do Sul, Goiás, Minas Gerais até o Norte do estado de São Paulo;

- C. d. cascavela: é uma serpente característica das áreas de caatinga do Nordeste do Brasil, ultrapassa 1,60 m de comprimento (MELGAREJO, 2003) e é encontrada desde o Maranhão até o Norte do estado de Minas Gerais (AUTO, 1999); em virtude do desmatamento descontrolado, já é encontrada em alguns pontos do litoral próximo a Salvador-BA (MUSEU INSTITUTO BUTANTAN, 2010).

- C. d. ruruima: encontrada nas savanas de Roraima e em algumas regiões do Amapá, Pará, Amazonas e Rondônia; sua peçonha apresenta peculiaridades nas atividades farmacológicas e, aparentemente, não é bem neutralizada pelos soros anticrotálicos comerciais (MELGAREJO, 2003);

\footnotetext{
${ }^{1}$ Corologia é a ciência que versa sobre a distribuição geográfica de comunidades nas diversas regiões do globo conforme as zonas climáticas e fatores que possibilitam a sua adaptação, principalmente fatores do meio físico (WIKIPEDIA, 2010).
} 
- C. d. marajoensis: é a forma menos conhecida, sendo descrita para as áreas abertas da llha de Marajó, no Pará.

Alguns autores reconhecem uma sexta subespécie no território brasileiro, a $C$. d. trigonicus (AUTO, 1999; CAMILLO, 1998), encontrada em algumas regiões de Roraima e na savana de Rupununi na Guiana (RATELSLANGEN, 2010).

Segundo Bérnils (2009), não há bons mapas de distribuição das subespécies de Crotalus durissus, em parte porque as subespécies desse táxon estão mal definidas, mas também porque nunca foi feito um mapeamento minucioso das cascavéis sul-americanas. Além disso, em virtude do desmatamento descontrolado, as subespécies já são encontradas em algumas outras áreas, adaptando-se bem a elas (MUSEU INSTITUTO BUTANTAN, 2010).

O mapa de distribuição geográfica das subespécies de Crotalus durissus está representado na Figura 1.

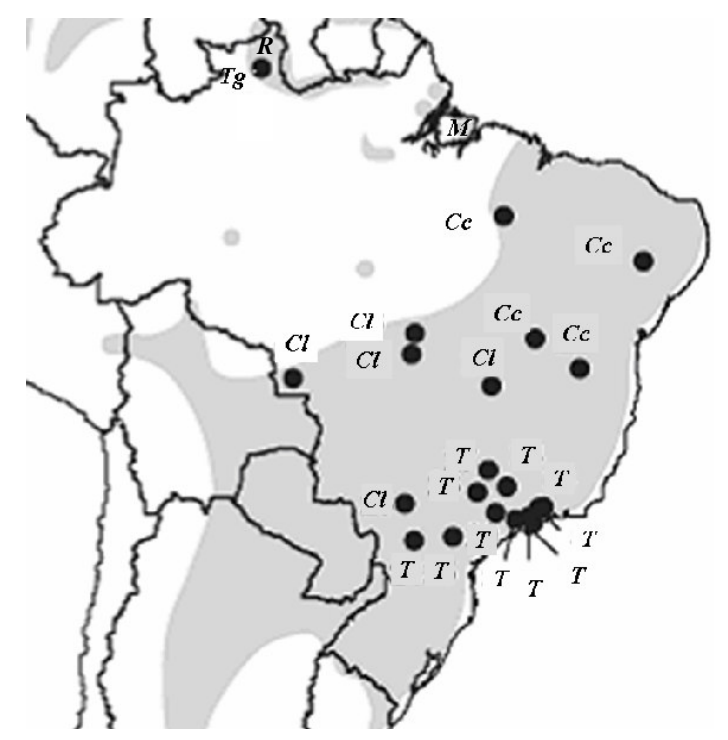

Figura 1. Mapa de distribuição geográfica das subespécies de Crotalus durissus adaptado de Wüster et al. (2005a), com modificações. As áreas sombreadas em cinza indicam a distribuição da espécie Crotalus durissus. Legenda: $\mathbf{T g}$, C. d. trigonicus; $\boldsymbol{R}$, C. d. ruruima; $\boldsymbol{M}, \boldsymbol{C}$. d. marajoensis; $\mathbf{C l}, \boldsymbol{C}$. d. collilineatus; Cc, C. d. cascavella, T, C. d. terrificus.

Por não estarem bem estabelecidas as zonas de intergradação (mutação contínua através de formas intermediárias) entre $C$. $d$. terrificus e outras subespécies (mormente $C$. $d$. collilineatus), a maioria dos autores consultados apresenta apenas mapas de distribuição para a espécie como um todo, mesmo quando, em texto, se reconhece a existência de diferentes subespécies de Crotalus durissus (BÉRNILS, 2009). 


\subsubsection{Epidemiologia do ofidismo e serpentes de interesse para a saúde pública}

Dentre os acidentes por animais peçonhentos, o acidente ofídico é considerado um problema de saúde pública pela sua frequência, gravidade e sequelas marcantes (BRASIL, 2010).

Mais de 300 pessoas morrem todos os dias no mundo vítimas de acidentes com serpentes e a maioria das mortes poderia ser evitada. Grande parte dessas mortes ocorre pela falta do antiveneno específico, pelo retardo na sua administração ou pelo seu uso de forma incorreta (GLOBAL SNAKE BITE INITIATIVE, 2010).

Por ano, quase 5,5 milhões de pessoas são afetadas por acidentes ofídicos no mundo, deixando 2,7 milhões de pessoas seriamente feridas e levando 125 mil a óbito, além de resultar em cerca de 400 mil amputações de membros (CHIPPAUX, 1998; WARRELL, 2010). Esses números são tão impactantes que a Organização Mundial da Saúde (OMS) incluiu, em 2009, os acidentes ofídicos no rol de condições negligenciadas pertencentes à lista do Departamento de Doenças Tropicais Negligenciadas (DTN) (WARRELL, 2010).

A erradicação de condições e doenças negligenciadas é uma das 'Metas de Desenvolvimento do Milênio', estabelecida pela Organização das Nações Unidas (TAMBOURGI, 2010). Desta forma, com a inclusão dos acidentes ofídicos na lista de DTN, espera-se que ocorram investimentos na produção e distribuição de antivenenos, para garantir o acesso aos mesmos. Para tanto, a Sociedade Internacional de Toxinologia endossou em Melbourne, na Austrália, em novembro de 2008, o projeto denominado 'Iniciativa Global para Acidentes com Serpentes' que pretende desenvolver soluções viáveis para os problemas associados aos envenenamentos com serpentes (TAMBOURGI, 2010).

Os acidentes causados por serpentes ocorrem em todas as regiões e estados brasileiros e são um importante problema de saúde quando não se institui a soroterapia de forma precoce e adequada. A ocorrência dos acidentes ao longo do ano apresenta marcada sazonalidade, com predomínio dos casos nos meses quentes e chuvosos e quando aumenta a frequência de trabalho nas áreas rurais (BRASIL, 2001, 2009). A maior incidência (número de acidentes por 100.000 habitantes) foi notificada na região Centro-Oeste, podendo ter ocorrido 
subnotificação nas regiões Norte e Nordeste, devido às dificuldades de acesso aos serviços de saúde nestas regiões (BRASIL, 2001, 2009).

O acidente ofídico é uma doença ocupacional comum e frequentemente devastadora, especialmente nas áreas rurais dos países tropicais em desenvolvimento (WARRELL, 2010). Entretanto, a importância do agravo não é valorizada pelos profissionais de saúde, que desconhecem os aspectos biológicos, clínicos e epidemiológicos envolvidos nos envenenamentos (BRASIL, 2010). O conhecimento dos dados epidemiológicos é importante, pois permite avaliar a relevância do agravo e demonstrar as medidas a serem adotadas para a redução da morbimortalidade ocasionada pelos acidentes ofídicos (BRASIL, 2010).

As serpentes peçonhentas existentes no Brasil foram responsáveis, em 2009, por 27.655 casos de acidentes notificados no Sinan (Sistema de Informação de Agravos em Notificação, do Ministério da Saúde), com 53\% dos casos concentrados entre janeiro e maio (BRASIL, 2010). A incidência em 2009 foi de 14,4 casos por 100 mil habitantes. Do total de casos, $77,7 \%$ acometeu o gênero masculino, $52 \%$ dos casos atingiram a faixa etária de 20 a 49 anos e $78 \%$ dos acidentes aconteceram em zona rural. A letalidade foi de 0,45\% (125 óbitos), sendo que a maioria dos casos fatais (86\%) recebeu tratamento com soro (BRASIL, 2010). Os pacientes chegaram a óbito, mesmo após a utilização do soro, em decorrência da falta do antiveneno específico, do uso de forma incorreta, ou do retardo na administração, principalmente na região Norte, onde o acesso é difícil (BRASIL, 2010).

Os acidentes botrópicos representaram, em 2008, 73\% dos acidentes ofídicos no país, seguido do crotálico (7,4\%), laquético (3\%) e elapídico $(0,7 \%)$ (BRASIL, 2009). No entanto, o maior índice de letalidade com acidentes ofídicos é referente aos acidentes com o gênero Crotalus (BRASIL, 2001). Em 2009, o gênero Crotalus foi responsável pelo maior índice de letalidade (1,25\%), seguido por Micrurus $(1,02 \%)$, Lachesis $(0,7 \%)$ e Bothrops (0,35\%) (BRASIL, 2010).

Com exceção das serpentes do gênero Micrurus, todas as serpentes peçonhentas causam distúrbios na coagulação sanguínea e somente as Crotalus causam miotoxicidade sistêmica (JORGE; RIBEIRO, 1990). As serpentes dos gêneros Lachesis e Bothrops provocam destruição tecidual no local da picada, enquanto as dos gêneros Crotalus e Micrurus bloqueiam a placa motora da fibra muscular (JORGE; RIBEIRO, 1990). 
Acidentes por serpentes do gênero Crotalus são importantes pelo potencial em produzir quadros clínicos graves e até mesmo fatais (GIRISH et al., 2004). É o gênero que causa o maior número de mortes devido à frequência com que os casos evoluem para insuficiência renal aguda (MELGAREJO, 2003). As manifestações clínicas do acidente crotálico são precoces, visto que a peçonha apresenta atividades hemolítica, miotóxica, neurotóxica e nefrotóxica (GIRISH et al., 2004). Os sintomas do envenenamento crotálico caracterizam-se por sinais neurotóxicos (fácies miastênica, fraqueza muscular) e escurecimento da urina (oligúria, anúria) (MELGAREJO, 2003). A peçonha de cascavel provoca quadros clínicos graves com discreta reação local e intensa ação neurotóxica, coagulante e principalmente miotóxica sistêmica que pode levar ao óbito por insuficiência renal aguda e, mais raramente, por insuficiência respiratória (AZEVEDO-MARQUES et al., 1985).

\subsubsection{Peçonha de Crotalus durissus terrificus}

As peçonhas de serpentes são ricas em proteínas e peptídeos que compreendem cerca de 90 a $95 \%$ do seu peso, sendo constituídas por enzimas, como metaloproteases, fosfolipases $\mathrm{A}_{2}\left(\mathrm{PLA}_{2} \mathrm{~S}\right)$, serinoproteases, hialuronidases, Laminoácido oxidases (LAAOs), além de outros componentes sem atividade enzimática. As frações não-proteicas são representadas por fosfolipídios e compostos de baixa massa molar como nucleosídeos, aminas biogênicas e constituintes inorgânicos (BJARNASON; FOX, 1994; CARDOSO, 2003; SOUZA et al., 2000). Estas substâncias biologicamente ativas afetam as funções vitais da vítima/presa, desencadeando severos distúrbios fisiopatológicos (GIRISH; KEMPARAJU, 2011).

As peçonhas ofídicas atuam na imobilização e/ou digestão da presa, embora sua composição varie até mesmo dentre indivíduos de uma mesma espécie, ou do mesmo indivíduo, dada às diferenças de idade, sexo, hábitat, dieta e estação do ano (GIRISH; KEMPARAJU, 2011).

Por serem constituídas por proteínas e peptídeos tóxicos que têm especificidade para diversos receptores, as peçonhas ofídicas são clinicamente desafiadoras e cientificamente fascinantes, especialmente para o desenvolvimento de fármacos (WARRELL, 2010). 
No Brasil, a peçonha crotálica é considerada a mais tóxica e possui letalidade aproximada de $72 \%$ em casos não tratados com soroterapia (DAVIDSON; SCHAFER; MOSEMAN, 1993). A peçonha de Crotalus durissus terrificus tem sido uma das mais estudadas desde 1938, quando Slotta e Fraenkel-Conrat isolaram e cristalizaram a crotoxina (Slotta; Fraenkel-Conrat ${ }^{2}$ apud HENDON; FRAENKELCONRAT, 1971). O complexo crotoxina representa quase $50 \%$ do peso seco da peçonha e é formado por duas subunidades diferentes: A (ácida), denominada crotapotina, e B (básica), com elevada atividade fosfolipásica $\left(\mathrm{PLA}_{2}\right)$ denominada crotactina. A crotactina (B) apresenta toxicidade moderada e a crotapotina (A) é destituída de atividade tóxica ou enzimática. A crotapotina age como uma chaperona, aumentando a toxicidade da $\mathrm{PLA}_{2}$ cerca de 10 vezes no complexo crotoxina (HABERMANN; BREITHAUPT, 1978; RUBSAMEN; BREITHAUPT; HABERMANN, 1971).

Da mesma peçonha foram isoladas outras neurotoxinas: crotamina (Laure ${ }^{3}$ apud KONNO et al., 2008), giroxina (SEKI; VIDAL; BARRIO, 1980) e convulxina (PRADO-FRANCESCHI; VITAL BRAZIL, 1981), além de outros componentes, como o peptídeo crotalfina (KONNO et al., 2008), um potente analgésico que atua em receptores opioides periféricos (GUTIERREZ et al., 2008).

$\mathrm{Na}$ peçonha de cascavel também foram identificadas várias isoformas de crotoxina (FAURE; BON, 1997), PLA 2 (TOYAMA et al., 2000, 2003), crotapotina e crotamina (TOYAMA et al., 2000). Foi isolada também uma enzima trombina-símile utilizada como "selante de fibrina" (BARROS et al., 2009). O mecanismo de ação desta protease consiste em mimetizar o sistema de coagulação para interromper o extravasamento sanguíneo, funcionando como um agente hemostático efetivo e selante para tecidos lesionados (BARROS et al., 2009).

Além de todos esses componentes, a peçonha de Crotalus durissus terrificus também apresenta atividade hialuronidásica por hidrolisar hialuronan (BOLDRINIFRANÇA et al., 2007), no entanto a enzima ou grupo de enzimas responsáveis por esta ação ainda demanda estudos.

\footnotetext{
${ }^{2}$ SLOTTA, K.; FRAENKEL-CONRAT, H. Schlangengifte III. Mitteilung: Reinigung und Kristallisation des Klapperschlangengiftes. Bericht Deutsche Chemische Gesellschaft, v. 71, p.1076-1081, 1938.

${ }^{3}$ Laure, C. J. The primary structure of crotamine. Hoppe-Seyler's Zeitschrift für Physiologische Chemie, Berlin, v. 356, p.213-215, 1975.
} 


\subsubsection{Hialuronan e hialuronidase: um breve histórico}

O ácido hialurônico, cujo nome vem de hyaloid (vítreo) + ácido urônico, descoberto no humor vítreo bovino por Meyer e Palmer (1934), é uma glicosaminoglicana (GAG) linear, principal componente da matriz intersticial. Atualmente, esta macromolécula é frequentemente referida como "hialuronan", pois existe in vivo como um poliânion e não como a forma acídica protonada (HASCALL; LAURENT, 1997).

O termo hialuronan foi introduzido em 1986 para obedecer a nomenclatura internacional de polissacarídeos (NECAS et al., 2008) e é atribuído a Endre Balazs (BALAZS et al., 1986), que o criou para abranger as diferentes formas que a molécula pode tomar, por exemplo, a forma ácida, o ácido hialurônico, e os sais, como o hialuronato de sódio, que se formam em pH fisiológico (LAURENT, 1989).

O hialuronan é uma GAG presente na maioria dos tecidos, com importante papel na manutenção da integridade estrutural do tecido. Sob condições homeostáticas, é encontrado como um polímero de elevada massa molar (cerca de

$10^{6} \mathrm{Da}$ ), sendo despolimerizado a fragmentos de baixa massa molar sob condições de estresse, como por exemplo injúria tecidual (NOBLE, 2002).

Weissman e Meyer (1954) determinaram a estrutura química do motivo (motif) dissacarídeo que se repete, formando o hialuronan. Mostraram que o ácido urônico e o amino-açúcar do dissacarídeo são o ácido D-glicurônico e a N-acetil-Dglicosamina e que eles estão ligados por ligações glicosídicas $\beta-1,4$ e $\beta-1,3$ alternantes (WEISSMAN; MEYER, 1954).

O turnover do hialuronan em mamíferos, no qual estão envolvidas enzimas denominadas hialuronidases, é surpreendentemente elevado para um componente da matriz extracelular. Um indivíduo de $70 \mathrm{Kg}$ possui cerca de $15 \mathrm{~g}$ de hialuronan, um terço do qual se renova diariamente. O hialuronan tem diferentes taxas de turnover, de acordo com o tecido: na pele, que contém $50 \%$ do hialuronan corpóreo total, a meia-vida é de um dia; na cartilagem, de uma a três semanas; na corrente sanguínea, de dois a cinco minutos (STERN; CSÓKA, 2000).

Nos tecidos de vertebrados, a degradação de hialuronan ocorre pela ação simultânea de três enzimas: uma hialuronidase, uma $\beta$-glicuronidase e uma $\beta-\mathrm{N}$ acetilglicosaminidase. A clivagem endolítica pela hialuronidase gera números 
crescentes de terminações não-redutoras para as exoglicosidases que removem açúcares dessas terminações (STERN; CSÓKA, 2000).

A primeira hialuronidase de vertebrado foi identificada em 1928 por DuranReynals (STERN; JEDRZEJAS, 2006). Duran-Reynals (1931) mostrou que em certos órgãos, e especialmente no testículo, existe um fator que é capaz de aumentar as infecções causadas por vírus e bactérias. Inicialmente, foi denominada mucinase por Chain e Duthie (CHAIN; DUTHIE, 1939) por diminuir a viscosidade da mucina do líquido sinovial e liberar substâncias redutoras. O termo "hialuronidase" foi introduzido por Karl Meyer para indicar as enzimas que degradam hialuronan apenas em 1940 (Meyer ${ }^{4}$ et al. apud STERN; CSÓKA, 2000) e, embora a característica de "fator de espalhamento" tenha sido descrita em diversas publicações anteriores (CHAIN; DUTHIE, 1939; CLAUDE; DURAN-REYNALS, 1937; HOFFMAN; DURANREYNALS, 1931; MCCLEAN; HALE, 1940), a relação entre "fator de espalhamento" e hialuronidase só foi discutida a partir de 1940 (Meyer ${ }^{4}$ et al. apud STERN; CSÓKA, 2000).

\subsubsection{Algumas características e funções das hialuronidases}

As hialuronidases são classes de enzimas que degradam, predominantemente, hialuronan. O termo "hialuronidase" é, de certa forma, um termo impróprio, já que estas enzimas degradam também condroitina e sulfato de condroitina, embora em uma proporção bem menor (STERN; JEDRZEJAS, 2006).

Meyer classificou os diferentes tipos de hialuronidase em três subclasses distintas, baseadas em análises bioquímicas e nos produtos das reações enzimáticas (STERN; CSÓKA, 2000):

1) Hialuronidases (EC 3.2.1.35): são hialuronoglicosaminidases que têm como produto principal o tetrassacarídeo (GlcUA-GIcNAc-GlcUA-GIcNAc) ${ }^{5}$. Possuem atividades hidrolítica e de transglicosidase, podendo degradar hialuronan, sulfato de condroitina (principalmente sulfato de condroitina A, também conhecido como condroitina-4-sulfato ou C4S, e sulfato de condroitina $\mathrm{C}$, também denominado

\footnotetext{
${ }^{4}$ MEYER, K.; HOBBY, G. L.; CHAFFEE, E.; DAWSON, M. H. Relationship between "spreading factor" and "hyaluronidase." Proceedings of the Society for Experimental Biology and Medicine, Malden, v. 44, p. 294, 1940.

${ }^{5}$ GlcUA= ácido glicurônico, GlcNAc= N-acetilglicosamina.
} 
condroitina-6-sulfato ou C6S) e, em menor extensão, o sulfato de dermatana (também chamado de sulfato de condroitina B ou beta-heparina). São encontradas em espermatozoides de mamíferos, lisossomas, venenos de himenópteros e peçonhas de serpentes.

2) Hialuronidases (EC 3.2.1.36): são hialuronoglicuronidases que têm como produto principal o tetrassacarídeo ou o hexassacarídeo. Estas enzimas, também chamadas hialuronato 3-glicanohidrolases, estão presentes em sanguessugas, parasitos e crustáceos.

3) Hialuronidases (EC 4.2.2.1 - antiga EC 4.2.99.1): são hialuronato liases produzidas por bactérias que degradam hialuronan, sulfato de condroitina e sulfato de dermatana. São endo- $\beta-N$-acetil-D-hexosaminidases que operam via $\beta$-eliminação produzindo dissacarídeos que contêm resíduos de glicuronosil apresentando uma ligação dupla entre os carbonos 4 e 5.

As hialuronidases são amplamente distribuídas na natureza (GIRISH; KEMPARAJU, 2007; MENZEL; FARR, 1998) e participam da degradação de glicosaminoglicanas (GAGs), componentes fundamentais da derme (KREIL, 1995), como o hialuronan e o sulfato de condroitina que são encontrados juntos na natureza. Entretanto, algumas hialuronidases possuem especificidade absoluta para hialuronan, como as de Pneumococcus e de Streptomyces (STERN; CSÓKA, 2000).

Estas enzimas são encontradas em vários órgãos humanos (testículo, olho, pele, baço, fígado, rins, útero) e fluidos corporais (placenta, lágrimas, sangue, esperma), em bactérias e em secreções de bacteriófagos e outros vírus (STERN; JEDRZEJAS, 2006), em Streptococcus pyogenes e Clostridium perfringens (OHYA; KANEKO, 1970; PRITCHARD et al., 1994), fungos (SHIMIZU et al., 1995), nematoides e sanguessugas (CSÓKA; FROST; STERN, 1997) e nas peçonhas de serpentes (PUKRITTAYAKAMEE et al., 1988; XU et al., 1982), abelhas (OWEN, 1983), aranhas (DA SILVEIRA et al., 2007; NAGARAJU; DEVARAJA; KEMPARAJU, 2007; TU; HENDON, 1983), escorpiões (COSTAL-OLIVEIRA et al., 2012; PESSINI et al., 2001; RAMANAIAH; PARTHASARATHY; VENKAIAK, 1990), vespa Vespula vulgaris (SKOV et al., 2006), vespão Dolichovespula maculata (LU; KOCHOUMIAN; KING, 1995), taturana Lonomia obliqua (GOUVEIA et al., 2005), lagarto Heloderma horridum horridum (TU; HENDON, 1983), arraia de água doce Potamotrygon motoro 
(MAGALHÃES; DA SILVA; ULHOA, 2008) e peixes (POH et al., 1992), assim como em tumores malignos (PODYMA et al., 1997) e numerosos tecidos animais (BOLLET; BONNER; NANCE, 1963).

O sistema hialuronan / hialuronan-sintetase / hialuronidase desempenha um importante papel em muitos processos biológicos envolvendo a manutenção e a integridade da matriz extracelular e suas interações com a superfície da célula (TOOLE et al., 1984). Estes processos incluem fagocitose (FORRESTER; BALAZS, 1980), adesão celular (BARNHART; COX; KRAEMER, 1979), migração (BERNANKE; ORKIN, 1984; HAKANSSON; VENGE, 1985), mitose (BRECHT et al., 1986), desenvolvimento e implantação de embriões (BERNANKE; ORKIN, 1984; CARSON; DUTT; TANG, 1987) e diferenciação (KNUDSON; TOOLE, 1987).

Outro processo afetado por esse sistema é a proliferação celular normal e em tumores (IKEGAMI-KAWAI; TAKAHASHI, 2002). A capacidade de invasão é um dos atributos fundamentais das células de tumor maligno, conferindo-lhes a capacidade de se infiltrar nos interstícios teciduais locais, passar através de barreiras de membranas e penetrar em vasos linfáticos e sanguíneos, e, desta forma, produzir metástases em outros locais. Há várias evidências de que o mecanismo da invasão maligna depende da liberação contínua de glicosidases lisossomais (hialuronidases) e talvez de outras enzimas lisossomais (as proteases neutras e a colagenase), pelas células invasoras (CAMERON; PAULING; LEIBOVITZ, 1979).

Entre as hialuronidases humanas, Hyal-1 e Hyal-2 são as principais para degradação do hialuronan em tecidos somáticos (STERN; JEDRZEJAS, 2006). Quanto à interação com substratos, Hyal-2 possui uma especificidade incomum pelo hialuronan, clivando-o em fragmentos de tamanho intermediário de aproximadamente 20 kDa (STERN; CSÓKA, 2000). Os produtos da digestão de Hyal-2 são degradados a oligossacarídeos de baixa massa molar pela ação da Hyal1 (STERN; CSÓKA, 2000) e o hialuronan é catabolizado por efeitos coordenados de Hyal-1 e Hyal-2 (STERN, 2008). A PH-20, também conhecida como SPAM-1 (Sperm Adhesion Molecule-1), e a Hyal-3 são altamente expressas nos testículos, mas não se sabe se a Hyal-3 participa ou não do processo de fertilização (STERN; CSÓKA, 2000). Hyal-3 e Hyal-4 não são bem conhecidas (STERN; JEDRZEJAS, 2006). A Hyal-4 é uma condroitinase sem atividade sobre hialuronan, sendo a primeira 
enzima puramente condroitinase identificada em tecidos de vertebrados (STERN; CSÓKA, 2000).

A principal função da hialuronidase para fungos e bactérias é fornecer nutrientes para estes organismos através da degradação do substrato. Além disso, a enzima facilita a difusão do agente patogênico e de suas toxinas (HYNES; WALTON, 2000).

As hialuronidases de nematoides gastrointestinais invasivos, como Ancylostoma caninum e Anisakis simplex, estão envolvidas na histólise do tecido e na invasão da mucosa (HOTEZ et al., 1994), e as de sanguessugas facilitam a ruptura do tecido da presa (HOVINGH; LINKER, 1999).

A enzima também é relacionada ao hábito hematofágico dos insetos telmófagos, sendo encontrada na saliva de espécies dos gêneros Phlebotomus e Lutzomyia (VOLFOVA et al., 2008). A hialuronidase alarga a lesão alimentar e difunde agentes anti-hemostáticos no tecido do hospedeiro, o que garante 0 estabelecimento da microhemorragia provocada pela picada e facilita a aquisição de sangue pelo inseto (SILVA, 2009; VOLFOVA et al., 2008).

Portanto, a atividade hialuronidásica está envolvida em diversas condições patofisiológicas, incluindo difusão de toxinas/venenos, fertilização, metástase, infecções microbianas, pneumonia, sepse, bacteremia, meningite, cicatrização, embriogênese, angiogênese, inflamação e alergia, entre outras (GIRISH et al., 2009).

\subsubsection{Hialuronidase de peçonhas ofídicas (EC 3.2.1.35)}

A enzima hialuronidase (EC 3.2.1.35) é a subclasse utilizada neste trabalho, pois está presente na maioria das peçonhas de serpentes.

A classificação numérica no Enzyme Comission, EC 3.2.1.35, baseia-se na reação química que elas catalisam:

- 3 Hidrolases: formam dois produtos a partir da hidrólise do substrato;

- 3.2 Glicosilases: clivam ligações N-glicosídicas;

- 3.2.1 Glicosidases: hidrolisam compostos O-glicosil e S-glicosil;

- 3.2.1.35 hialuronoglicosaminidase. 
Estas enzimas hidrolisam hialuronan na ligação $\beta-1,4$ entre os resíduos $N$ acetil-D-glicosamina e ácido D-glicurônico (Fig. 2).

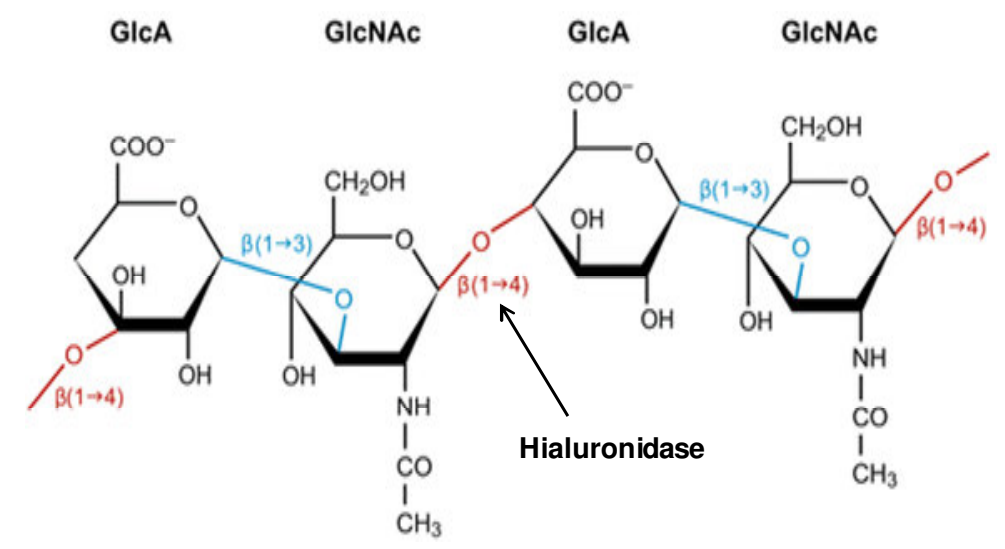

Figura 2. Estrutura do hialuronan com destaque para a ligação $\beta-1,4$ onde ocorre a hidrólise por hialuronidase. O hialuronan é composto por unidades repetidas de ácido D-glicurônico (GlcA) e $\mathrm{N}$-acetil-D-glicosamina (GlcNAc). As unidades dissacarídicas são ligadas por uma ligação $\beta(1 \rightarrow 4)$ (vermelho). Duas unidades dissacarídicas estão apresentadas na figura (JIANG; LIANG; NOBLE, 2007).

O papel desta enzima como "fator de espalhamento" na ação tóxica da peçonha foi confirmado experimentalmente (TU; HENDON, 1983), devido a sua capacidade de hidrolisar o hialuronan e sulfatos de condroitina A e C, facilitando a difusão de toxinas através dos tecidos e da circulação sanguínea da presa/vítima (PUKRITTAYAKAMEE et al., 1988; TU; HENDON, 1983; XU et al., 1982; YINGPRASERTCHAI; BUNYASRISAWAT; RATANABANANGKOON, 2003).

Embora não sejam toxinas (GIRISH et al., 2004; XU et al., 1982), as hialuronidases indiretamente potencializam a toxicidade de peçonhas (GIRISH et al., 2004; TU; HENDON, 1983), contribuindo para o envenenamento local ou sistêmico (PUKRITTAYAKAMEE et al., 1988).

A extensa degradação de hialuronan da matriz extracelular no local da picada contribui para a destruição tecidual local severa, algumas vezes de forma permanente (HARRISON et al., 2007). Além disso, a entrada de hialuronidase de peçonha na corrente sanguínea degrada o hialuronan circulante, podendo causar colapso sistêmico da vítima (HARRISON et al., 2007).

Em estudos experimentais, a neutralização da hialuronidase por anticorpos monoclonais ou derivados extraídos de plantas inibiu o dano tecidual, a difusão e os efeitos letais de peçonhas ofídicas (GIRISH et al., 2004.; GIRISH; KEMPARAJU, 
2005, 2006; YINGPRASERTCHAI; BUNYASRISAWAT; RATANABANANGKOON, 2003). Entretanto, apesar do importante papel no envenenamento, a enzima tem sido ignorada, como é evidenciado pelo reduzido número de estudos publicados. Sua falta de toxicidade (XU et al., 1982), quando isolada, provavelmente explica essa negligência. Outro fato é que as hialuronidases desafiam os pesquisadores, pois são difíceis de purificar (STERN; CSÓKA, 2000) e estão presentes em baixíssimas quantidades nas peçonhas ofídicas (KEMPARAJU; GIRISH; NAGARAJU, 2010).

Embora existam cerca de 400 serpentes peçonhentas entre mais de 3.000 espécies conhecidas no mundo (http://www.reptile-database.org) e hialuronidases sejam ubíquas nas peçonhas ofídicas (GIRISH et al., 2004; IWANAGA; SUZUKI, 1979), há poucos estudos sobre isolamento de hialuronidase ofídica. A enzima foi isolada da peçonha de serpentes Agkistrodon acutus (XU et al., 1982), Agkistrodon contortrix contortrix (KUDO; TU, 2001), Naja naja (GIRISH et al., 2004), Agkistrodon blomhoffii ussurensis (ZHONG et al., 2010) e Daboia russelli (MAHADESWARASWAMY et al., 2011).

Pelo fato de a produção de antivenenos ser baixa e a mordida de serpentes ser uma ameaça presente em muitas comunidades, tanto de nações desenvolvidas como subdesenvolvidas (CHEN et al., 2002), espera-se que estudos bioquímicos, farmacológicos e moleculares da hialuronidase presente na peçonha de cascavel colaborem para a otimização de terapias para o envenenamento ofídico.

\subsubsection{Algumas propriedades das hialuronidases: $\mathrm{pH}, \mathrm{pl}$ e massa molar}

Muitos tipos de hialuronidases foram estudados, de procariotos a eucariotos, observando-se uma grande diversidade na atividade destas enzimas entre as diferentes espécies (MIO et al., 2001). Essa variedade foi verificada para a faixa de $\mathrm{pH}$ ótimo, pl, número de isoformas encontradas, massa molar estimada, especificidade para substratos e sensibilidade a diferentes moduladores.

O pH ótimo varia entre 3,3 e 7,0. De acordo com Gregory et al. ${ }^{6}$ (apud GIRISH et al., 2004), as hialuronidases são geralmente classificadas como enzima

\footnotetext{
${ }^{6}$ GREGORY, F. I.; TONY, C.; STERN, R. The hyaluronidases: a chemical, biological and clinical overview. Trends in Glycoscience and Glycotechnology, v. 8, p. 419-434, 1996.
} 
ácido-ativa (ativa entre $\mathrm{pH} 3$ e 4) ou neutro-ativa (ativa entre $\mathrm{pH} 5$ e 6). Os valores de pH também variam entre as enzimas humanas, que são um grupo de cinco endoacetil-hexoaminidases, denominadas Hyal-1, Hyal-2, Hyal-3, Hyal-4 e PH-20, com cerca de $40 \%$ de identidade entre elas (STERN; CSÓKA, 2000). Por exemplo, a Hyal-1 humana é uma enzima ácido-ativa com atividade máxima em $\mathrm{pH} 3,7$ (STERN; CSÓKA, 2000) e é cerca de cem vezes mais ativa na urina do que no plasma (STERN; JEDRZEJAS, 2006). Já a PH-20 humana apresenta dois pHs ótimos, $\mathrm{pH} 4,5$ e pH 7,5, referentes a duas isoformas, uma ligada à membrana e outra solúvel (MIO et al., 2001). Hialuronidases de tumores são mais ativas em pH entre 3,7 e 4,0 (MENZEL; FARR, 1998). Já as hialuronidases de diversas peçonhas apresentam faixa de $\mathrm{pH}$ ótimo entre 4,0 e 5,0 (CEVALLOS et al., 1992; FISZERSZAFARZ, 1984; IWANAGA; SUZUKI, 1979a, 1979b), sendo observado pH ótimo de 3,6 para a enzima de Apis mellifera (BRENDA, 2009).

A atividade hialuronidásica é $\mathrm{pH}$-dependente e a instabilidade frente a variações de $\mathrm{pH}$ é variável entre as espécies. Por exemplo, a hialuronidase testicular bovina tem $\mathrm{pH}$ ótimo de 4,0, mas mantém $70 \%$ de sua atividade máxima em $\mathrm{pH}$ 5,0 e é ativa também em $\mathrm{pH} 7,5$, enquanto a hialuronidase encontrada no plasma humano é ativa somente em pH abaixo de 5,3 (Wolf ${ }^{7}$ et al. apud MENZEL; FARR, 1998). Já a hialuronidase vítrea humana, em contraste com outras hialuronidases humanas, apresenta atividade significativa em $\mathrm{pH}$ neutro (Schwartz ${ }^{8}$ et al. apud MENZEL; FARR, 1998).

O pl também varia bastante, sendo normalmente básico para peçonhas. A hialuronidase da peçonha de Agkistrodon contortrix contortrix tem pl de 9,0 (KUDO; TU, 2001); as isoformas da hialuronidade da peçonha de Naja naja têm pl de 9,2 e 9,7 (BRENDA, 2009); já o esperma de Macaca sp. apresenta seis isoformas com pl variando de 5,1 a 6,0 (LI et al., 2002).

A massa molar das hialuronidases varia de 7.000 a 320.000 (ARONSON; DAVIDSON, 1967a, 1967b; BRENDA, 2009; BRUNISH; MOZERSKY, 1958; SILBERT; NAGAI; GROSS, 1965; TAM; CHAN, 1985; WRIGHT et al., 1977; ZANEVELD; POLAKOSKI; SCHUMACHER, 1973), sendo que peçonhas de

\footnotetext{
${ }^{7}$ WOLF, R. A. et al. The serum kinetics of bovine testicular hyaluronidase in dogs, rats and humans. Journal of Pharmacology and Experimental Therapeutics, Baltimore, v. 222, n. 2, p. 331-337, 1982.

${ }^{8}$ SCHWARTZ, D. M. et al. Human vitreous hyaluronidase: isolation and characterization. Current Eye Research, London, v. 15, n. 12, p. 1156-1162, 1996.
} 
serpentes, abelhas e escorpiões contêm hialuronidases com massa molar da ordem de 33.000 a 110.000. A hialuronidase de serpente Naja naja de 70 kDa é monomérica (GIRISH et al., 2004) e sua isoforma apresenta 54 kDa (BRENDA, 2009). A hialuronidase de Agkistrodon contortrix contortrix também é formada por uma única cadeia peptídica de aproximadamente 61 kDa (KUDO; TU, 2001).

\subsubsection{Moduladores da atividade hialuronidásica}

A atividade hialuronidásica é modulada por vários ativadores (adrenalina, histamina e fosfatases ácidas encontradas na próstata, fígado, rim, eritrócitos e plaquetas) e inibidores (antihistamínicos, salicilatos, heparina, dicumarina, vitamina C e flavonoides) ( $\mathrm{Li}^{9}$ et al. apud MENZEL; FARR, 1998).

Em estudos experimentais, a neutralização da atividade hialuronidásica por anticorpos monoclonais ou por extratos/componentes bioativos de plantas inibiu a lesão tecidual, a difusão e os efeitos letais de peçonhas ofídicas (GIRISH et al., 2004; GIRISH; KEMPARAJU, 2005, 2006; YINGPRASERTCHAI; BUNYASRISAWAT; RATANABANANGKOON, 2003). Os inibidores de hialuronidases podem ser proteínas, glicosaminoglicanas, polissacarídeos, ácidos graxos, lanostanóides, antibióticos, anti-nematoides, compostos orgânicos sintéticos, alcalóides, antioxidantes, polifenóis, flavonóides, terpenóides ou anti-inflamatórios (GIRISH et al., 2009). A inibição da hialuronidase aumentaria a eficiência da terapia antiofídica por retardar a difusão das toxinas e atenuar os efeitos adversos desta terapia, visto que uma menor dose seria capaz de neutralizar a peçonha (GIRISH; KEMPARAJU, 2011).

\subsubsection{Medicamentos contendo hialuronidase}

Terapeuticamente, as hialuronidases são usadas para acelerar a absorção e diminuir o desconforto causado pela injeção subcutânea ou intramuscular de fluidos, para promover a reabsorção de excessos de fluidos e extravasamento de sangue nos tecidos, e para aumentar a eficiência de anestésicos (MARTINDALE..., 1982). A coadministração de hialuronidase reduz efeitos adversos locais nos tecidos e

\footnotetext{
${ }^{9}$ LI, M. W. et al. Inhibition of monkey sperm hyaluronidase activity and heterologous cumulus penetration by flavonoids. Biology of Reproduction, New York, v. 56, n. 6, p. 1383-1389, 1997.
} 
aumenta a velocidade de absorção dos fluidos ao degradar o hialuronan, pois a enzima permite a difusão mais rápida do medicamento para o sítio-alvo e aumenta o contato do fluido com os vasos sanguíneos (DUNN et al., 2010). Desta forma, a hialuronidase melhora em até vinte vezes a taxa de infusão e a penetração de moléculas de até $200 \mathrm{~nm}$ de diâmetro (BOOKBINDER et al., 2006).

Nos casos de extravasamento de medicamentos intravenosos e infusões, costuma-se fazer injeção local de hialuronidases, entre outros procedimentos, para evitar sérias perdas de tecido frouxo e cicatrização ao redor de nervos, junções e tendões (MURPHY; GAULT, 1990).

Hialuronidases têm sido extensivamente usadas em muitas áreas tais como: ortopedia, cirurgia, oftalmologia, dermatologia, ginecologia, oncologia, entre outras (MENZEL; FARR, 1998). Estudos clínicos sugerem que o uso tópico ou sistêmico de hialuronidases como adjuvantes pode aumentar 0 índice terapêutico de medicamentos antineoplásicos e a difusão local de fármacos em tecidos e tumores (LOKESHWAR et al., 1996; OHYA; KANEKO, 1970; PODYMA et al., 1997; PRITCHARD et al., 1994).

Esta enzima é comercializada legalmente nos EUA desde 1948, aprovada para ser usada como adjuvante no espalhamento e dispersão de outros medicamentos injetáveis (DUNN et al., 2010).

Antes da introdução da hialuronidase recombinante humana purificada (rHuPH20 ou Hylenex), em 2005, todas as formulações aprovadas eram derivadas de extratos brutos impuros (menos de $1 \%$ de atividade enzimática por mg de proteína total) de tecido testicular ovino (Vitrase) ou bovino (Amphadase e Hydase). Esses extratos eram imunogênicos (BOOKBINDER et al., 2006), contaminados com proteases, imunoglobulinas e fatores que aumentam a permeabilidade capilar e podem aumentar as reações alérgicas mediadas por lgE (EBERHART; WEILER; ERIE, 2004; PILLWEIN et al., 1998; Williams ${ }^{10}$ apud BOOKBINDER et al., 2006). Devido à ocorrência de reações alérgicas e irritação da pele, foi descontinuado o uso de hialuronidase bovina (EBO et al., 2005). Já a hialuronidase de origem ovina é aprovada para o tratamento de hemorragia do vítreo e como adjuvante em procedimentos cirúrgicos oftálmicos, pois promove a liquefação vítrea pré e

\footnotetext{
${ }^{10}$ Williams, R.G. The effects of continuous local injection of hyaluronidase on skin and subcutaneous tissue in rats. Anatomical Record, Philadelphia, v. 122, n. 3, p. 349-361, 1955.
} 
peroperatória, reduzindo o tempo e aumentando a eficácia desses procedimentos (DUNN et al., 2010).

Até a introdução da hialuronidase recombinante humana, que eliminou qualquer risco de ocorrer reação alérgica ou doenças príon-relacionadas (DUNN et al., 2010), não havia qualquer produto disponível para uso clínico em hipodermóclise (PIRRELLO; CHEN; THOMAS, 2007). A hipodermóclise consiste na infusão de fluidos no tecido subcutâneo, como cuidado paliativo, em pacientes que apresentam difícil acesso endovenoso e necessitam de hidratação, acompanhada de analgesia e outros medicamentos, com lenta absorção (PEREIRA; RIBEIRO, 2006).

A hialuronidase pode ser adicionada à solução de hipodermóclise para facilitar a hidratação subcutânea e a infusão de medicamentos, pois, ao hidrolisar o hialuronan, diminui a viscosidade da matriz intersticial, causando um aumento na difusão e absorção de fluidos administrados subcutaneamente e diminuição do intumescimento no sítio de infusão (PIRRELLO; CHEN; THOMAS, 2007).

Esta enzima tem sido utilizada para melhorar a absorção de agentes radiopacos na urografia subcutânea e facilitar a remoção de aderências epidurais (fibrose epidural) no tratamento da dor crônica (DUNN et al., 2010). Seu uso também foi relatado na prevenção de lacerações perineais no parto normal (SCARABOTTO; RIESCO, 2008) e no tratamento tópico de fimose em associação com betametasona (FAVORITO et al., 2008).

Em cirurgias oftálmicas, hialuronan é frequentemente injetado para manter a cavidade orbital anterior intacta ou para proteger o endotélio da córnea durante o transplante, enquanto a administração concomitante de hialuronidase controla o aumento da pressão intraocular (FECHNER; WICHMANN, 1997). A enzima também é usada como uma alternativa ou como adjuvante para a vitrectomia convencional (HAROONI et al., 1998).

A hialuronidase atua também como um efetivo redutor de edema, sendo utilizada para dimuir o edema intersticial correlacionado ao acúmulo de hialuronan e água que ocorre na rejeição de órgãos transplantados (JOHNSSON et al., 1999). Pelo seu importante papel na redução de edema, a enzima tem sido utilizada em cirurgias plásticas, angiologia, como auxiliar no tratamento de microvarizes e após cirurgia coronariana. É utilizada na prevenção e no tratamento da lipoesclerose, também denominada lipodistrofia ou celulite (inflamação da derme e tecido 
subcutâneo) que ocorre na administração de insulina, antivirais, vincristina e outros medicamentos antineoplásicos.

A indústria farmacêutica brasileira Apsen comercializa: Postec® (hialuronidase $150 \mathrm{UTR} / \mathrm{g}$ + valerato de betametasona 2,5 mg/g), para tratamento de fimose; Xilodase® (hialuronidase $50 \mathrm{UTR} / \mathrm{g}$ + lidocaína $50 \mathrm{mg} / \mathrm{g}$ + sulfato de neomicina $5 \mathrm{mg} / \mathrm{g}$ ), para hemorroidas; Oto-xilodase® (hialuronidase $100 \mathrm{UTR} / \mathrm{mL}+$ lidocaína $50 \mathrm{mg} / \mathrm{mL}$ + sulfato de neomicina $5 \mathrm{mg} / \mathrm{mL}$ ), para otite média; Hyalozima (400 UTR/mL e $4.000 \mathrm{UTR} / \mathrm{mL}$ ), para difusão de anestésicos e reabsorção de exsudatos e transudatos; e Hyalozima creme (1.330 UTR/g), para edemas locais ou lipodistrofia. Em decorrência da associação da enzima ocorre diminuição dos efeitos adversos, do tempo de resolução, e, consequentemente, do custo total do tratamento (BULAS DE MEDICAMENTOS NA INTERNET, 2010a, 2010b).

\subsubsection{Correlação estrutura e função das hialuronidases}

No total, até o presente momento, há 40 estruturas tridimensionais de hialuronidases depositadas no PDB (Protein data bank), sendo 85\% delas resolvidas para enzimas de bactérias. Há apenas seis estruturas tridimensionais depositadas para hialuronidases de eucariotos (EC 3.2.1.35): uma da Hyal-1 de Homo sapiens (2PE4), quatro da peçonha de Apis mellifera (1FCQ, 1FCV, 1FCU, 2J88) e uma do alérgeno recombinante Ves v2 de Vespula vulgaris (2ATM).

A hialuronidase nativa de abelha possui $30 \%$ de identidade com a $\mathrm{PH}-20$ e a Hyal-1 humanas sobre uma região de 363 aminoácidos (MARKOVIĆ-HOUSLEY et al., 2000). Os resíduos conservados nas hialuronidases humana Hyal-1, Hyal-2, Hyal-3, Hyal-4 e PH-20 (hPH-20) e na hialuronidase bovina $\mathrm{PH}-20$ (bPH-20) comparados com a hialuronidase da peçonha de abelha (bvHyal), estão apresentados na Figura 3. 


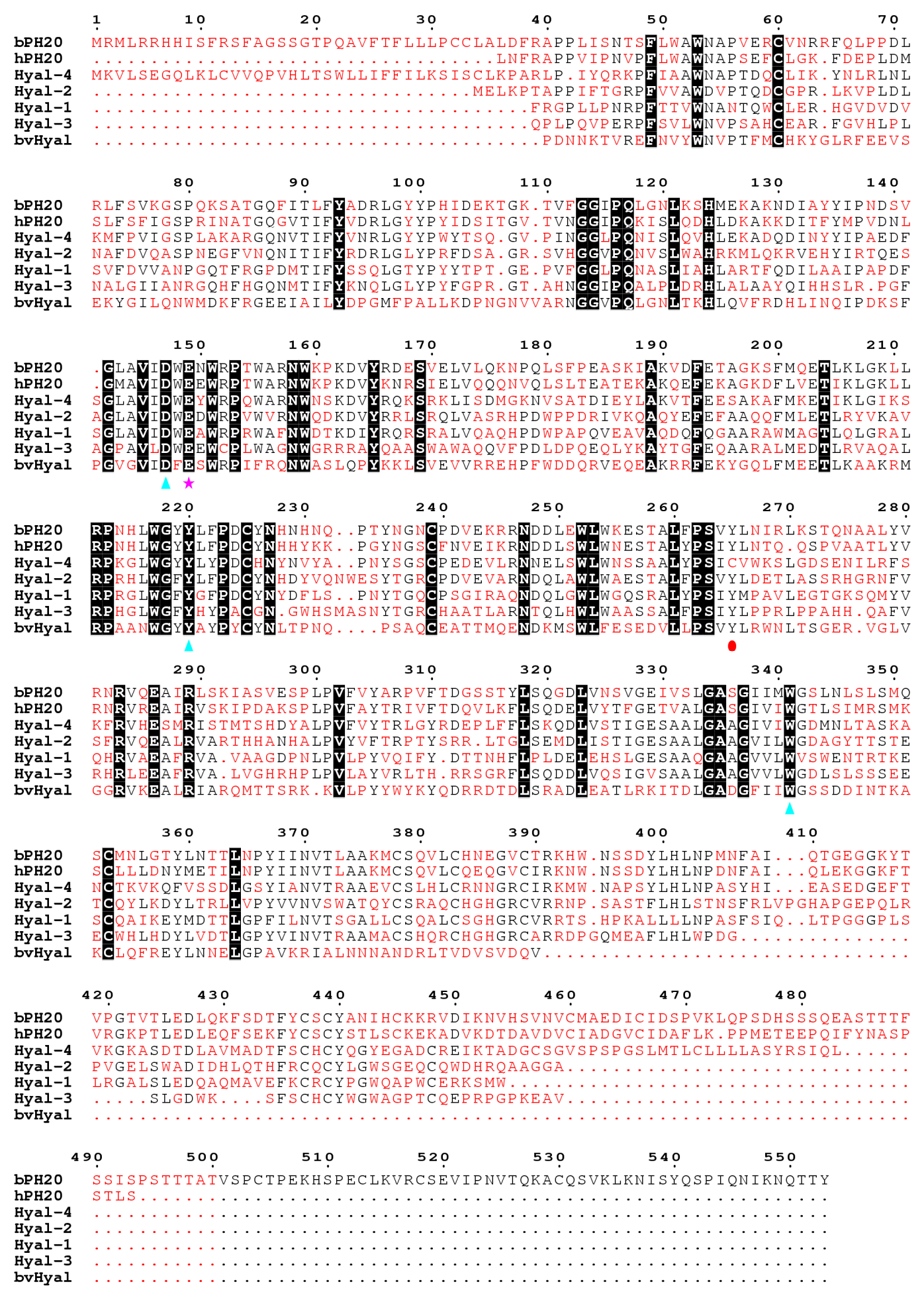

Figura 3. Alinhamento múltiplo realizado no MultAlin entre hialuronidase de Apis mellifera (bvHyal Uniprot ID Q08169), hialuronidase bovina (bPH20 Uniprot ID Q2YDK3) e as hialuronidases humana hPH20 (Uniprot ID P38567), Hyal-4 (Uniprot ID Q2M3T9), Hyal-2 (Uniprot ID Q12891), Hyal-1 (Uniprot ID Q12794) e Hyal-3 (Uniprot ID 043820). As áreas destacadas em preto delimitam as regiões conservadas (alto consenso) e os aminoácidos em vermelho indicam os resíduos de baixo consenso. A estrela cor-de-rosa indica o resíduo (Glu) que participa do mecanismo catalítico. O triângulo azul indica os resíduos conservados entre as hialuronidases de vertebrados envolvidos no processo catalítico e essenciais para o posicionamento do grupo acetamido da carbonila do substrato para a catálise (STERN; JEDRZEJAS, 2006). O círculo vermelho destaca o resíduo responsável pela especificidade a condroitina (cisteína) ou hialuronan (tirosina) (STERN; JEDRZEJAS, 2006). 
As hialuronidases humana Hyal-1, Hyal-2, Hyal-3, Hyal-4 e PH-20 (hPH-20) e a bovina $\mathrm{PH}-20$ (bPH-20) e a da peçonha de abelha (bvHyal) (Fig. 3) conservam todos os resíduos catalíticos, posicionais e estruturais, que caracterizam esta classe de hidrolases. O resíduo Glu149 participa do mecanismo catalítico. Os resíduos Asp147, Tyr220, Trp341 são essenciais para o posicionamento do grupo acetamido da carbonila do substrato para a catálise (STERN; JEDRZEJAS, 2006). O Tyr265 é responsável pela especificidade para hialuronan e a substituição por Cys265 é responsável pela função condroitinase (STERN; JEDRZEJAS, 2006).

A Hyal-1 de 57 kDa compreende uma cadeia polipeptídica única de 49 kDa com 8 kDa adicionados por glicosilação pós-traducional (STERN; JEDRZEJAS, 2006) e está relacionada com angiogênese e crescimento tumoral (CHAO et al., 2007). A Hyal-1 é a única hialuronidase de mamífero que teve sua estrutura terciária resolvida, a qual foi depositada no PDB sob código 2PE4 (Fig. 4).

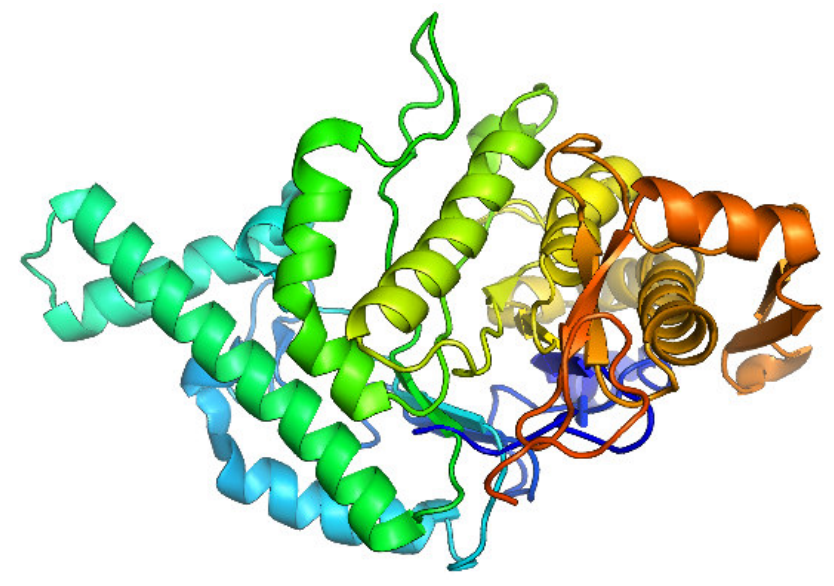

Figura 4. Estrutura tridimensional da hialuronidase Hyal-1 de Homo sapiens. PDB: 2PE4 (CHAO et al., 2007).

As hialuronidases Hyal-1, de vespa e de abelha pertencem à família 56 das hidrolases e suas estruturas apresentam enovelamento do tipo barril-TIM distorcido $(\beta / \alpha)_{n}(n=8$ para a hialuronidase de abelha e Hyal-1, $n=7$ para a de vespa). A estrutura da Hyal-1 é estabilizada por cinco pontes dissulfeto (CHAO et al., 2007), enquanto as de abelha e de vespa são estabilizadas por duas pontes dissulfeto (MARKOVIĆ-HOUSLEY et al., 2000; SKOV et al., 2006). A hialuronidase de abelha possui apenas um sítio de N-glicosilação, apesar de sua estrutura primária apresentar quatro possíveis sítios (MARKOVIĆ-HOUSLEY et al., 2000), enquanto a de vespa possui três de cinco possíveis sítios de N-glicosilação (SKOV et al., 2006). 
Uma fenda de aproximadamente $30 \AA$ x $10 \AA$ é observada na superfície da hialuronidase de abelha, onde são encontrados resíduos aromáticos e hidrofóbicos (STERN; CSÓKA, 2000) que participam da ligação ao substrato e catálise (STERN; JEDRZEJAS, 2006). Esta fenda é suficientemente grande, para acomodar um hexassacarídeo, o menor oligômero que pode ser hidrolisado por hialuronoglicosaminidases (MARKOVIĆ-HOUSLEY et al., 2000).

O mecanismo hidrolítico das hialuronidases pertencentes à família 56 das hidrolases envolve um ácido glutâmico (Glu), o único resíduo catalítico da enzima, como doador de prótons e o grupo carbonila da N-acetil-D-glicosamina do hialuronan como nucleófilo (MARKOVIĆ-HOUSLEY et al., 2000; SKOV et al., 2006; CHAO et al., 2007). Portanto, esse mecanismo catalítico ácido-base opera via substratoassistido, ou seja, o substrato participa do mecanismo de ação da sua própria catálise, como representado na Figura 5.

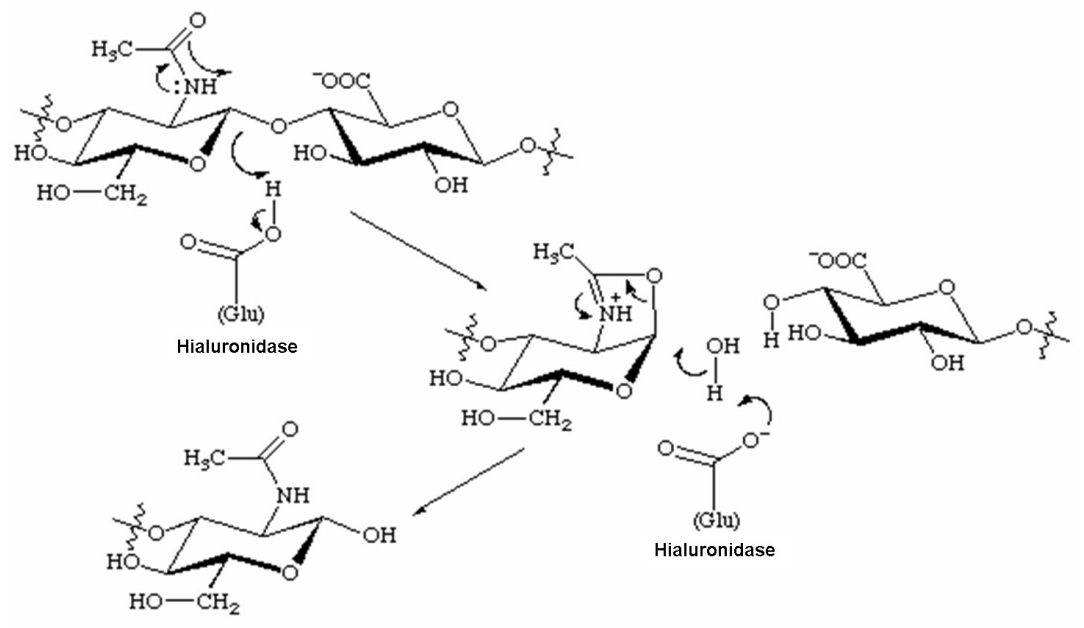

Figura 5. Representação do mecanismo de hidrólise enzimática das hialuronidases (JEDRZEJAS; STERN, 2005).

Pelo fato de a hialuronidase desempenhar um papel importante na ação da peçonha e estar envolvida em processos fisiológicos e patológicos, além de possuir inúmeras aplicações terapêuticas, é importante caracteriza-la química e estruturalmente, pois pode servir de modelo para o desenvolvimento de antivenenos e de novos adjuvantes de medicamentos. Dada a importância biológica e a escassez de dados sobre hialuronidases de peçonhas, este trabalho tem a finalidade de apresentar a caracterização funcional e estrutural da enzima isolada da peçonha de serpente Crotalus durissus terrificus. 
2. OBJETIVOS 
Os objetivos deste trabalho foram o isolamento e a caracterização funcional e estrutural da hialuronidase presente na peçonha de serpente Crotalus durissus terrificus.

Para isto, foram realizadas as seguintes etapas:

- Isolamento da hialuronidase da peçonha de Crotalus durissus terrificus pela associação de métodos cromatográficos;

- Caracterização: determinação da massa molar, do ponto isoelétrico, da atividade enzimática para diferentes substratos (hialuronan e sulfatos de condroitina A, B e C), atividade específica, estabilidade em função do $\mathrm{pH}$, temperatura e sais e avaliação do grau de pureza;

- Realização de testes biológicos para avaliar a relevância da hialuronidase no envenenamento como "fator de espalhamento" através de ensaios de atividade edematogênica da $\mathrm{PLA}_{2}$ e da crotoxina de Crotalus durissus terrificus.

- Determinação da sequência amino-terminal inicial da hialuronidase isolada.

- Ensaios cristalográficos preliminares para obter cristais a serem submetidos à difração de raios- $X$ na tentativa de resolver a estrutura cristalina da hialuronidase. 
3. MATERIAL E MÉTODOS 


\subsection{Material e Animais}

\subsubsection{Reagentes, solventes, soluções e matérias-primas}

1. Acetato de sódio - J.T. Baker;

2. Acetonitrila grau CLAE - Merck;

3. Ácido trifluoroacético (TFA) - Sigma;

4. Hialuronan (ácido hialurônico) - Sigma;

5. Reagentes utilizados no sequenciador de proteínas - Wako;

6. Stains-all-Sigma;

7. Sulfato de condroitina A (ou condroitina-4-sulfato ou C4S) - Sigma;

8. Sulfato de condroitina B (ou sulfato de dermatana ou beta-heparina) - Sigma;

9. Sulfato de condroitina C (ou condroitina-6-sulfato ou C4S) - Sigma;

Os demais reagentes utilizados foram todos de grau analítico.

\subsubsection{Equipamentos e Acessórios}

1. Agitador de tubos modelo AP56 - Phoenix;

2. Agitador magnético com aquecimento - Quimis;

3. Balança analítica - Ohaus;

4. Balança semi-analítica eletrônica de precisão modelo BG4400 - Gehaka;

5. Banho-maria modelo 100 - FANEM;

6. Bomba à vácuo (compressor/aspirador) modelo 089 - FANEM;

7. Centrífuga refrigerada modelo 5415R - Eppendorf;

8. Centrífuga Biofuge Primo R-Sorvall;

9. Espectrofotômetro modelo U-2001 - Hitachi;

10. Fonte de eletroforese EPS 3500XL - Pharmacia Biotech/GE;

11. Leitor de microplacas Sunrise - Tecan;

12. Liofilizador Virtis - SP;

13. Sequenciador Automático de Proteínas, modelo PPSQ-33A - Shimadzu, com detector UV-Vis modelo SPD-20A e cromatógrafo líquido modelo LC-20AT; 
14. Sistema de cromatografia líquida rápida de proteínas (FPLC) Äkta Purifier UPC-10 - GE Healthcare, com duas bombas de injeção de solvente, controle automático de vazão, detector UV-visível e condutivímetro;

15. Sistema de focalização isoelétrica Multiphor II com banho termostatizado Pharmacia Biotech/GE;

16. Sistema purificador de água ultrapura modelo Synergy UV - Millipore;

17. Vidraria em geral.

\subsubsection{Peçonha}

A peçonha bruta de serpente Crotalus durissus terrificus (CdtV) foi extraída e fornecida pelo Biotério Central da Universidade de São Paulo, campus de Ribeirão Preto, dessecada à vácuo a temperatura ambiente e conservada a $-20^{\circ} \mathrm{C}$. O Anexo A apresenta o Certificado de Regularidade do Biotério Central emitido pelo IBAMA.

\subsubsection{Animais}

Foram utilizados camundongos machos Swiss (28-32 g) adquiridos do Biotério Central da Universidade de São Paulo, campus de Ribeirão Preto. O Anexo B apresenta o Certificado de aprovação pela Comissão de Ética no Uso de Animais (CEUA) do campus de Ribeirão Peto (Protocolo $n^{\circ}$ 08.1.1038.53.1). 


\subsection{Métodos}

\subsubsection{Purificação}

\subsubsection{Cromatografia de troca catiônica em CMC-52 da peçonha de Crotalus durissus terrificus}

Cerca de 1,0 $\mathrm{g}$ da peçonha bruta dessecada de Crotalus durissus terrificus foi disperso em 50,0 mL de tampão acetato de sódio 0,05 mol/L, $\mathrm{pH} 5,5$ (que foi o $\mathrm{pH}$ ótimo para a atividade enzimática determinado nos ensaios). A dispersão foi centrifugada a $8.000 \mathrm{xg}$ por 15 minutos a $4{ }^{\circ} \mathrm{C}$. O sobrenadante foi aplicado, utilizando Superloop de $50 \mathrm{~mL}$ (GE), em uma coluna de vidro (1 x $40 \mathrm{~cm}, \mathrm{GE}$ ) empacotada com resina carboximetilcelulose-52 (CMC-52) (Whatman/GE) equilibrada com o mesmo tampão. As proteínas foram eluídas em tampão acetato de sódio 0,05 mol/L, pH 5,5, com gradiente descontínuo até $1 \mathrm{~mol} / \mathrm{L}$ de $\mathrm{NaCl}$ no mesmo tampão, sob vazão de $0,5 \mathrm{~mL} / \mathrm{min}$ no sistema FPLC Äkta Purifier UPC10 (GE). Frações de 2,0 $\mathrm{mL}$ foram coletadas e a absorbância foi determinada automaticamente em $280 \mathrm{~nm}$.

\subsubsection{Filtração em gel de Sephacryl S-100}

As frações com atividade hialuronidásica obtidos da cromatografia de troca catiônica foram reunidos e concentrados em membrana de celulose regenerada Ultracell YM de 30 kDa (Millipore) através de sistema de diafiltração Amicon® (Millipore) e aplicados na coluna de gel filtração HiPrep Sephacryl S-100 (1,6 x 60 cm, da GE), utilizando como fase móvel tampão acetato de sódio 0,05 mol/L, contendo $\mathrm{NaCl} 0,15 \mathrm{~mol} / \mathrm{L}, \mathrm{pH}$ 5,5. A filtração molecular foi realizada no sistema FPLC Äkta Purifier UPC10 (GE). Frações de 1,2 mL foram coletadas sob vazão de $0,5 \mathrm{~mL} / \mathrm{min}$. 


\subsubsection{Cromatografia de interação hidrofóbica em Phenyl-Sepharose}

As frações com atividade hialuronidásica obtidas a partir da utilização de cromatografia por filtração em gel foram reunidas e concentradas por ultracentrifugação em membrana de $30 \mathrm{kDa}$. À amostra concentrada foi adicionado $\mathrm{NaCl}$ até atingir a molaridade de 1,0 mol/L. Esta amostra foi aplicada em duas colunas HiTrap Phenyl-Sepharose HP (1 mL, da GE), conectadas em série, equilibradas com tampão acetato de sódio 0,05 mol/L, $\mathrm{pH} 5,5$, na presença de $\mathrm{NaCl}$ $1,0 \mathrm{~mol} / \mathrm{L}$. As proteínas foram eluídas no sistema FPLC Äkta Purifier UPC10 (GE) com gradiente de concentração decrescente, variando de $1,0 \mathrm{~mol} / \mathrm{L}$ até 0 a concentração de $\mathrm{NaCl}$ no tampão. Frações de $1 \mathrm{~mL}$ foram coletadas sob vazão de 1 $\mathrm{mL} / \mathrm{min}$ e a absorbância foi determinada automaticamente em $280 \mathrm{~nm}$.

\subsubsection{Cromatografia de fase reversa em coluna $\mathrm{C} 4$}

As frações com atividade hialuronidásica obtidas a partir da utilização de cromatografia por interação hidrofóbica em Phenyl-Sepharose foram combinadas e concentradas em membrana de $10 \mathrm{kDa}$, através de sistema de ultrafiltração Ultracell YM-4 (Millipore) até aproximadamente $200 \mu \mathrm{L}$. A amostra foi então diluída em TFA $0,1 \%$ e submetida à cromatografia líquida rápida de proteínas (FPLC) em coluna de fase reversa C4 (5 $\mu \mathrm{m}, 0,46 \times 25 \mathrm{~cm}$, da Shodex). Para a eluição dos componentes da amostra foi utilizado gradiente descontínuo de concentração até $100 \%$ da solução B (acetonitrila 60\% em TFA 0,1\%), no sistema FPLC Äkta Purifier UPC10 (GE). Frações de $1,0 \mathrm{~mL}$ foram coletadas sob vazão de $0,8 \mathrm{~mL} / \mathrm{min}$. Os picos correspondentes às proteínas puras foram congelados a $-80{ }^{\circ} \mathrm{C}$, liofilizados e armazenados a $-20^{\circ} \mathrm{C}$ para ensaios posteriores.

O fluxograma das etapas de extração e purificação da peçonha de Crotalus durissus terrificus para isolamento da hialuronidase CdtHya1 está apresentado na Figura 6. 


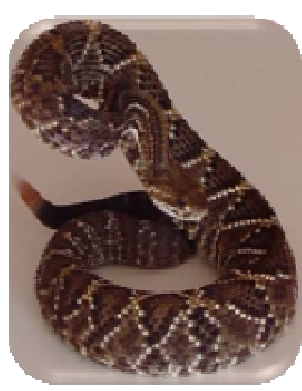

C.d. terrificus

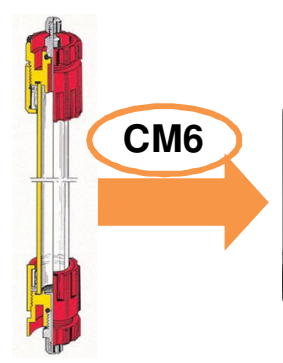

CMC-52

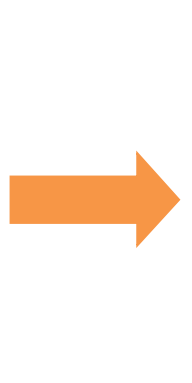

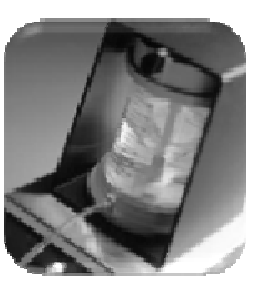

Concentrar

$1 \times 40 \mathrm{~cm}$

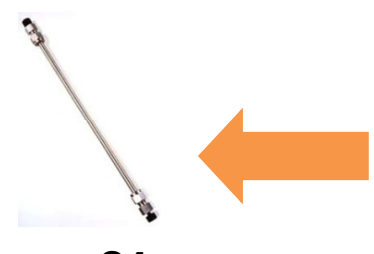

C4

$0,46 \times 25 \mathrm{~cm}$

1) Dessecar

2) Dispersar em tampão

3) Centrifugar

4) Separar sobrenadante

5) Purificar

$$
\text { peçonha }
$$
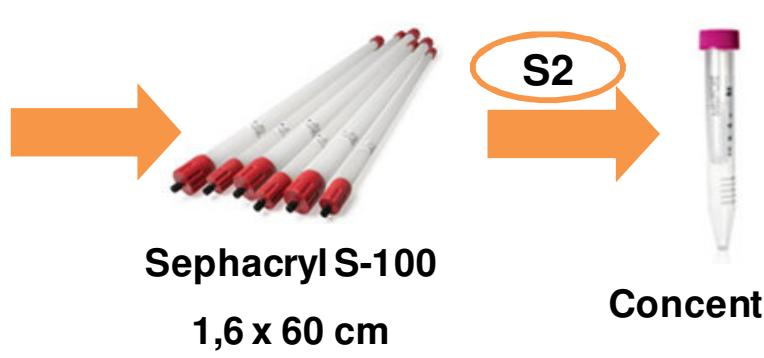

Concentrar

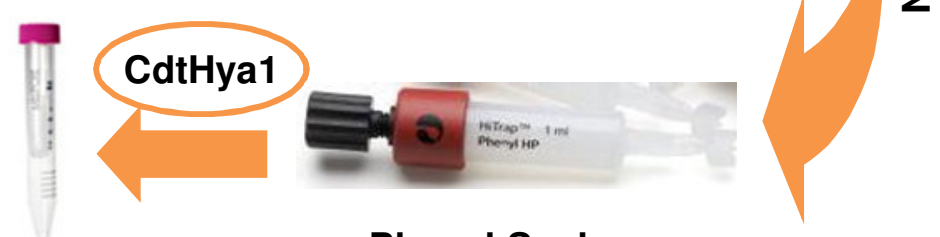

Phenyl-Sepharose

$1 \mathrm{~mL}$ (2 em série)

Figura 6. Fluxograma das etapas de extração e purificação da peçonha de Crotalus durissus terrificus para isolamento da hialuronidase CdtHya1. Fonte das fotos e imagens: Laboratório de Toxinas Animais (fotos das serpentes) e Google Imagens (colunas e concentradores). 


\subsubsection{Atividade hialuronidásica}

\subsubsection{Eletroforese em gel de poliacrilamida com agente desnaturante (SDS- PAGE) adicionado de hialuronan}

Foi realizada eletroforese em gel de poliacrilamida 10,0\% (m/v) com agente desnaturante dodecil sulfato de sódio (SDS) $0,1 \%$, hialuronan $(0,4 \mathrm{mg} / \mathrm{mL}$ ), TEMED 0,05\%, persulfato de amônio $0,05 \%$ e Tris- $\mathrm{HCl} 0,375 \mathrm{~mol} / \mathrm{L}$, $\mathrm{pH} 8,8$, segundo método descrito por Cevallos et al. (1992). Esse método modificou o protocolo descrito por Laemmli (1970) pela adição de hialuronan na matriz do gel durante a polimerização. As amostras foram dispersas em tampão de amostra de eletroforese contendo Tris$\mathrm{HCl} 0,1 \mathrm{~mol} / \mathrm{L}, \mathrm{pH} 6,8, \mathrm{SDS} 2 \%$, glicerol $10 \%$ e azul de bromofenol $1 \mathrm{mmol} / \mathrm{L}$. A eletroforese foi realizada a $90 \mathrm{~V}$, a temperatura ambiente, até que o corante azul de bromofenol presente no tampão da amostra atingisse a parte inferior do gel (cerca de 1 h 30 min). Após a eletroforese, o gel foi submetido a três lavagens de uma hora cada com concentrações decrescentes de Triton X-100, de 5\% a 0,05\%, em tampão fosfato de sódio $0,1 \mathrm{~mol} / \mathrm{L}, \mathrm{pH} 5,8$, contendo $\mathrm{NaCl}$ 0,15 mol/L. Em seguida, o gel foi equilibrado por 15 minutos no mesmo tampão sem Triton X-100 e, posteriormente, incubado neste tampão a $37{ }^{\circ} \mathrm{C}$, por 30 minutos. $\mathrm{O}$ gel foi então lavado com tampão Tris- $\mathrm{HCl}$ 0,015 mol/L, pH 7,9 e corado com Stains-all (Sigma) 0,1\% por no mínimo 4 horas e mantido no escuro até a imagem ser digitalizada. $O$ aparecimento de banda translúcida contra um fundo azul escuro indicou que o hialuronan foi clivado pela hialuronidase.

\subsubsection{Avaliação da atividade hialuronidásica por turbidimetria}

A atividade hialuronidásica foi determinada turbidimetricamente por modificações do método de Di Ferrante (1956) segundo Pukrittayakamee et al. (1988), mas adaptado para microplacas, como descrito a seguir.

Para determinar as condições ótimas para a atividade da hialuronidase, CdtV e hialuronan foram incubados por 15 minutos a diferentes pHs (2 a 11) e temperaturas $\left(0\right.$ a $\left.80{ }^{\circ} \mathrm{C}\right)$. 
As condições de ensaio que produziram atividade máxima foram escolhidas para os experimentos subsequentes.

Enzima e hialuronan foram misturados em microplaca de fundo chato de 96 poços e incubados por 15 minutos em banho-maria. A mistura de ensaio continha tampão acetato de sódio $200 \mathrm{mmol} / \mathrm{L}$, adicionado de $\mathrm{NaCl} 150 \mathrm{mmol} / \mathrm{L}, \mathrm{pH} \mathrm{5,5}$, $10 \mu \mathrm{g}$ de hialuronan $(0,5 \mathrm{mg} / \mathrm{mL}$ em tampão acetato) e enzima em tampão acetato em um volume final de $100 \mu \mathrm{L}$. O hialuronan não hidrolisado foi precipitado com $200 \mu \mathrm{L}$ de BCTA 2,5\% (m/v) dissolvido em hidróxido de sódio $2 \%(\mathrm{~m} / \mathrm{v})$ e a turbidez foi monitorada em $400 \mathrm{~nm}$ (dentro de 10 minutos) em leitor de microplacas Sunrise (Tecan). Foi feita uma curva de calibração variando o hialuronan de 0 a $10 \mu \mathrm{g}$.

A atividade hialuronidásica foi expressa como a porcentagem de hialuronan hidrolisado, considerando a absorbância do tubo ao qual não foi adicionada enzima como $100 \%$ de hialuronan remanescente $(10 \mu \mathrm{g})$, ou seja, $0 \%$ de hidrólise.

Uma unidade turbidimétrica reduzida (UTR) foi expressa como a quantidade de enzima necessária para hidrolisar $50 \%$ de hialuronan e a atividade específica corresponde ao número de unidades turbidimétricas reduzidas por mg de enzima. Pessini et al. (2001), baseando-se na relação obtida por Poh et al. (1992), puderam determinar que 0,153 UTR corresponde a 1 NFU (National Formulary Unit).

Os outros substratos analisados foram os sulfatos de condroitina A, B e C, de acordo com o procedimento descrito para o hialuronan, a fim de verificar a especificidade da hialuronidase de Crotalus durissus terrificus. Para cada substrato foi realizada uma curva de calibração sem adição de enzima.

Como controle, a peçonha solúvel ou a enzima pura foi adicionada no mesmo volume e na mesma concentração utilizados nos ensaios e a hialuronidase foi inativada com BCTA antes da adição de substrato, a fim de eliminar possíveis interferências de componentes da peçonha ou da enzima pura na presença ou ausência de turbidez de cada teste. Os resultados obtidos para o controle foram descontados dos valores obtidos para os respectivos ensaios nos quais a enzima permanecia ativa.

Como o ensaio de atividade por turbidimetria envolve a presença de íons e os mesmos podem alterar a turbidez da amostra, foram também realizados ensaios na presença de diferentes concentrações de $\mathrm{NaCl}$, denominado controle negativo, de forma a avaliar possíveis interferências nos ensaios de atividade hialuronidásica 
devido a presença de $\mathrm{NaCl}$ utilizado durante os passos cromatográficos. Foram realizados ensaios nas concentrações de $\mathrm{NaCl}$ (0-1 mol/L) no tampão acetato de sódio (0,2 mol/L, pH 5,5), sem a presença da enzima. A atividade hialuronidásica é avaliada pela redução da turbidez, portanto substâncias que reduzam a turbidez podem dar falsos resultados positivos.

O efeito de cátions foi determinado em tampão acetato de sódio 0,2 mol/L, $\mathrm{pH}$ 5,5, contendo diferentes sais a 0,2 mol/L ( $\mathrm{NaCl}, \mathrm{KCl}, \mathrm{MgCl}_{2}$ e $\mathrm{CaCl}_{2}$ ), para avaliar qual o melhor sal a ser utilizado nos processos de purificação que utilizam gradiente de concentração de sal para a eluição das proteínas. Busca-se determinar o sal que permita maior recuperação da enzima ativa e com menor interferência na determinação da atividade.

\subsubsection{Ensaios de cinética enzimática}

Os ensaios de cinética enzimática para hialuronidase foram realizados de acordo com o método descrito por Poh et al. (1992). A reação utilizada para o monitoramento da atividade hialuronidásica consistiu na adição de solução de hialuronidase $0,07 \mu \mathrm{g} / \mu \mathrm{L}$ em tampão acetato de sódio $50 \mathrm{mmol} / \mathrm{L}, \mathrm{pH} \mathrm{5,5}$, a uma solução contendo substrato em tampão acetato de sódio $200 \mathrm{mmol} / \mathrm{L}$ adicionado de cloreto de sódio $200 \mathrm{mmol} / \mathrm{L}, \mathrm{pH}$ 5,5.

Para o ensaio de hialuronan foram utilizados $6 \mu \mathrm{L}$ da enzima (2 UTR) e para os sulfatos de condroitina A, B e C utilizou-se $9 \mu \mathrm{L}$ da enzima (3 UTR). A concentração de hialuronan variou de 5,4 a $432 \mu \mathrm{g} / \mathrm{mL}$ e a dos sulfatos de condroitina A, B e C variou de 5 a $50 \mu \mathrm{g} / \mathrm{mL}$. A turbidez da reação foi monitorada pontualmente em $400 \mathrm{~nm}$ a temperatura ambiente $\left(25^{\circ} \mathrm{C}\right)$ utilizando leitor de microplacas Tecan Sunrise.

Para a determinação de $K_{m}$ e $V_{\max }$ a enzima foi incubada com o substrato, por 15 minutos, nas condições ótimas de $\mathrm{pH}$ e temperatura $\left(\mathrm{pH} 5,5\right.$ e $\left.37^{\circ} \mathrm{C}\right)$. A velocidade da reação foi expressa em $\mu \mathrm{g} / \mathrm{mL}$ de hialuronan hidrolisado por minuto.

A equação de Michaelis-Menten (a seguir) foi aplicada para os substratos utilizados: hialuronan e sulfatos de condroitina $A, B$ e $C$.

$$
V_{0}=\frac{V_{\text {máx }}[S]}{K m+[S]}
$$


Os valores de $K_{m}$ e $V_{\max }$ foram determinados a partir da curva cinética hiperbólica de Michaelis-Menten. Os dados foram ajustados com os respectivos erros padrão na equação de Michaelis-Menten, utilizando o software Prisma versão 6.0 (GraphPad Software Inc., San Diego, USA).

\subsubsection{Massa molar}

A massa molar da enzima foi estimada por SDS-PAGE (10\%) com hialuronan incorporado ao gel (CEVALLOS et al., 1992). As proteínas foram dispersas em tampão de amostra de eletroforese contendo Tris- $\mathrm{HCl} 0,1 \mathrm{~mol} / \mathrm{L}, \mathrm{pH} 6,8$, SDS $2 \%$, glicerol $10 \%$ e azul de bromofenol $1 \mathrm{mmol} / \mathrm{L}$. Para avaliar o perfil eletroforético da hialuronidase reduzida, a enzima foi desnaturada em banho de água fervente por 5 minutos em tampão de amostra de eletroforese adicionado de $\beta$-mercaptoetanol $5 \%$. Após a eletroforese, parte do gel foi corada com Stains-all (Sigma) para detecção da atividade hialuronidásica e a parte restante foi corada com PlusOne Coomassie Blue PhastGelTM R-350 (GE), como descrito no item 3.2.2.1.

\subsubsection{Focalização isoelétrica}

Utilizou-se o método descrito por Vesterberg (1972), com modificações, para determinar o ponto isoelétrico da hialuronidase pura. O gel foi preparado com poliacrilamida 5\%, glicerol 9,8\%, TEMED 0,4\%, persulfato de amônio 0,05\% e anfólitos pH 3 a 10 . Colocou-se o gel sobre uma placa cerâmica refrigerada a $4{ }^{\circ} \mathrm{C}$ e posicionou-se os eletrodos nas extremidades do gel. Para a pré-focalização foram programadas as condições de $1500 \mathrm{~V}, 30 \mathrm{~mA}$ e $10 \mathrm{~W}$. A amostra dispersa em água foi aplicada ao gel e a fonte de alta voltagem foi ajustada para $2000 \mathrm{~V}, 20 \mathrm{~mA}$ e $10 \mathrm{~W}$. Após a focalização, foram cortadas tiras de 0,5 a $1 \mathrm{~cm}$ das duas laterais do gel para determinar o gradiente de $\mathrm{pH}$. O gel contendo a amostra foi colocado em uma solução de ácido tricloroacético 10\% durante 15 minutos e, posteriormente, corado com PlusOne Coomassie Blue PhastGel ${ }^{T M} R-350$ (GE). 


\subsubsection{Identificação de glicoproteínas em gel desnaturante de poliacrilamida}

Foi realizada eletroforese em gel de poliacrilamida com agente desnaturante dodecil sulfato de sódio, como descrito por Laemmli (1970). Foi utilizado gel de concentração a $5 \%(\mathrm{~m} / \mathrm{V})$ e gel de resolução a $10 \%(\mathrm{~m} / \mathrm{V})$.

A eletroforese foi realizada a temperatura ambiente durante 1 hora $\mathrm{e}$ 20 minutos sob voltagem constante (90 V).

Após a eletroforese, o gel foi colocado em solução fixadora contendo ácido acético 10\% (V/V) e metanol 35\% (V/V) em água. Decorridas 2 horas, o gel foi lavado com água obtida por osmose reversa e deixado por 1 hora em solução aquosa, recém-preparada, contendo ácido periódico 0,7\% (m/ $/ \mathrm{v})$ e ácido acético 5\% (V/V). Em seguida, foi lavado com água obtida por osmose reversa e deixado duas vezes, durante 10 minutos cada, em solução de metabissulfito de sódio $0,2 \%(\mathrm{~m} / \mathrm{V})$ e ácido acético $5 \%(\mathrm{~V} / \mathrm{V})$. Posteriormente, o gel foi corado com ácido periódicoreagente de Schiff (PAS stain ou periodic acid-Schiff stain), com modificações do método descrito por Doerner e White (1990), e mantido no escuro por 2 horas. Logo depois, o gel foi lavado com água obtida por osmose reversa por várias vezes até que fosse definida a coloração rósea das bandas de glicoproteínas (cerca de 1 hora e 30 minutos) e a imagem foi digitalizada.

$O$ reagente de Schiff foi preparado da seguinte forma: $1 \mathrm{~g}$ de fucsina básica foi adicionada em $200 \mathrm{~mL}$ de água fervente. Decorridos 5 minutos de fervura, a solução foi resfriada a $50{ }^{\circ} \mathrm{C}$ em banho com gelo e filtrada em papel de filtro. Foram adicionados $20 \mathrm{~mL}$ de $\mathrm{HCl} 1 \mathrm{~N}$ ao filtrado e, após atingir a temperatura ambiente, acrescentou-se $1,7 \mathrm{~g}$ de metabissulfito de sódio. A solução foi armazenada em frasco de vidro âmbar e mantida no escuro, em temperatura ambiente, até o dia seguinte, quando foi utilizada para corar o gel.

\subsubsection{Atividade edematogênica}

As amostras $(40 \mu \mathrm{L})$ foram injetadas subcutaneamente na pata direita traseira de camundongos Swiss machos (28-32g) divididos em cinco grupos contendo cinco 
animais cada. O grupo controle foi injetado com tampão acetato de sódio 0,05 mol/L, $\mathrm{pH}$ 5,5, autoclavado e filtrado em membrana GV (Durapore®) em PVDF com poro de 0,22 $\mu \mathrm{m}$ (Millipore) em câmara de fluxo laminar. Os demais grupos foram injetados com:

1) Crotoxina de Crotalus durissus terrificus: $4 \mu \mathrm{g} / 40 \mu \mathrm{L}$ do tampão acetato.

2) Fosfolipase $A_{2}\left(P L A_{2}\right)$ de Crotalus durissus terrificus: $4 \mu \mathrm{g} / 40 \mu \mathrm{L}$ do tampão acetato.

3) Hialuronidase de Crotalus durissus terrificus: 32 UTR/40 $\mu \mathrm{L}$ do tampão acetato.

4) Crotoxina + Hialuronidase $(4 \mu \mathrm{g}+32 \mathrm{UTR}) / 40 \mu \mathrm{L}$ do tampão acetato.

5) $\mathrm{PLA}_{2}+$ Hialuronidase $(4 \mu \mathrm{g}+32 \mathrm{UTR}) / 40 \mu \mathrm{L}$ do tampão acetato.

As amostras foram preparadas em tubos de microcentrifugação estéreis e diluídas em tampão estéril. A mensuração da espessura das patas foi realizada previamente, antes da inoculação das soluções (tempo 0 min). Após a injeção de cada solução, a espessura da pata dos camundongos foi medida com um paquímetro de baixa pressão $0,01 \mathrm{~mm}$ (Mitutoyo Corporation) em diferentes intervalos de tempo (30,60, 120, 180, 240 e $330 \mathrm{~min})$.

A porcentagem de edema induzido foi calculada pela seguinte equação: $\%$ edema $=100 \times\left(e_{t}-e_{0}\right) / e_{0}$, em que $e_{t}$ corresponde à espessura da pata em determinado intervalo de tempo e $e_{i}$ à espessura da pata no tempo 0 min. Portanto, o dobro da espessura da pata no tempo 0 min foi considerado como $100 \%$ de edema.

Para cada grupo, o aumento da espessura da pata dos camundongos foi expresso em média da porcentagem de edema induzido \pm erro padrão médio.

A análise de variância estatística (ANOVA), seguida do teste de Tukey, com nível de significância de $1 \%(p<0,01)$, foi realizada através do software Prisma versão 6.0 (GraphPad Software Inc., San Diego, USA).

\subsubsection{Sequenciamento amino-terminal}

A sequência primária do $\mathrm{N}$-terminal da hialuronidase foi obtida pelo sequenciamento proteico através do método de degradação de Edman (EDMAN; BEGG, 1967), que consiste em três etapas: acoplamento, clivagem e conversão. 
Após os procedimentos de purificação, a proteína solúvel (10 pmol) foi aplicada diretamente em uma membrana de fibra de vidro (Wako, Japão).

O Sequenciador Automático de Proteínas da marca Shimadzu (Sistema PPSQ-33A), presente em nosso laboratório, procedeu à análise da estrutura primária da enzima. O aminoácido derivado da reação com o PITC (fenilisotiocianato) foi convertido a PTH-aa (feniltiohidantoína-aminoácido), que foi então separado por cromatografia líquida de alta eficiência (CLAE), utilizando coluna de fase reversa e gradiente isocrático. A quantificação e identificação dos resíduos foram realizadas através da comparação com os tempos de retenção do padrão de aminoácidos (25 pmol) aplicado antes do sequenciamento.

Cada resíduo particular é identificado baseando-se no aumento significativo de concentração em relação ao ciclo anterior seguido por uma diminuição do sinal durante os ciclos subsequentes.

\subsubsection{Análise in silico}

A sequência em aminoácidos obtida no sequenciamento amino-terminal da hialuronidase (item 3.2.7) foi usada para comparação com sequências depositadas nos bancos de dados FASTA (www.ebi.ac.uk/Tools/fasta33/index.html) e BLAST (http://blast.ncbi.nlm.nih.gov/ Blast.cgi). O alinhamento foi realizado no programa MultAlin (CORPET, 1988) e a figura criada no programa ESPript (GOUET et al., 1999).

\subsubsection{Estudos cristalográficos}

Os experimentos de cristalização foram realizados no Laboratório de Cristalografia de Proteínas (LCP-RP), sob orientação da Dra. Maria Cristina Nonato Costa, utilizando a técnica de cristalização de difusão de vapor em gota sentada, empregando o protocolo de matriz esparsa, ou fatorial incompleto (JANCARIK; KIM, 1991), implementada nos kits comerciais Crystal Screen e Crystal Screen II (Hampton Research) disponíveis para cristalização. 
A concentração de proteína foi determinada pelo método de Scopes (1974). Uma gota de $0,5 \mu \mathrm{L}$ de hialuronidase a $15 \mathrm{mg} / \mathrm{mL}$ foi misturada com o mesmo volume da solução de cristalização. O reservatório continha $500 \mu \mathrm{L}$ de solução de cristalização. A diferença de concentração entre a gota e o reservatório fez com que o sistema atingisse o equilíbrio por difusão, levando à formação de cristais.

Variações na concentração de polietinoglicol (PEG), pH, agentes tamponantes e de aditivos foram empregadas na tentativa de obter monocristais com estrutura organizada. Utilizou-se também o kit Seed Bead (HR2-310, da Hampton Research) para a técnica de microssemeadura. Os microcristais obtidos foram coletados e transferidos para o tubo de microcentrifugação contendo Seed Bead em $50 \mu \mathrm{L}$ da solução de cristalização e agitados em Vortex por 90 segundos. Uma gota de $0,5 \mu \mathrm{L}$ foi retirada e transferida para novas gotas contendo mais amostra proteica. 
4. RESULTADOS E DISCUSSÃO 


\subsection{Purificação}

\subsubsection{Perfil cromatográfico da CdtV em CMC-52}

A cromatografia da peçonha bruta de Crotalus durissus terrificus (CdtV) em CMC-52, realizada como descrito no item 3.2.1.1, apresentou o perfil cromatográfico abaixo (Fig. 7). As frações denominadas "CM5" e "CM6" apresentaram atividade hialuronidásica, como representado pelas barras cor-de-rosa da Figura 7, sendo, portanto, as frações onde a hialuronidase foi eluída.

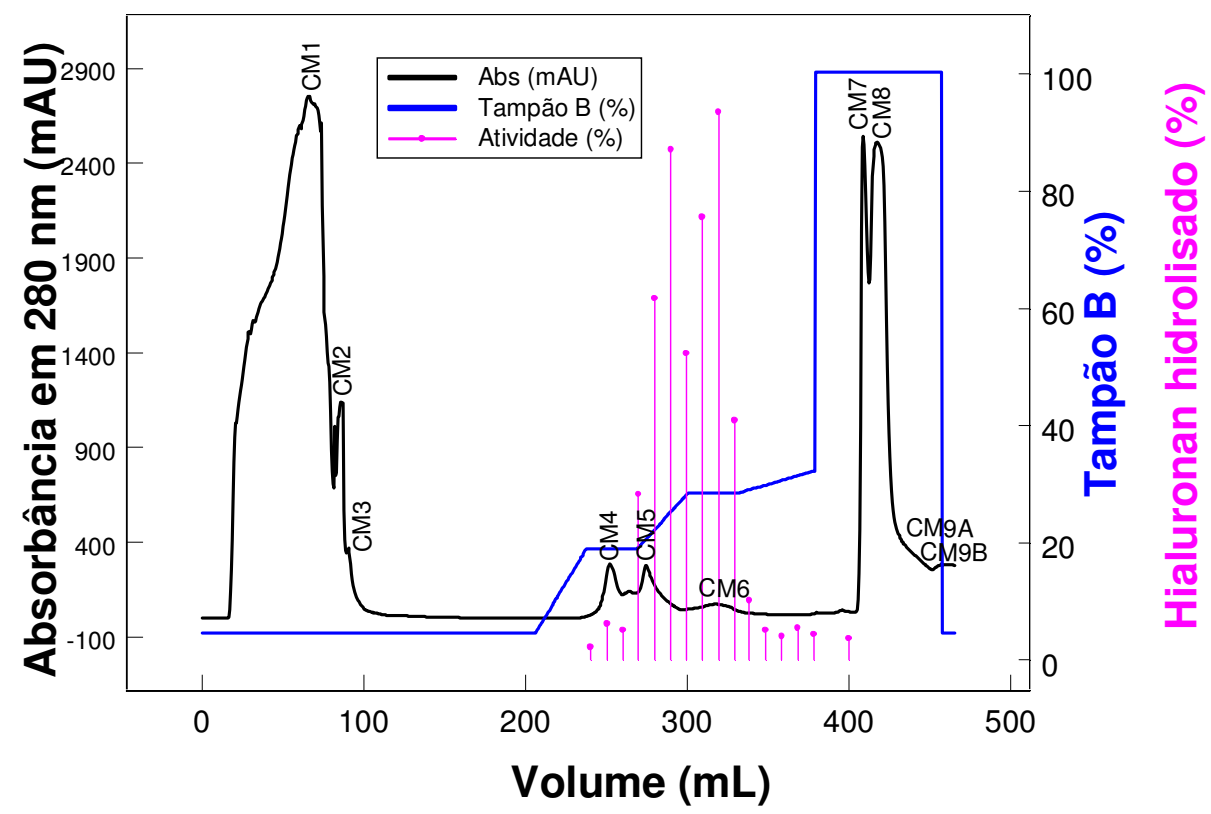

Figura 7. Perfil cromatográfico de CdtV em CMC-52. CdtV $(1 \mathrm{~g})$ foi dispersa em $50 \mathrm{~mL}$ de tampão acetato de sódio $0,05 \mathrm{~mol} / \mathrm{L}, \mathrm{pH} \mathrm{5,5}$. O fracionamento foi realizado em sistema FPLC Äkta Purifier UPC-10 com coluna de 1,0 x 40,0 cm empacotada com resina carboximetilcelulose-52, equilibrada com tampão $A$ (acetato de sódio $0,05 \mathrm{~mol} / \mathrm{L}, \mathrm{pH} 5,5$ ), sob vazão de $0,5 \mathrm{~mL} / \mathrm{min}$ e temperatura de $25^{\circ} \mathrm{C}$. A amostra foi eluída com gradiente descontínuo de concentração (0 a $\left.100 \%\right)$ de tampão B (acetato de sódio $0,05 \mathrm{~mol} / \mathrm{L}+\mathrm{NaCl} 1 \mathrm{~mol} / \mathrm{L}, \mathrm{pH} 5,5$ ), representado pela linha azul. Volume coletado por tubo: 2,0 mL. As linhas verticais cor-de-rosa representam a atividade hialuronidásica.

A primeira etapa de purificação foi realizada por cromatografia de troca catiônica fraca, em resina de CMC-52, em que o fracionamento é consequência da diferença na carga das proteínas. O procedimento mostrou-se adequado, 
apresentando uma boa resolução (Fig. 7) dos componentes da CdtV, como mostrado no gel da Figura 8.

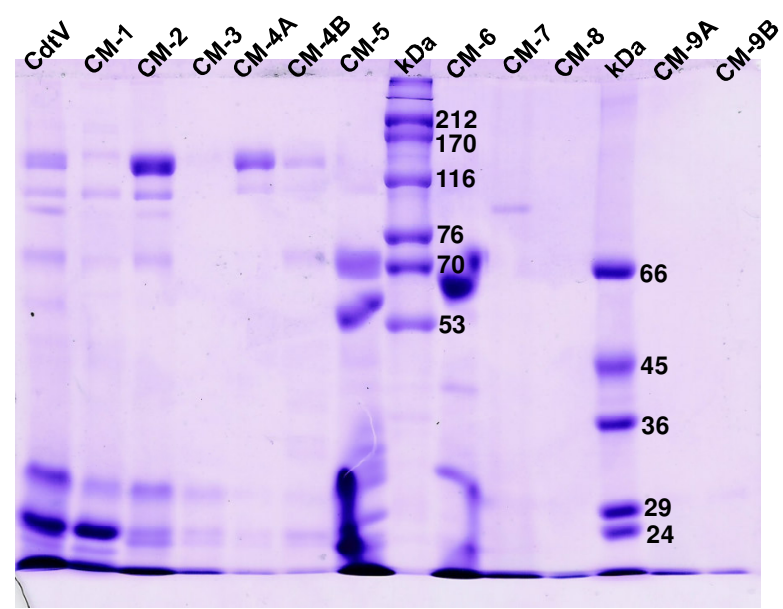

Figura 8. Perfil eletroforético das frações provenientes da purificação por cromatografia de troca iônica da peçonha bruta solúvel de Crotalus durissus terrificus em gel desnaturante de poliacrilamida a $10 \%$.

As frações CM5 e CM6 apresentaram atividade hialuronidásica no ensaio in vitro, como evidenciado pelas barras verticais cor-de-rosa (Fig. 7) e na SDS-PAGE com hialuronan incorporado ao gel (dados não apresentados). A fração CM6 foi escolhida para os ensaios de caracterização da hialuronidase por ser a fração em que a enzima eluiu em maior proporção e com maior atividade.

O mesmo protocolo de purificação foi realizado com a dispersão da peçonha em tampão adicionado do inibidor de metaloprotease EDTA (ácido etilenodiaminotetracético dissódico dihidratado) e inibidor de serinoprotease PMSF (fluoreto de fenilmetil sulfonila), para evitar degradação da enzima de interesse por proteases presentes na peçonha. Outro fato que corroborou para a utilização desses inibidores de protease no tampão para dispersar a peçonha foi o relato de Hurtado et al. (2007), demonstrando que a atividade da hialuronidase de Lachesis muta não foi afetada por PMSF $12 \mathrm{mmol} / \mathrm{L}$, nem por EDTA $12 \mathrm{mmol} / \mathrm{L}$. Estes resultados indicam que a hialuronidase não precisa de cátions divalentes para desempenhar sua atividade. No entanto, como não houve qualquer alteração no perfil de eluição, eletroforético ou de atividade entre os protocolos de purificação na presença ou ausência desses inibidores de protease (dados não apresentados), a adição desses inibidores de protease foi descontinuada. 


\subsubsection{Filtração em HiPrep 16/60 Sephacryl S-100 High Resolution}

Os tubos com atividade hialuronidásica correspondentes à fração CM6 da CMC-52 (Fig. 7) foram reunidos, concentrados e recromatografados em coluna HiPrep Sephacryl S-100 HR, como descrito no item 3.2.1.2. A fração denominada "S2" foi a que apresentou atividade hialuronidásica (Fig. 9).

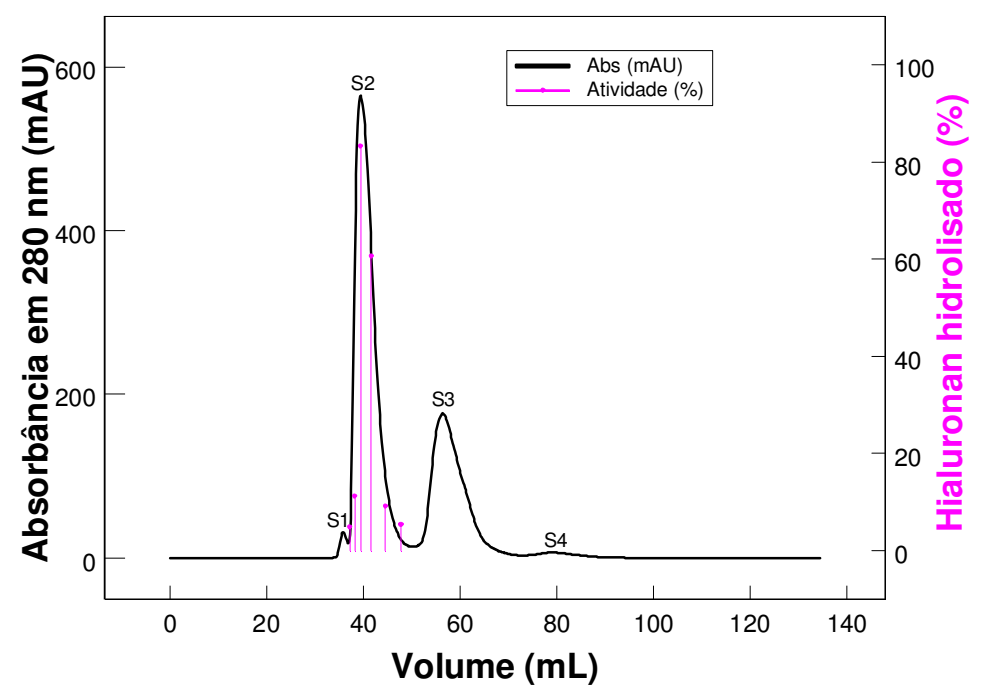

Figura 9. Perfil cromatográfico da fração "CM6" em HiPrep Sephacryl S-100 HR. O fracionamento foi realizado em sistema FPLC Äkta Purifier UPC-10 com coluna HiPrep Sephacryl S-100 HR (1,6 x 60,0 cm), equilibrada com tampão acetato de sódio 0,05 mol/L, $\mathrm{NaCl} 0,15 \mathrm{~mol} / \mathrm{L}$, $\mathrm{pH} 5,5$, sob vazão de $0,5 \mathrm{~mL} / \mathrm{min}$ e temperatura de $25^{\circ} \mathrm{C}$. A amostra $(1 \mathrm{~mL})$ foi eluída com o mesmo tampão e foi coletado $1,2 \mathrm{~mL}$ por tubo. As linhas verticais cor-de-rosa representam a atividade hialuronidásica.

A segunda etapa de purificação (Fig. 9) consistiu de uma filtração em gel em coluna HiPrep 16/60 Sephacryl S-100 High Resolution (GE). Essa coluna é capaz de separar proteínas com uma faixa de massa molar de 1.000 até 100.000 , segundo informações do manual da coluna.

Essa etapa cromatográfica mostrou-se satisfatória, uma vez que as proteínas de baixa massa molar foram separadas das de alta massa molar. A hialuronidase eluiu próximo ao volume morto da coluna (Fig. 9), devido à sua elevada massa molar, quando comparada com os contaminantes de baixa massa molar.

A fração CM6 foi utilizada nos ensaios de isolamento e caracterização da hialuronidase por ser a fração em que a enzima eluiu em maior proporção. Esta fração não foi misturada à fração $\mathrm{CM}$, pois esta última apresentava uma maior 
proporção de contaminantes (Fig. 8). Além disso, acredita-se que a hialuronidase da fração CM5 apresenta propriedades físico-químicas diferentes da hialuronidase eluída na fração CM6, visto que interagiram de forma diferenciada com a mesma resina.

\subsubsection{Cromatografia de interação hidrofóbica em Phenyl-Sepharose}

A fração hialuronidásica obtida da Sephacryl S-100, denominada S2 (Fig. 9), foi reunida, concentrada e recromatografada em coluna HiTrap Phenyl-Sepharose, como descrito no item 3.2.1.3. O pico 2 apresentou atividade hialuronidásica, como evidenciado pelas barras verticais cor-de-rosa (Fig. 10), e foi denominado CdtHya1.

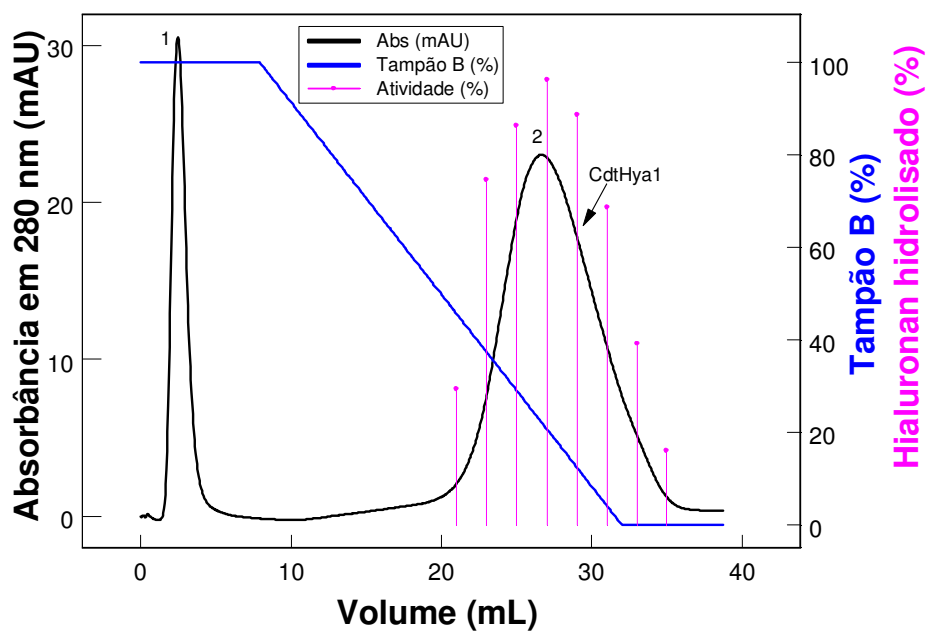

Figura 10. Perfil cromatográfico da fração "S2" em HiTrap Phenyl-Sepharose. O fracionamento foi realizado em sistema FPLC Äkta Purifier UPC-10 com duas colunas HiTrap Phenyl-Sepharose de $1 \mathrm{~mL}$ conectadas em série, equilibradas com tampão acetato de sódio 0,05 mol/L, pH 5,5, na presença de $\mathrm{NaCl} 1,0 \mathrm{~mol} / \mathrm{L}$, sob vazão de $1,0 \mathrm{~mL} / \mathrm{min}$ e temperatura de $25^{\circ} \mathrm{C}$. A amostra $(1 \mathrm{~mL})$ foi eluída com gradiente de concentração decrescente, variando de $1 \mathrm{~mol} / \mathrm{L}$ até 0 a concentração de cloreto de sódio no tampão, representado pela linha azul. Volume coletado por tubo: 1,0 mL. As linhas verticais cor-de-rosa representam a atividade hialuronidásica.

A terceira etapa da purificação foi realizada em uma coluna HiTrap PhenylSepharose, cujo fracionamento ocorre por meio da interação entre a região hidrofóbica (grupamento fenil) da resina e a região apolar da superfície da proteína (CHIARINI; VESSONI PENNA, 2003). Adicionou-se $\mathrm{NaCl} 1 \mathrm{~mol} / \mathrm{L}$ na amostra a ser purificada.Como consequência, alguns aminoácidos apolares da superfície da 
hialuronidase interagiram fortemente com a resina hidrofóbica e a enzima pura foi eluída pela diminuição da força iônica (Fig. 10).

Para verificar o grau de purificação da hialuronidase CdtHya1, foi realizada a SDS-PAGE a seguir (Fig. 11).

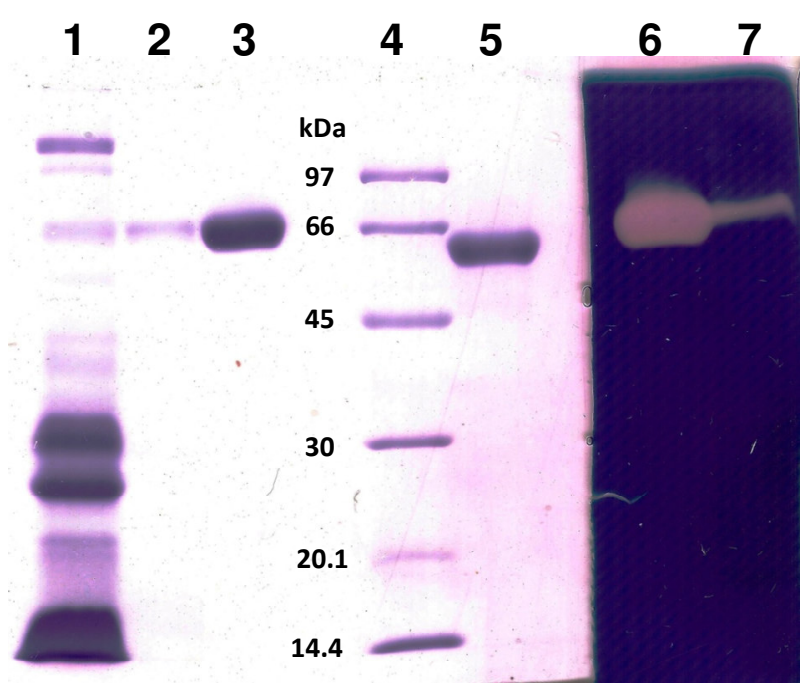

Figura 11. Perfil eletroforético das frações com atividade hialuronidásica em gel desnaturante de poliacrilamida a $10 \%$ com hialuronan. As frações aplicadas foram provenientes da peçonha solúvel e das cromatografias em CMC-52 e Phenyl-Sepharose. Poços 1 e 7: CdtV (34 $\mu \mathrm{g})$; 2: CM6 $(11 \mu \mathrm{g}) ; 3$ e 6: CdtHya1 não reduzida $(5 \mu \mathrm{g}) ; 4$ : Padrão de massa molar (GE cód. 17-0446-01); 5: CdtHya1 reduzida $(5 \mu \mathrm{g})$. Após a eletroforese, o gel foi corado com PlusOne Coomassie Blue PhastGel ${ }^{T M}$ R-350 (GE) (poços 1 a 5) e com Stains-all (Sigma) (poços 6 e 7) para determinação da atividade hialuronidásica.

O protocolo para purificação da hialuronidase de Crotalus durissus terrificus mostrou-se eficiente no isolamento de hialuronidase com alto grau de pureza, como fica evidente pelo SDS-PAGE da CdtHya1, que apresentou banda eletroforética única em condições redutoras e não redutoras (Fig. 11). A hialuronidase CdtHya1 pura (poço 3) foi utilizada nos ensaios subsequentes.

Entre as amostras aplicadas no gel da Figura 11, apenas a hialuronidase CdtHya1 aplicada no poço 5 foi adicionada de $\beta$-mercaptoetanol e fervida. Nestas condições, a hialuronidase CdtHya1 (poço 5) apresenta uma migração ligeiramente maior quando comparada à amostra sem $\beta$-mercaptoetanol (poço 3). Isso porque o $\beta$-mercaptoetanol é um agente redutor que causa o rompimento de pontes dissulfeto presentes na proteína. Esse rompimento pode ter alterado a conformação da enzima, facilitando a penetração da mesma no poro do gel e acarretando uma maior 
migração da proteína. A hialuronidase de Crotalus durissus terrificus foi inativada pela adição de $\beta$-mercaptoetanol, mesmo sem fervura (dados não apresentados). Há relatos de que a presença de agente redutor ou a fervura da amostra inativa irreversivelmente a hialuronidase (CEVALLOS et al., 1992; LI et al., 2002). Li et al. (2002) também observaram que a redução de ligações dissulfeto da hialuronidase $\mathrm{PH}-20$ de macaco com mercaptoetanol ou ditiotreitol resultou na perda de atividade da enzima e na diferente migração da banda proteica, cuja massa molar foi estimada entre 64 e 67 kDa. Portanto, a atividade da PH-20 é dependente das características estruturais estabelecidas por ligações dissulfeto.

Os poços 6 e 7 da Figura 11 mostram uma banda translúcida, correspondente à migração da hialuronidase. A hialuronidase foi revelada após a incubação desta parte do gel em Triton X-100 para remover o SDS do gel, restaurando a atividade enzimática in situ, como descrito por Cevallos et al. (1992). O corante utilizado neste ensaio (Stains-all) cora o hialuronan presente na matriz do gel e a ausência de cor indica que o hialuronan foi clivado pela enzima. Portanto, esta eletroforese confirmou que CdtV e CdtHya1 apresentam atividade hialuronidásica.

Esse método permite a detecção de 0,025 unidade turbidimétrica reduzida (UTR) de atividade hialuronidásica se o gel for incubado por 2 horas a $37{ }^{\circ} \mathrm{C}$. A sensibilidade pode ser aumentada dez vezes, sem perda de qualidade dos resultados, se o gel for incubado por 20 horas nas condições ótimas para a atividade (Cevallos et al., 1992). Neste ensaio, o gel da Figura 11 foi incubado por apenas 30 minutos a $37^{\circ} \mathrm{C}$, indicando que a enzima presente na peçonha de Crotalus durissus terrificus é bastante ativa.

As massas molares do padrão aplicado no poço 4 do gel da Figura 11 foram utilizadas na confecção da curva de calibração relacionando o log da massa molar versus distância de migração (Fig. 12), para determinar a massa molar da hialuronidase CdtHya1 não reduzida e reduzida (Fig. 11, poços 3 e 5, respectivamente). 


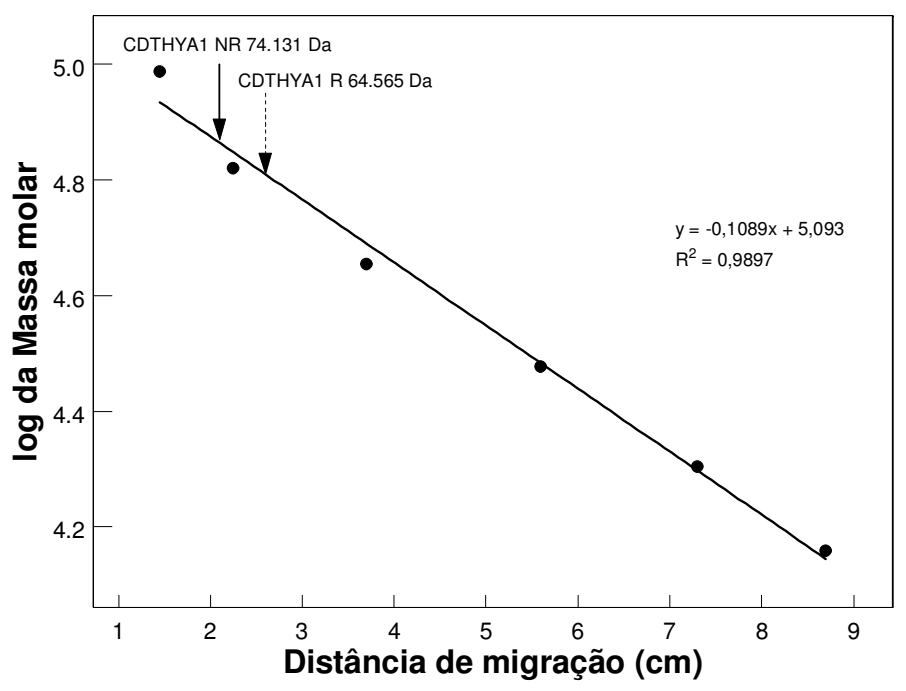

Figura 12. Curva de calibração para determinação da massa molar de proteínas. A curva foi traçada com os dados do log da massa molar do padrão aplicado no poço 4 da Figura 11 versus distância de migração $(\mathrm{cm})$. A hialuronidase CdtHya1 não reduzida aplicada no poço 3 da Figura 11 apresentou migração de 2,1 cm (massa molar calculada: 74,1 kDa), indicada por uma seta preta com linha contínua. A banda da hialuronidase sob condições redutoras aplicada no poço 5 apresentou migração de 2,6 cm (massa molar calculada: 64,5 kDa), indicada por uma seta preta com linha tracejada.

A banda proteica observada no poço 5 do gel da Figura 11 é a hialuronidase CdtHya1 e sua massa molar relativa foi estimada por SDS-PAGE através da curva de calibração (Fig. 12) em aproximadamente $64,5 \mathrm{kDa}$, sob condições redutoras (poço 5 da Fig. 11), e 74,1 kDa em condições não redutoras (poço 3 da Fig. 11). Isto é um indicativo de que a hialuronidase CdtHya1 é, provavelmente, um monômero, como a maioria das hialuronidases descritas na literatura (MAGALHÃES; DA SILVA; ULHOA, 2008).

A massa molar relativa de $64,5 \mathrm{kDa}$ estimada para a hialuronidase de Crotalus durissus terrificus encontra-se na mesma faixa de massa molar descrita para a hialuronidase da arraia de água doce Potamotrygon motoro (MAGALHÃES; DA SILVA; ULHOA, 2008) e da peçonha de Heterometrus fulvipes (RAMANAIAH; PARTHASARATHY; VENKAIAK, 1990). Similarmente, Castanheira et al. (2008) determinaram que a hialuronidase de Crotalus durissus collilineatus possui aproximadamente $70 \mathrm{kDa}$. Harrison et al. (2007) analisaram hialuronidases obtidas de transcriptomas de glândulas de peçonha de víboras e determinaram massas molares variando de 50 a $70 \mathrm{kDa}$, cujos resultados são consistentes com 
publicações de hialuronidases de peçonhas viperídicas e elapídicas (CEVALLOS et al., 1992; GIRISH et al., 2002; KUDO; TU, 2001). As hialuronidases de Naja naja (GIRISH et al., 2004) e Agkistrodon contortrix contortrix (KUDO; TU, 2001) apresentam massa molar de 69.000 e 61.000, respectivamente. Esperava-se, portanto, que a enzima de Crotalus durissus terrificus também apresentasse alta massa molar, por ser da família Viperidae.

Cevallos et al. (1992) observaram que todas as hialuronidases das peçonhas dos invertebrados analisados (vespão Dolichovespula maculata, vespa Vespula germanica, formiga Pogonomyrmex rugosus e escorpião Centruroides limpidus limpidus) apresentaram massa molar menor que 50.000 e mostraram somente um componente, enquanto aquelas das peçonhas dos vertebrados (hialuronidase testicular bovina, de lagartos Heloderma horridum horridum e $H$. suspectum suspectum e de serpentes Lachesis muta, Crotalus basiliscus, Bothrops asper e Micrurus nigrocinctus) tinham uma massa molar maior que $60.000 \mathrm{e}$, em muitos casos, continham mais que uma isoforma ativa. Entretanto, hialuronidases com massa molar maior que 50.000 já foram purificadas de invertebrados e abaixo de $60 \mathrm{kDa}$ foram identificadas em vertebrados. A hialuronidase purificada da arraia de água doce Potamotrygon motoro migrou como uma banda única e a massa molar do monômero de 79 kDa foi estimada no gel de eletroforese de poliacrilamida (MAGALHÃES; DA SILVA; ULHOA, 2008). O escorpião Heterometrus fulvipes (RAMANAIAH; PARTHASARATHY; VENKAIAK, 1990), que é invertebrado, apresenta hialuronidase monomérica de 82 kDa. Enzimas com 14, 33, 51 e 116 kDa foram descritas, respectivamente, para as serpentes Vipera russelli (PUKRITTAYAKAMEE et al., 1988), e Agkistrodon acutus (XU et al., 1982), o escorpião Tityus serrulatus (PESSINI et al., 2001) e para Streptococcus agalactiae (OZEGOWSKI et al., 1994), confirmando que a maioria das hialuronidases descritas na literatura aparecem como um monômero e suas massas molares variam consideravelmente entre os organismos (MAGALHÃES; DA SILVA; ULHOA, 2008).

Hurtado et al. (2007) obtiveram para a hialuronidase da surucucu peruana Lachesis muta um rendimento de 38,6\%, em termos de atividade, e uma recuperação proteica de $0,8 \%$, com massa molar estimada por SDS-PAGE de $65 \mathrm{kDa}$ sob condições redutoras, $\mathrm{pH}$ ótimo 5,0 e a atividade específica da peçonha foi de 0,87 UTR/mg. Entretanto, Cevallos et al. (1992) estimaram a massa molar de 
115 kDa para a hialuronidase da mesma serpente em SDS-PAGE sem a utilização de agente redutor ou fervura, o que sugere que a hialuronidase presente na peçonha de Lachesis muta é dimérica.

Lokeshwar et al. (2002) demonstraram que a atividade hialuronidásica é regulada por splicing alternativo de $\mathrm{RNA}_{m}$. O splicing alternativo de $\mathrm{RNA}_{\mathrm{m}}$ controlou a expressão celular de hialuronidase enzimaticamente ativa, o que pode explicar os níveis elevados de hialuronidase nos cânceres de próstata e bexiga. Foram identificadas e caracterizadas diversas variantes splice dos genes HYAL1 e HYAL3 (LOKESHWAR et al., 2002). Cevallos et al. (1992) detectaram por zimografia atividade hialuronidásica para proteínas ofídicas com massa molar menor que 50.000. Harrison et al. (2007) identificaram através do cDNA da hialuronidase de Echis ocellatus "amplicons" pequenos, sem resíduos catalíticos de hialuronidase, com deleções centrais, codificando peptídeos truncados sem atividade hialuronidásica ou transcriptos não traduzidos. Segundo Harrison et al. (2007), os cDNAs codificadores de proteínas semelhantes a hialuronidase truncada identificados pelo grupo podem ser responsáveis pela atividade hialuronidásica detectada em zimogramas para proteínas de peçonhas de serpentes com massa molar em torno de 50.000 .

\subsubsection{Cromatografia de fase reversa}

A hialuronidase pura denominada "CdtHya1" obtida da HiTrap PhenylSepharose (Fig. 10) foi concentrada e recromatografada em coluna de fase reversa C4 (Fig. 13), como descrito no item 3.2.1.4.

A purificação em fase reversa em coluna C4 baseia-se no fracionamento de proteínas de hidrofobicidades diferentes. Essa etapa foi necessária para a determinação da sequência primária da porção amino-terminal da enzima e da massa molar por espectrometria de massas e comprovou a pureza da hialuronidase "CdtHya1" obtida da Phenyl-Sepharose (Fig. 13). 


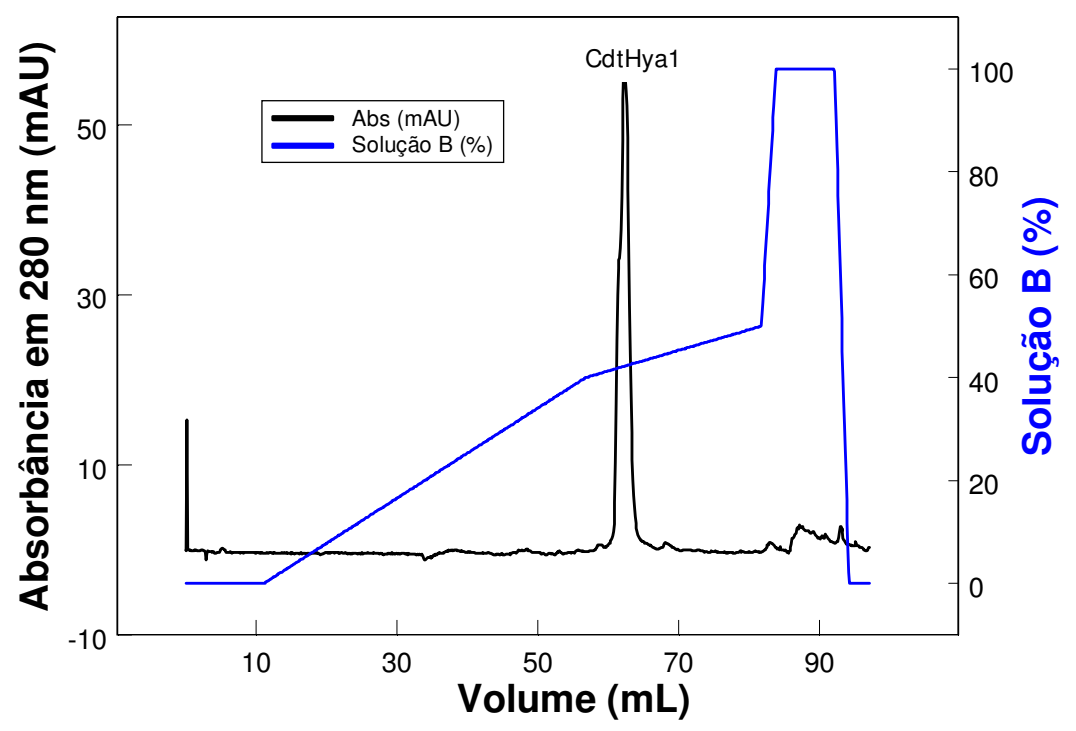

Figura 13. Perfil cromatográfico da "CdtHya1" em coluna de fase reversa $\mathrm{C} 4$. $\mathrm{O}$ fracionamento foi realizado em sistema FPLC Äkta Purifier UPC-10 com coluna C4 $(0,46 \times 25 \mathrm{~cm}$, com partículas de $5 \mu \mathrm{m}$, Shodex), equilibrada com a Solução A (TFA $0,1 \%$ ), sob vazão de $0,8 \mathrm{~mL} / \mathrm{min}$ e temperatura de $25^{\circ} \mathrm{C}$. A amostra $(2 \mathrm{~mL})$ foi inicialmente eluída com Solução $A$, seguindo-se um gradiente de concentração de acetonitrila (Solução B - Acetonitrila 60\% em TFA 0,1\%), representado pela linha azul. Volume coletado por tubo: $1,0 \mathrm{~mL}$.

Diversos ensaios foram realizados na tentativa de determinar experimentalmente o $\mathrm{pl}$ da hialuronidase de CdtV, como descrito no item 3.2.4. Contudo, o fato de a hialuronidase ser uma proteína de elevada massa molar, provavelmente dificulta a penetração da enzima na malha do gel de focalização isoelétrica, complicando a determinação do pl. Entretanto, como a enzima apresentou afinidade em pH 5,5 pela resina CMC-52 (Fig. 7), que é uma resina de troca catiônica, pode-se propor que a mesma apresente pl superior a 5,5. Caso contrário, a proteína teria carga-líquida negativa e não interagiria com a resina nesse $\mathrm{pH}$. Além disso, diversas hialuronidases descritas na literatura apresentam pls básicos: pl de 9,2 de Naja naja (GIRISH et al., 2004), pl de 8,75 de Streptococcus agalactiae (OZEGOWSKI et al., 1994) e pl de 9,2 do peixe-pedra Synanceja horrida (POH et al., 1992).

A recuperação e o rendimento das frações com atividade hialuronidásica obtidas no processo de purificação da enzima são apresentados na Tabela 1. 
Tabela 1. Recuperação e atividade específica dos componentes cromatografados no processo de purificação da hialuronidase de Crotalus durissus terrificus.

\begin{tabular}{l|cccccc}
\hline Fração & $\begin{array}{c}\text { Proteína } \\
\text { total * } \\
\text { (mg) }\end{array}$ & $\begin{array}{c}\text { Recuperação } \\
\text { proteica } \\
(\%)\end{array}$ & $\begin{array}{c}\text { Atividade } \\
\text { total } \\
\text { (UTR) }^{* *}\end{array}$ & $\begin{array}{c}\text { Rendimento } \\
\text { (\%) }\end{array}$ & $\begin{array}{c}\text { Atividade } \\
\text { específica } \\
\text { (UTR/mg) }\end{array}$ & $\begin{array}{c}\text { Atividade } \\
\text { relativa }\end{array}$ \\
\hline CdtV & 556 & 100,00 & 80.697 & 100,0 & 145 & 1,0 \\
CM6 & 5,5 & 0,99 & 10.000 & 12,4 & 1.805 & 12,4 \\
S2 & 2,5 & 0,45 & 5.198 & 6,4 & 2.079 & 14,3 \\
CdtHya1 & 1,3 & 0,23 & 6.586 & 8,2 & 5.066 & 34,9 \\
\hline
\end{tabular}

*Proteína total quantificada pelo método da absorbância 280/205 nm (SCOPES, 1974).

**Uma unidade turbidimétrica reduzida (UTR) é a quantidade de enzima necessária para hidrolisar $50 \%(10 \mu \mathrm{g})$ de hialuronan após 15 minutos de incubação a $37^{\circ} \mathrm{C}$.

Como descrito no item 3.2.1.1., cerca de $1 \mathrm{~g}$ da peçonha bruta de Crotalus durissus terrificus foi disperso em $50,0 \mathrm{~mL}$ de tampão no primeiro passo cromatográfico, ocorrendo precipitação de aproximadamente metade da massa pesada dispersa no tampão (Tabela 1). As proteínas totais presentes no sobrenadante foram quantificadas pelo método da absorbância 280/205 nm (SCOPES, 1974) e, posteriormente, o precipitado foi liofilizado e pesado.

A atividade específica para a peçonha solúvel foi 145 UTR/mg (unidades turbidimétricas reduzidas/mg) contra 5.066 UTR/mg para a hialuronidase CdtHya1, representando uma purificação de 34,9 vezes.

Hialuronidase tem sido considerada um componente presente em todas as peçonhas de serpentes (IWANAGA; SUZUKI, 1979a). Entretanto, há uma grande variação na atividade específica entre espécies de famílias diferentes e até mesmo dentre indivíduos de uma mesma espécie encontrados em regiões diferentes. A maioria das peçonhas elapídicas apresenta baixa atividade hialuronidásica, quando comparadas àquelas de víboras (PUKRITTAYAKAMEE et al., 1988; KUDO; TU, 2001).

A atividade hialuronidásica específica de 13 espécies de serpentes do sudeste asiático (PUKRITTAYAKAMEE et al., 1988), 19 espécies de serpentes encontradas em diferentes regiões da Ásia, Europa e América Central (KUDO; TU, 2001), 7 espécies de serpentes botrópicas e crotálicas brasileiras (BOLDRINI- 
FRANÇA et al., 2007) e a Lachesis muta peruana (HURTADO et al., 2007) é comparada na Tabela 2.

Observa-se nesta Tabela que, em geral, as peçonhas da família Viperidae apresentaram uma atividade hialuronidásica maior que as peçonhas da família Elapidae, com exceção da peçonha elapídica de Bungarus candidus (PUKRITTAYAKAMEE et al., 1988), que foi mais ativa do que as peçonhas da subfamília Viperinae e algumas espécies representantes da subfamília Crotalinae. Boldrini-França et al. (2007) relataram elevada atividade hialuronidásica na peçonha de Crotalus durissus collilineatus.

Kudo e Tu (2001), quando realizaram uma triagem da atividade hialuronidásica em 19 peçonhas de serpentes das famílias Elapidae e Viperidae (subfamílias Viperinae e Crotalinae) (Tabela 2), verificaram que esta atividade varia bastante entre as peçonhas de serpentes pertencentes ao mesmo gênero. Observou-se também variação na atividade específica de peçonhas da mesma espécie encontrada em regiões diferentes, como observado para a Bungarus fasciatus e Ophiophagus hannah, nas quais Pukrittayakamee et al. (1988) não encontraram evidência de atividade hialuronidásica, enquanto Kudo e Tu (2001) detectaram atividade, embora baixa, nestas mesmas espécies (Tabela 2).

Serpentes da mesma espécie podem secretar peçonhas com composições diferentes. A coloração amarela nas peçonhas ofídicas geralmente indica a presença da enzima L-aminoácido oxidase ( $\mathrm{Tu}^{11}$ apud DOS SANTOS et al., 1993). As serpentes Crotalus durissus ruruima secretam peçonhas que podem ser de cor amarela ou branca, apresentando atividades hemorrágica, necrótica e proteolítica distintas (DOS SANTOS et al., 1993).

\footnotetext{
${ }^{11}$ TU, A. T. Chemistry of rattlesnake venoms. In: TU, A. T. (Ed.). Rattlesnake Venoms Their Actions and Treatment. New York: Marcel Dekker. 1982, p. 247-312.
} 
Tabela 2. Atividade hialuronidásica da peçonha de diversas serpentes.

\begin{tabular}{|c|c|c|}
\hline Família & Gênero e espécie & $\begin{array}{l}\text { Ativ. Específica* } \\
\text { (UTR/mg) }\end{array}$ \\
\hline \multicolumn{3}{|l|}{ Elapidae } \\
\hline & Bungarus candidus** & 199,00 \\
\hline & Bungarus fasciatus ${ }^{* *}$ & 0,00 \\
\hline & Bungarus fasciatus ${ }^{* *}$ & 4,30 \\
\hline & Naja kaouthia** & 4,20 \\
\hline & Naja naja*** & 3,30 \\
\hline & Naja naja atra*** & 89,10 \\
\hline & Naja naja sputatrix ${ }^{* *}$ & 8,40 \\
\hline & Ophiophagus hannah** & 0,00 \\
\hline & Ophiophagus hannah*** & 18,80 \\
\hline \multicolumn{3}{|c|}{ Viperidae } \\
\hline & Agkistrodon bilineatus $^{* * *}$ & 60,30 \\
\hline & Agkistrodon contortrix contortrix ${ }^{* * *}$ & 243,00 \\
\hline & Agkistrodon contortrix laticinctus $* * *$ & 118,40 \\
\hline & Agkistrodon halys blomhoffii*** & 72,00 \\
\hline & Agkistrodon piscivorus leucostoma*** & 207,30 \\
\hline & Agkistrodon piscivorus piscivorus ${ }^{* *}$ & 109,30 \\
\hline & Agkistrodon rhodostoma ${ }^{* * *}$ & 92,00 \\
\hline & Bitis gabonica*** & 170,80 \\
\hline & Bothropoides jararaca (antiga Bothrops jararaca) ${ }^{* * *}$ & 378,78 \\
\hline & $\begin{array}{l}\text { Bothropoides pauloensis (antiga Bothrops } \\
\text { pauloensis) }\end{array}$ & 185,87 \\
\hline & Bothrops atrox ${ }^{* * *}$ & 73,10 \\
\hline & Bothrops jararacussu $u^{\star * \star *}$ & 5,13 \\
\hline & Bothrops moojeni**** & 268,80 \\
\hline & Calloselasma rhodostoma** & 20,90 \\
\hline & Crotalus adamanteus $s^{* * *}$ & 67,20 \\
\hline & Crotalus atrox $x^{* * *}$ & 148,70 \\
\hline & Crotalus basiliscus ${ }^{* * *}$ & 207,70 \\
\hline & Crotalus durissus collilineatus ${ }^{* * *}$ & 666,67 \\
\hline & Crotalus durissus terrificus ${ }^{\star \star * \star}$ & 196,85 \\
\hline & Crotalus horridus horridus ${ }^{* * *}$ & 156,80 \\
\hline & Lachesis muta\# & 0,87 \\
\hline & $\begin{array}{l}\text { Rinocerophis alternatus (antiga Bothrops } \\
\text { alternatus) }\end{array}$ & 189,75 \\
\hline & Trimeresurus albolabris ${ }^{* *}$ & 3,10 \\
\hline & Trimeresurus flavoviridis ${ }^{* *}$ & 41,60 \\
\hline & Trimeresurus macrops ${ }^{\star *}$ & 18,00 \\
\hline & Trimeresurus popeorum** & 3,00 \\
\hline & Vipera russelli ${ }^{\star \star \star}$ & 108,50 \\
\hline & Vipera russelli pulchella (Sri-Lanka) ${ }^{\star \star}$ & 19,60 \\
\hline & Vipera russelli russelli (Índia) ${ }^{* *}$ & 35,20 \\
\hline & Vipera russelli siamensis (Birmânia) ${ }^{* *}$ & 23,70 \\
\hline & Vipera russelli siamensis (Tailândia) ${ }^{\star \star}$ & 27,20 \\
\hline
\end{tabular}


Girish et al. (2004) purificaram a hialuronidase presente na peçonha da cobra Naja naja por gel filtração em coluna Sephadex-G75 e por troca catiônica em coluna CM-Sephadex C-25. Na primeira etapa, obtiveram recuperação de 34\% da atividade e $7 \%$ da proteína total aplicada para o pico ativo, enquanto na segunda etapa encontraram duas isoformas ativas, com recuperação de $5 \%$ da atividade e $0,15 \%$ da proteína aplicada para o quarto pico, e de 0,35\% e 0,013\%, respectivamente, para o quinto pico (GIRISH et al., 2004).

A recuperação proteica para a hialuronidase da peçonha bruta solúvel de Crotalus durissus terrificus foi de $0,23 \%$ e de $8,2 \%$ em termos de atividade (Tabela 1). Em estudos prévios foram utilizadas duas colunas de Heparin-Sepharose conectadas em série durante o terceiro passo cromatográfico (BORDON et al., 2012). No entanto, a recuperação proteica era cerca de dez vezes menor, comparado à Phenyl-Sepharose. Castanheira et al. (2008) recuperaram 0,21\% para a hialuronidase de Crotalus durissus collilineatus, enquanto Kudo e Tu (2001) obtiveram uma recuperação de $17 \%$ da atividade e $0,06 \%$ da proteína aplicada. Entretanto, Poh et al. (1992) recuperaram 57\% da atividade da hialuronidase do peixe-pedra Synanceja horrida e Pessini et al. (2001) recuperaram 43,6\% da atividade da hialuronidase que corresponde a $0,31 \%$ da peçonha solúvel do escorpião Tityus serrulatus.

O rendimento final de 2,90\% e a atividade de 4.000 UTR/mg foram obtidos para a hialuronidase de arraia de água doce Potamotrygon motoro (MAGALHÃES; DA SILVA; ULHOA, 2008). Resultados similares foram descritos por Xu et al. (1982), para a hialuronidase de serpente Agkistrodon acutus, o que demonstra a dificuldade associada à purificação desta enzima.

Esses resultados demonstram que a hialuronidase é pouco expressa em peçonhas. Embora a recuperação proteica da enzima proveniente de peçonhas de serpentes seja baixa, as hialuronidases de peçonhas são bastante ativas e potencializam a toxicidade das peçonhas (GIRISH et al., 2004; TU; HENDON, 1983). 


\subsection{Avaliação da atividade hialuronidásica por turbidimetria}

\subsubsection{Influência do pH}

A atividade hialuronidásica foi monitorada com relação à variação do $\mathrm{pH}$, conforme descrito no item 3.2.2.2. Nossos resultados indicaram que a hialuronidase apresentou maior atividade enzimática em tampão acetato de sódio 0,2 mol/L, na faixa de $\mathrm{pH}$ de 5,0 a 6,0, sendo máxima no pH 5,5 (Fig. 14). Portanto, esse tampão $\mathrm{pH} 5,5$ foi utilizado nos experimentos subsequentes.

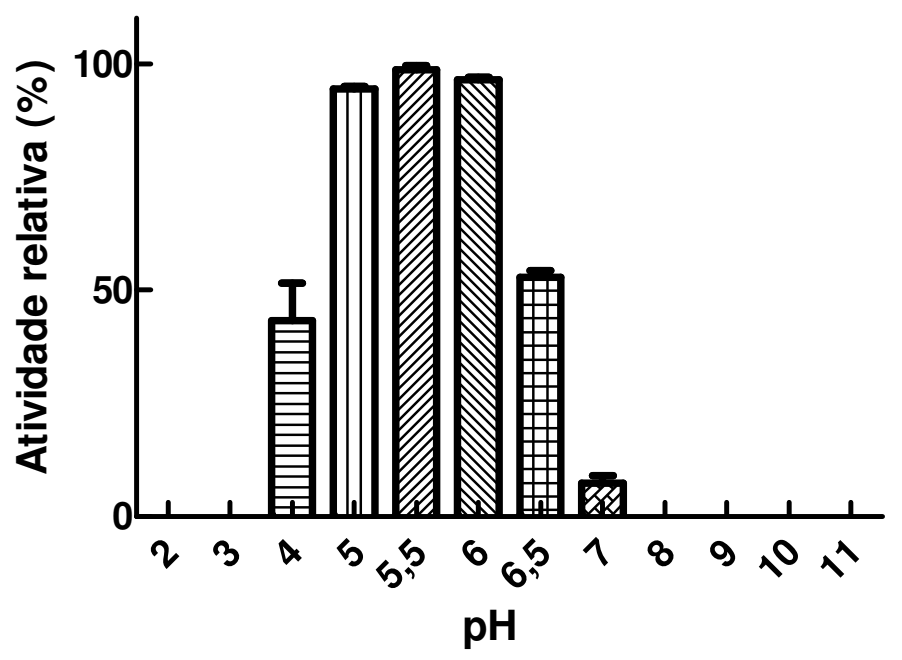

Figura 14. Perfil de atividade hialuronidásica em diferentes pHs para determinação do pH ótimo da hialuronidase da peçonha de Crotalus durissus terrificus. Foram adicionados $4 \mu \mathrm{L}$ de peçonha solúvel (1 $\mathrm{mg} / \mathrm{mL}$ em água) a diferentes tampões $0,2 \mathrm{~mol} / \mathrm{L}$, a vários $\mathrm{pHs}$, contendo $\mathrm{NaCl}$ 0,15 mol/L, e incubados com $20 \mu \mathrm{L}$ de hialuronan $(0,5 \mathrm{mg} / \mathrm{mL})$, por 15 minutos a $37{ }^{\circ} \mathrm{C}$. Os valores correspondem à média \pm EPM $(n=3)$.

A hialuronidase da peçonha de Crotalus durissus terrificus apresentou atividade máxima (100\%) em pH 5,5, sendo esse o seu pH ótimo, sofrendo perda de metade de sua atividade em $\mathrm{pH} 6,5$ e sendo praticamente inativa em $\mathrm{pH} 7,0$ (Fig. 14). Em contraste, a hialuronidase da peçonha de Tityus serrulatus apresentou cerca de $90 \%$ de atividade entre pHs 5,5 e 7,5 e cerca de $20 \%$ de atividade em pH 8,0 (PESSINI et al., 2001), o que mostra que a hialuronidase de Crotalus durissus terrificus é bastante instável sob variações de $\mathrm{pH}$.

A hialuronidase testicular bovina apresenta pH ótimo de 5,0 (KUDO; TU, 2001), sendo observada atividade máxima em pH 4,0 para a enzima de 
Heterometrus fulvipes (RAMANAIAH; PARTHASARATHY; VENKAIAK, 1990) e em pH 6,3 para a hialuronidase de Streptococcus agalactiae (OZEGOWSKI et al., 1994).

Como já relatado por alguns pesquisadores, peçonhas de serpentes, abelhas e escorpiões são ativas in vitro em uma faixa de $\mathrm{pH}$ de 4,0 a 6,0 (CEVALLOS et al., 1992; FISZER-SZAFARZ, 1984; IWANAGA; SUZUKI, 1979a, 1979b). Por exemplo, a enzima de Agkistrodon contortrix contortrix apresentou atividade máxima em $\mathrm{pH}$ 6,0 (KUDO; TU, 2001) e a hialuronidase de Naja naja não apresentou atividade em pHs abaixo de 4,0 e acima de 8,0 e seu pH ótimo é 5,0 (GIRISH et al., 2004).

De acordo com Gregory et al. ${ }^{12}$ (apud GIRISH et al., 2004), as hialuronidases são geralmente classificadas como enzima ácido-ativa (ativa entre $\mathrm{pH} 3$ e 4) ou neutro-ativa (ativa entre $\mathrm{pH} 5$ e 6). Como a hialuronidase de Crotalus durissus terrificus é mais ativa em $\mathrm{pH} 5,5$, a enzima pertence à classe neutro-ativa.

A literatura relata a instabilidade de diversas hialuronidases em $\mathrm{pH}$ neutro ou ligeiramente alcalino, nos quais a maioria dos componentes de peçonhas e venenos são ativos. Contudo, considerando que nos acidentes ofídicos as picadas atingem, na maioria das vezes, a derme (METZ et al., 2006) e que o pH normal da pele humana é ligeiramente ácido ( $\mathrm{pH}$ entre 4,6 e 5,8) (LEONARDI; GASPAR; MAIACAMPOS, 2002; SCHMID-WENDTNER; KORTING, 2006), a hialuronidase presente na peçonha da cascavel permanece ativa, atuando como "fator de espalhamento" das toxinas no tecido da vítima.

Outro ponto que pode ser citado é o fato que no envenenamento por animais peçonhentos ocorre a liberação de mediadores inflamatórios. Diversos exsudatos inflamatórios apresentam pH menor que o fisiológico, geralmente entre 6,9 e 6,0 (GAUTAM; BENSON; SLUKA, 2010), e esse valor de pH ligeiramente ácido, favorece o espalhamento das toxinas pela ação da hialuronidase.

\subsubsection{Influência da temperatura}

A hialuronidase da peçonha de Crotalus durissus terrificus apresentou maior atividade enzimática a $37^{\circ} \mathrm{C}$ (Fig. 15), sendo escolhida a temperatura de $37^{\circ} \mathrm{C}$, que é a temperatura fisiológica, para os experimentos subsequentes.

\footnotetext{
12 GREGORY, F. I.; TONY, C.; STERN, R. The hyaluronidases: a chemical, biological and clinical overview. Trends Glycols Glycotechnology, v. 8, p. 419-434, 1996.
} 


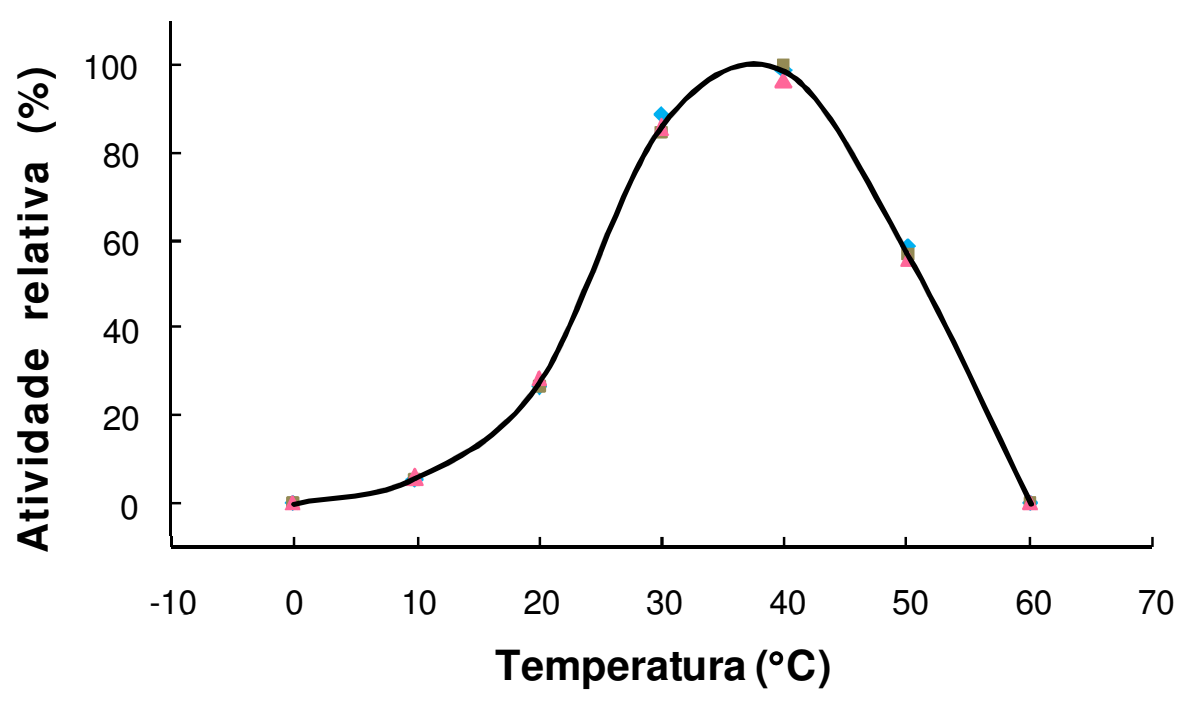

Figura 15. Perfil de atividade hialuronidásica em diferentes temperaturas para determinação da temperatura ótima da hialuronidase da peçonha de Crotalus durissus terrificus. Foram adicionados $4 \mu \mathrm{L}$ de peçonha solúvel ( $1 \mathrm{mg} / \mathrm{mL}$ em água) em tampão acetato de sódio $0,2 \mathrm{M}, \mathrm{pH} 5,5$, contendo $\mathrm{NaCl} 0,15 \mathrm{~mol} / \mathrm{L}$ e $20 \mu \mathrm{L}$ de hialuronan $(0,5 \mathrm{mg} / \mathrm{mL})$ e a mistura foi incubada por 15 minutos, a várias temperaturas. A curva corresponde aos valores das médias $(n=3)$.

A hialuronidase da peçonha de Crotalus durissus terrificus apresentou atividade máxima $(100 \%)$ a aproximadamente $37{ }^{\circ} \mathrm{C}$, sendo esta a temperatura ótima para sua atividade, e foi completamente desnaturada acima de $60{ }^{\circ} \mathrm{C}$ (Fig. 15). Similarmente, a hialuronidase de Streptococcus agalactiae apresentou atividade máxima a $40{ }^{\circ} \mathrm{C}$ (OZEGOWSKI et al., 1994) e as hialuronidases de Naja naja (GIRISH et al., 2004) e de Agkistrodon contortrix contortrix (KUDO; TU, 2001) apresentaram atividade máxima a $37^{\circ} \mathrm{C}$ e foram desnaturadas em temperaturas acima de $60{ }^{\circ} \mathrm{C}$.

As hialuronidases de diversas peçonhas de serpentes, como Naja haje, Dendroaspis viridis, Bitis gabonica e Vipera aspic, perdem sua conformação nativa pelo aquecimento a $60{ }^{\circ} \mathrm{C}$ (ELLIOTT, 1978). Em contraste, a hialuronidase de Tityus serrulatus é desnaturada em temperaturas acima de $80{ }^{\circ} \mathrm{C}$ e sua atividade é mais estável a variações de temperatura, apresentando atividade de aproximadamente $95 \%$ a $50{ }^{\circ} \mathrm{C}, 40 \%$ a $60{ }^{\circ} \mathrm{C}$ e $10 \%$ a $70{ }^{\circ} \mathrm{C}$ (PESSINI et al., 2001).

$\mathrm{A}$ atividade hialuronidásica de peçonhas apresenta considerável variação na estabilidade térmica. Algumas preparações perdem sua atividade rapidamente quando armazenadas acima de $4{ }^{\circ} \mathrm{C}$ (TU; HENDON, 1983), enquanto outras são 
estáveis e mantêm a atividade enzimática em temperatura ambiente por vários dias (ZANEVELD; POLAKOSKI; SCHUMACHER, 1973). A hialuronidase de Vipera russelli siamensis perde $15 \%$ da atividade depois de 2 semanas de armazenamento em solução, a $4{ }^{\circ} \mathrm{C}$ (PUKRITTAYAKAMEE et al., 1988), enquanto a enzima de Naja naja permaneceu estável por mais de 15 dias em tampão de ensaio de atividade hialuronidásica a $37^{\circ} \mathrm{C}$ (GIRISH et al., 2004).

Neste trabalho constatou-se que a hialuronidase de Crotalus durissus terrificus também é termolábil: uma alíquota da peçonha bruta recém-preparada e outra armazenada durante 60 dias a $-20{ }^{\circ} \mathrm{C}$ foram submetidas ao ensaio in vitro de determinação da atividade hialuronidásica por turbidimetria e observou-se uma redução de cerca de $60 \%$ na atividade do sobrenadante após o armazenamento, quando comparado com o sobrenadante da peçonha recém-preparada.

\subsubsection{Afinidade pelo substrato}

A fim de verificar a especificidade da hialuronidase de Crotalus durissus terrificus, a enzima e diferentes substratos foram incubados como descrito no item 3.2.2.2 e os resultados obtidos são apresentados na Figura 16.
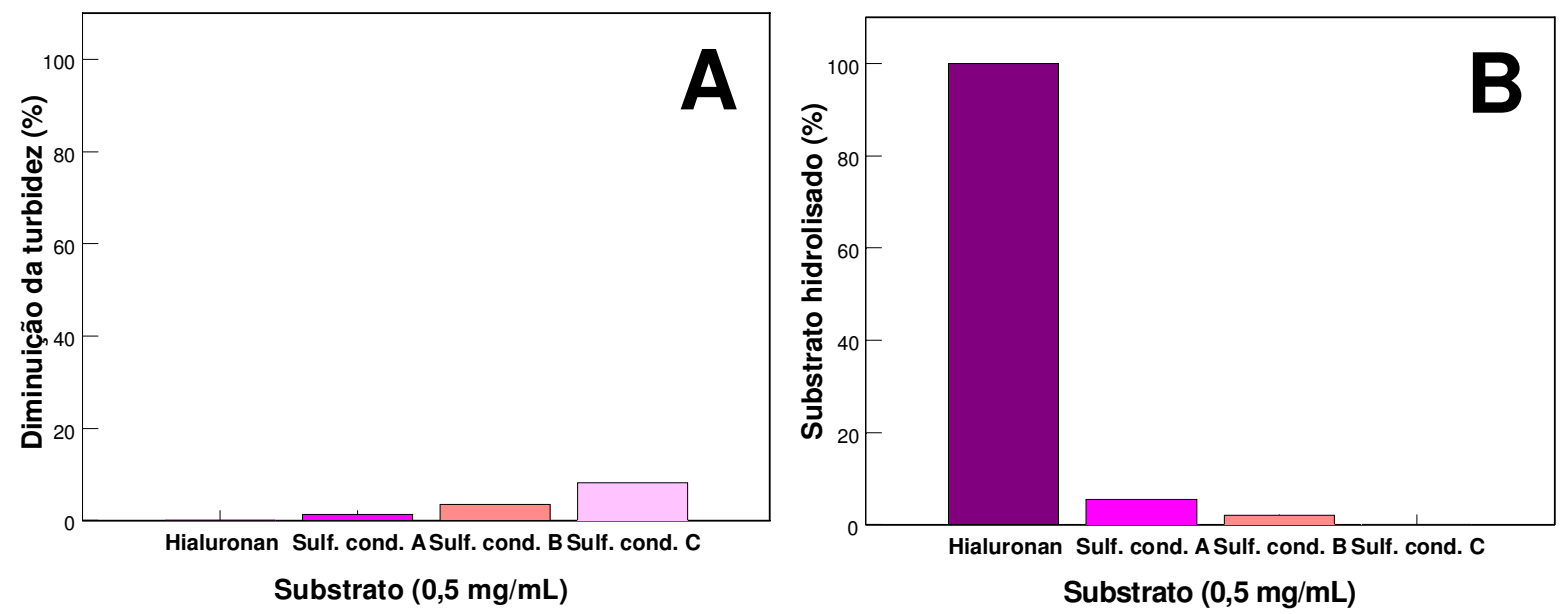

Figura 16. Atividade da hialuronidase pura de Crotalus durissus terrificus sobre diferentes substratos através da medida da diminuição de turbidez. A) Controle com adição de enzima inativa. B) Ensaio com a enzima ativa (valores já subtraídos dos correspondentes controles). A hialuronidase (3 UTR/9 $\mu \mathrm{L}$ em tampão acetato de sódio $0,05 \mathrm{~mol} / \mathrm{L}, \mathrm{pH} 5,5$ ) foi incubada por 15 minutos, a $37{ }^{\circ} \mathrm{C}$, com $20 \mu \mathrm{L}$ de substrato (hialuronan ou sulfatos de condroitina $\mathrm{A}$, B ou C) $0,5 \mathrm{mg} / \mathrm{mL}$ em tampão acetato de sódio 0,2 mol/L, $\mathrm{pH} 5,5$, contendo $\mathrm{NaCl}$ 0,2 mol/L. 
A hialuronidase apresentou maior atividade sobre o substrato hialuronan do que sobre os sulfatos de condroitina $A$ e $B$, sem hidrolisar o sulfato de condroitina $C$ nas condições do ensaio realizado (Fig. 16B). Embora esta hialuronidase tenha degradado parcialmente os sulfatos de condroitina A e B, observa-se sua elevada especificidade para hialuronan.

Observa-se na Figura 16A que, na presença da hialuronidase inativa, ocorre ligeira diminuição da turbidez da solução dos sulfatos de condroitina A, B e C. Desta forma, caso não tivesse sido realizado um controle com a enzima inativa, poderia ter-se chegado à conclusão equivocada de que o sulfato de condroitina $C$ fora hidrolisado pela hialuronidase. Portanto, essa figura revela a importância da utilização de controles ("brancos") adicionados de enzima inativa.

Hialuronidases da subclasse EC 3.2.1.35, que são encontradas em espermatozoides de mamíferos, lisossomas, venenos de himenópteros e peçonhas de serpentes, podem degradar hialuronan, sulfato de condroitina, principalmente o A, mas também o $C$, e, em menor extensão, o sulfato de condroitina B (STERN; CSÓKA, 2000).

Em contraste, a hialuronidase de Naja naja apresentou especificidade absoluta para hialuronan (GIRISH et al., 2004), assim como a hialuronidase purificada de Agkistrodon contortrix contortrix (KUDO; TU, 2001), enquanto a hialuronidase testicular bovina clivou diversas glicosaminoglicanas (GAGs) testadas, entre as quais hialuronan, condroitina, sulfatos de condroitina $A, C$ e D e quitosanas de alta, média e baixa massa molar (GIRISH et al., 2004).

\subsubsection{Efeito da concentração de sal}

Como o ensaio de atividade por turbidimetria é avaliado através da medida da diminuição de turbidez e envolve a presença de íons, os quais, por sua vez, alteram a solubilidade da amostra, foi realizado um controle negativo para eliminar possíveis interferências do $\mathrm{NaCl}$ utilizado na purificação da enzima por gradiente de concentração (Fig. 17A).

Para determinar a influência do cloreto de sódio na atividade da hialuronidase, utilizou-se várias concentrações de $\mathrm{NaCl}$ (0-1 mol/L) no tampão acetato de sódio $0,2 \mathrm{~mol} / \mathrm{L}, \mathrm{pH} 5,5$ (Fig. 17B). 


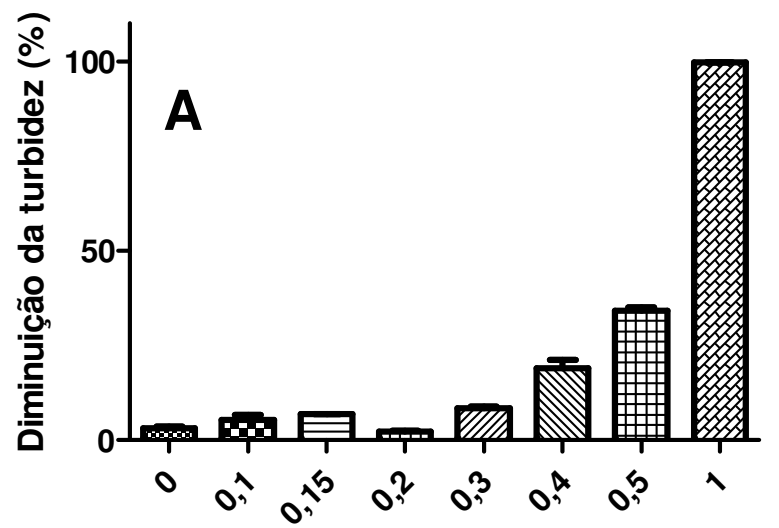

$[\mathrm{NaCl}](\mathrm{mol} / \mathrm{L})$

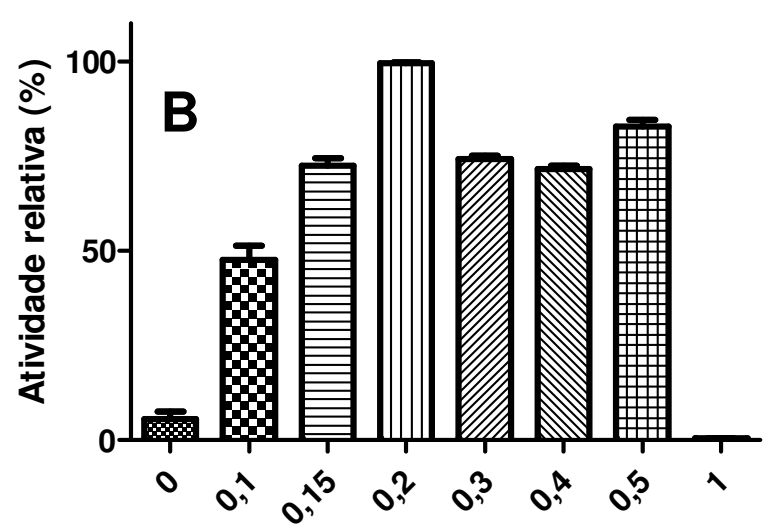

$[\mathrm{NaCl}](\mathrm{mol} / \mathrm{L})$

Figura 17. Efeito de diferentes concentrações de $\mathrm{NaCl}$ sobre a atividade da hialuronidase da peçonha de Crotalus durissus terrificus usando o método turbidimétrico. A) Controle negativo (sem adição de peçonha). B) Ensaio com a peçonha (valores subtraídos dos respectivos controles). A peçonha solúvel ( $4 \mu \mathrm{L}, 1 \mathrm{mg} / \mathrm{mL}$ em água) dispersa em tampão acetato de sódio $0,2 \mathrm{~mol} / \mathrm{L}, \mathrm{pH} 5,5$, contendo diferentes concentrações de $\mathrm{NaCl}(0-1 \mathrm{~mol} / \mathrm{L})$, foi incubada com $20 \mu \mathrm{L}$ de hialuronan $(0,5 \mathrm{mg} / \mathrm{mL})$, por 15 minutos, a $37^{\circ} \mathrm{C}$. Os valores correspondem à média $\pm \operatorname{EPM}(\mathrm{n}=3)$.

Até a concentração de $0,3 \mathrm{~mol} / \mathrm{L}$, não há grande interferência da concentração de $\mathrm{NaCl}$ presente no tampão de purificação para a determinação da atividade (Fig. 17A). Em concentrações acima de 0,3 mol/L, o cloreto de sódio reduz a turbidez da suspensão, fato que pode ser confundido com hidrólise, gerando um falso positivo, já que a atividade hialuronidásica é determinada pela redução da turbidez.

Altas concentrações de sal dificultam a complexação do BCTA com 0 hialuronan não hidrolisado, tornando a solução menos turva e dando a impressão de que o hialuronan foi clivado pela enzima. Pearce (1953) observou inibição do desenvolvimento da turbidez com concentrações de cloreto de sódio acima de $0,5 \mathrm{~mol} / \mathrm{L}$, quando a turbidez caiu para valores muito baixos. Portanto, com o objetivo de se evitar falso-positivos, devem ser utilizados controles negativos com o mesmo tampão utilizado na amostra-teste para se obter resultados fidedignos de atividade hialuronidásica, como apresentado na Figura 17A.

Após descontar os valores de redução de turbidez decorrentes do tampão utilizado na dispersão da amostra (Fig. 17A), a atividade enzimática máxima para a hialuronidase da peçonha de Crotalus durissus terrificus foi observada com tampão acetato de sódio 0,2 mol/L adicionado de $\mathrm{NaCl}$ 0,2 mol/L (Fig. 17B), sendo esta a 
concentração de cloreto de sódio utilizada nos ensaios turbidimétricos subsequentes. A hialuronidase de Agkistrodon contortrix contortrix também apresentou atividade máxima na presença de $\mathrm{NaCl}$ 0,2 mol/L (KUDO; TU, 2001). Já para a hialuronidase de Naja naja, a atividade foi máxima na presença de $\mathrm{NaCl}$ 0,15 mol/L e inibida em concentrações acima de 0,5 mol/L (GIRISH et al., 2004).

Analisando a Fig. 17B pode-se observar que a concentração de cloreto de sódio teve influência sobre a atividade hialuronidásica, uma vez que o aumento da concentração de $\mathrm{NaCl}$ levou a uma diminuição da atividade enzimática. Esse efeito foi observado principalmente na presença de $\mathrm{NaCl} 1 \mathrm{~mol} / \mathrm{L}$ e pode ser devido à neutralização de cargas entre o substrato e a enzima, impedindo a ligação entre o substrato e o sítio catalítico, como especulado para outras enzimas (MERHEB-DINI et al., 2009). Embora a atividade enzimática relativa tenha sido alta com tampão adicionado de $\mathrm{NaCl}$ 0,5 mol/L (Fig. 17B), esta condição não foi utilizada por gerar um falso positivo (Fig. 17A).

\subsubsection{Efeito da valência do sal}

Os sais podem afetar a eficiência catalítica por: (1) alterar o valor de $\mathrm{p} K_{a}$ dos resíduos de aminoácidos do sítio ativo (ABE et al., 1995); (2) enfraquecer as interações Coulômbicas entre o substrato e a enzima através do efeito contra-íon (PARK; RAINES, 2000; FISHER; SCHULTZ; RAINES, 1998); (3) inibir a atividade através da ligação de cátions metálicos diretamente à enzima (BOWERS; RAGLAND; BYERS, 2007); (4) aumentar a população de ligações de hidrogênio de ângulo elevado entre as moléculas de água da proteína, estabilizando uma conformação mais compacta e menos ativa da enzima (BEAUCHAMP; KHAJEHPOUR, 2010).

Para determinar a influência de cátions de valência diferente na atividade da hialuronidase, a enzima foi incubada em tampão acetato de sódio 0,2 mol/L, pH 5,5, contendo diferentes sais a 0,2 mol/L ( $\mathrm{NaCl}, \mathrm{KCl}, \mathrm{MgCl}_{2}$ e $\left.\mathrm{CaCl}_{2}\right)$ (Fig. 18). 


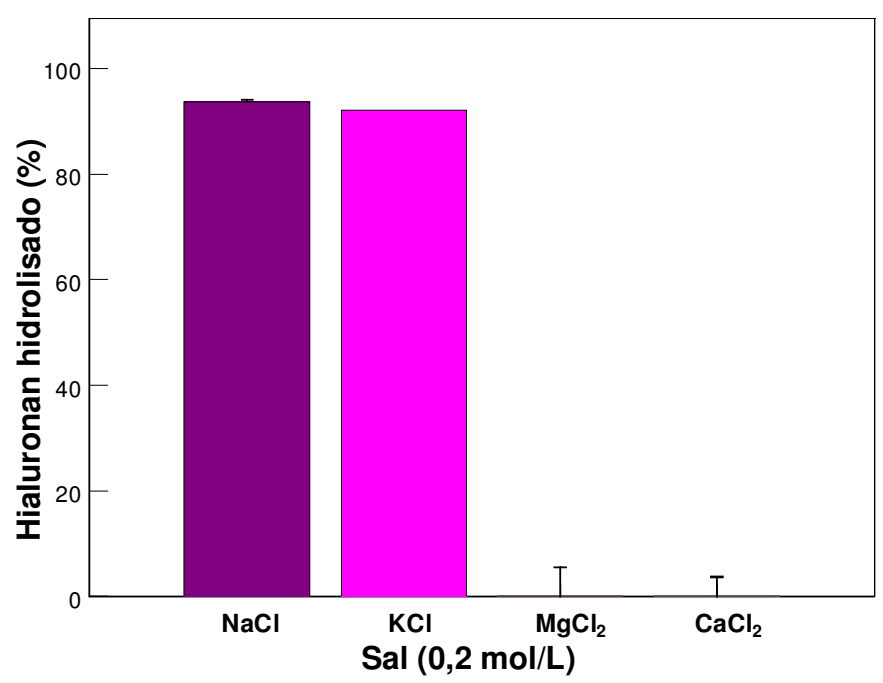

Figura 18. Atividade da hialuronidase pura de Crotalus durissus terrificus em tampão acetato de sódio 0,2 mol/L, pH 5,5 adicionado de diferentes cátions. A hialuronidase (1,6 UTR/6 $\mu \mathrm{L}$ em tampão acetato de sódio $0,05 \mathrm{~mol} / \mathrm{L}, \mathrm{pH} 5,5)$ foi incubada por 15 minutos, a $37{ }^{\circ} \mathrm{C}$, com $20 \mu \mathrm{L}$ de hialuronan $(0,5 \mathrm{mg} / \mathrm{mL})$ em tampão acetato de sódio $0,2 \mathrm{~mol} / \mathrm{L}, \mathrm{pH} 5,5$, contendo diferentes sais a $0,2 \mathrm{~mol} / \mathrm{L}\left(\mathrm{NaCl}, \mathrm{KCl}, \mathrm{MgCl}_{2}\right.$ e $\left.\mathrm{CaCl}_{2}\right)$. Os valores correspondem à média $\pm \mathrm{EPM}(\mathrm{n}=2)$.

A atividade da hialuronidase é máxima em tampão acetato de sódio $0,2 \mathrm{~mol} / \mathrm{L}$, pH 5,5, contendo cloreto de sódio ou potássio, como apresentado na Figura 18. Assim como observado para $\mathrm{NaCl} 0,2 \mathrm{~mol} / \mathrm{L}$ (Fig. 17A), o KCl 0,2 mol/L também não alterou a turbidez da solução no controle negativo (dados não apresentados). Portanto, a presença de íons monovalentes, como $\mathrm{Na}^{+}$e K $\mathrm{K}^{+}$, nesta concentração, é apropriada para a atividade hialuronidásica e não causa falso positivo no ensaio turbidimétrico.

Os íons magnésio e cálcio, que são cátions divalentes, na concentração de $0,2 \mathrm{~mol} / \mathrm{L}$ inibiram a clivagem do hialuronan pela hialuronidase (Fig. 18), causando a precipitação da amostra e aumento da turbidez. Em contraste, a atividade hialuronidásica de Agkistrodon contortrix contortrix não sofreu efeito de íons cálcio $0,2 \mathrm{~mol} / \mathrm{L}$ (KUDO; TU, 2001) e a hialuronidase de peixe-pedra não foi inibida por $\mathrm{MgCl}_{2} 5 \mathrm{mmol} / \mathrm{L}$ em tampão fosfato $0,05 \mathrm{~mol} / \mathrm{L}, \mathrm{pH} 5,5$ (POH et al., 1992).

Os cloretos de íons divalentes utilizados, $\mathrm{Ca}^{2+}$ e $\mathrm{Mg}^{2+}$, provocaram o aumento da turbidez da suspensão do controle negativo, que foi ainda mais evidente que aquela observada na suspensão contendo a enzima pura. Esses sais causaram precipitação do hialuronan, sendo esse fenômeno mais relevante com 
$\mathrm{CaCl}_{2}$ 0,2 mol/L. O cloreto de cálcio desidratou o hialuronan, acarretando na maior interação entre as moléculas do substrato, diminuição da solubilidade em meio aquoso e, consequentemente, precipitação da amostra e aumento da turbidez.

Ozegowski et al. (1994) observaram que a hialuronidase de Streptococcus agalactiae de duas cepas diferentes foi ativada por íons $\mathrm{Mg}^{2+}$ e inibida por íons $\mathrm{Zn}^{2+}$, $\mathrm{Al}^{3+}, \mathrm{Cu}^{2+}$ e $\mathrm{Fe}^{2+}$ na concentração final de $10 \mathrm{mmol} / \mathrm{L}$.

A literatura ainda não estabelece uma relação entre a estrutura da hialuronidase e a inibição ou ativação do sítio catalítico por alguns íons, pois ainda há lacunas no conhecimento sobre esta enzima. As hialuronidases desafiam os pesquisadores, pois são difíceis de purificar e, em muitas fontes, são encontradas em baixíssimas concentrações (STERN; CSÓKA, 2000). Para exemplificar as dificuldades encontradas na pesquisa com a enzima, a hialuronidase testicular humana, que é conhecida desde 1940 (CHAIN; DUTHIE, 1940), só foi caracterizada em 1993 (GMACHL et al., 1993).

\subsubsection{Ensaios de cinética enzimática}

Para os estudos cinéticos da hialuronidase, os experimentos foram realizados através de ensaio turbidimétrico que monitorou o consumo de substrato, como descrito no item 3.2.2.3.

A hialuronidase "CdtHya1" de CdtV seguiu a cinética de Michaelis-Menten catalisando reações que envolveram os substratos hialuronan e sulfatos de condroitina A, B e C.

A determinação de $K_{m}$ e $V_{\max }$ para cada substrato foi obtida através da derivação da curva elíptica de Michaelis-Menten pelo programa gráfico Prisma 6.0 (Fig. 19 e 20). 


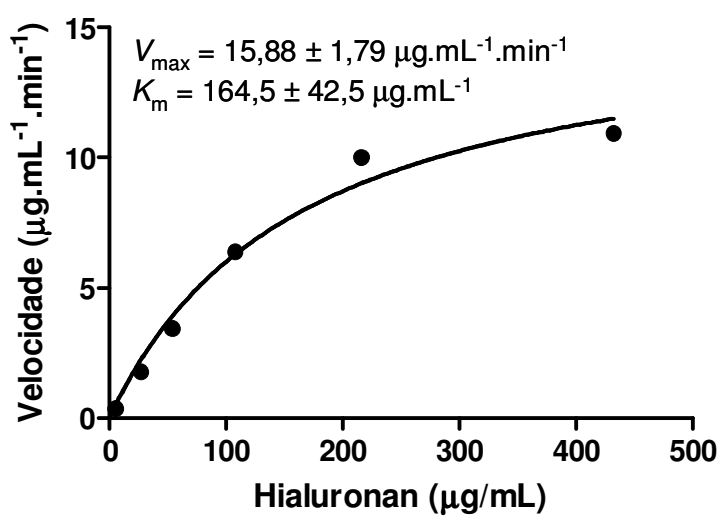

Figura 19. Curva cinética de Michaelis-Menten para hialuronan. Ensaio realizado com 2 UTR/6 $\mu \mathrm{L}$ de solução de hialuronidase $(0,07 \mu \mathrm{g} / \mu \mathrm{L}$ em tampão acetato de sódio $0,05 \mathrm{~mol} / \mathrm{L}$, pH 5,5$)$ em tampão acetato de sódio $0,2 \mathrm{~mol} / \mathrm{L}$ adicionado de cloreto de sódio $0,2 \mathrm{~mol} / \mathrm{L}, \mathrm{pH} 5,5$, contendo hialuronan $(5,4$ a $432 \mu \mathrm{g} / \mathrm{mL})$. São correlacionadas a velocidade $\left(\mu \mathrm{g} \cdot \mathrm{mL}^{-1} \cdot \mathrm{min}^{-1}\right)$ de hidrólise do substrato pela hialuronidase de CdtV versus a concentração de hialuronan $(\mu \mathrm{g} / \mathrm{mL})$ presente na mistura do ensaio.
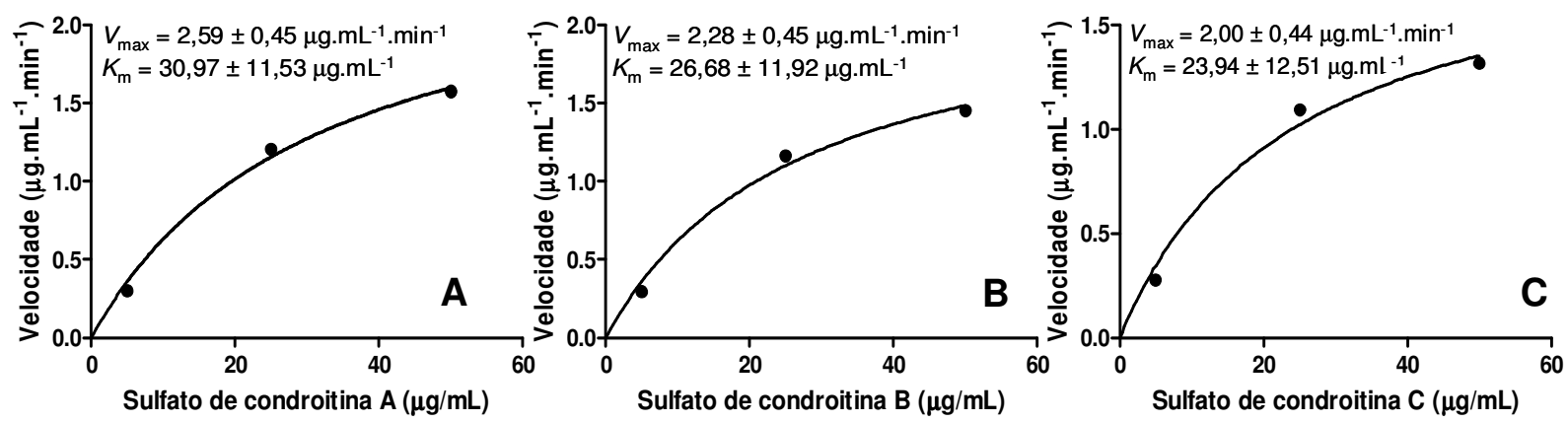

Figura 20. Curva cinética de Michaelis-Menten para sulfatos de condroitina. A) Sulfato de condroitina A. B) Sulfato de condroitina B. C) Sulfato de condroitina C. Ensaios realizados com $3 \mathrm{UTR} / 9 \mu \mathrm{L}$ de solução de hialuronidase $(0,07 \mu \mathrm{g} / \mu \mathrm{L}$ de tampão acetato de sódio $0,05 \mathrm{~mol} / \mathrm{L}, \mathrm{pH} 5,5)$, em uma solução contendo sulfato de condroitina A, B ou C (5 a $50 \mu \mathrm{g} / \mathrm{mL})$ em tampão acetato de sódio $0,2 \mathrm{~mol} / \mathrm{L}$ adicionado de cloreto de sódio $0,2 \mathrm{~mol} / \mathrm{L}, \mathrm{pH} 5,5$. São correlacionadas a velocidade ( $\mu \mathrm{g} \cdot \mathrm{mL}^{-1} \cdot \mathrm{min}^{-1}$ ) de hidrólise do substrato pela hialuronidase de CdtV versus a concentração de sulfato de condroitina A, B ou C $(\mu \mathrm{g} / \mathrm{mL})$ presente na mistura do ensaio.

O número de turnover $\left(K_{c a t}\right)$ e a eficiência catalítica $\left(K_{c a t} / K_{m}\right)$ da hialuronidase de Crotalus durissus terrificus para os substratos hialuronan e sulfatos de condroitina A, B e C, calculados a partir dos valores de $K_{m}$ e $V_{\max }$ determinados nas Figuras 19 e 20, são comparados na Tabela 3. 
Tabela 3. $K_{c a t}, K_{m}$ e $K_{c a t} / K_{m}$ da hialuronidase de Crotalus durissus terrificus para os substratos testados.

\begin{tabular}{l|cccc}
\hline \multicolumn{1}{c|}{ Parâmetros } & Hialuronan & $\begin{array}{c}\text { Sulfato de } \\
\text { condroitina A }\end{array}$ & $\begin{array}{c}\text { Sulfato de } \\
\text { condroitina } B\end{array}$ & $\begin{array}{c}\text { Sulfato de } \\
\text { condroitina } \boldsymbol{C}\end{array}$ \\
\hline$K_{\text {cat }}\left(\mathrm{min}^{-1}\right)^{*}$ & $3.781,0$ & 410,6 & 361,3 & 317,5 \\
$K_{m}\left(\mu \mathrm{g} \cdot \mathrm{mL}^{-1}\right)$ & 164,5 & 31,0 & 26,7 & 24,0 \\
$K_{\text {cat }} K_{m}\left(\mu \mathrm{g}^{-1} \cdot \mathrm{mL} \cdot \mathrm{min}^{-1}\right)^{* *}$ & 23,0 & 13,3 & 13,5 & 13,3 \\
\hline
\end{tabular}

${ }^{*} K_{c a t}=V_{\max } /[\mathrm{E}]$, sendo $[\mathrm{E}]$ a concentração da enzima no volume final do ensaio; $K_{\text {cat }}$ ou número de renovação (número de turnover) é o número de vezes que cada sítio catalítico converte o substrato em produto por unidade de tempo. ${ }^{* *} K_{c a t} / K_{\mathrm{m}}$, corresponde à eficiência catalítica, ou seja, é o número de moléculas de substrato convertidas em produto por sítio catalítico por unidade de tempo.

Durante os ensaios de cinética enzimática observou-se que o uso de substrato em excesso provavelmente forma agregados que dificultam o acesso da hialuronidase ao mesmo, provocando turbidez da suspensão maior que o esperado. Nos ensaios com os sulfatos de condroitina A, B e C, este comportamento foi ainda mais evidente, o que impossibitou o uso desses substratos em concentrações acima de $50 \mu \mathrm{g} / \mathrm{mL}$ (item 3.2.2.3).

Embora a CdtHya1 tenha apresentado maior afinidade (menor $K_{m}$ ) sobre o sulfato de condroitina $\mathrm{C}$, verifica-se a menor taxa de hidrólise sobre este substrato (Tabela 3). Especula-se que isso seja decorrente do grupo sulfato estar na posição 6 (Fig. $21 \mathrm{C}$ ), visto que nos outros substratos o grupo sulfato encontra-se na posição 4 do açúcar N-acetil-D-galactosamina (Fig. 21A-B). CdtHya1 apresenta praticamente a mesma eficiência catalítica sobre os sulfatos de condroitina A, B e C (Tabela 3), sendo ligeiramente maior sobre o sulfato de condroitina $B$, que possui o açúcar ácido D-idurônico (Fig. 21B) ao invés do ácido D-glicurônico encontrado nos demais.

Os substratos hialuronan e sulfato de condroitina (Fig. 21) são glicosaminoglicanas (GAGs) encontradas na matriz extracelular, com padrões de sulfatação e tamanho bastante distintos que interferem na força de ligação e especificidade de enzimas para estes substratos (PICHERT et al., 2012). Estudos experimentais e computacionais mostraram que o aumento no padrão de sulfatação de GAGs, em geral, melhora a ligação destas ao sítio-alvo e a posição do grupamento sulfato resulta em especificidade de ligação diferente (PICHERT et al., 2012). 


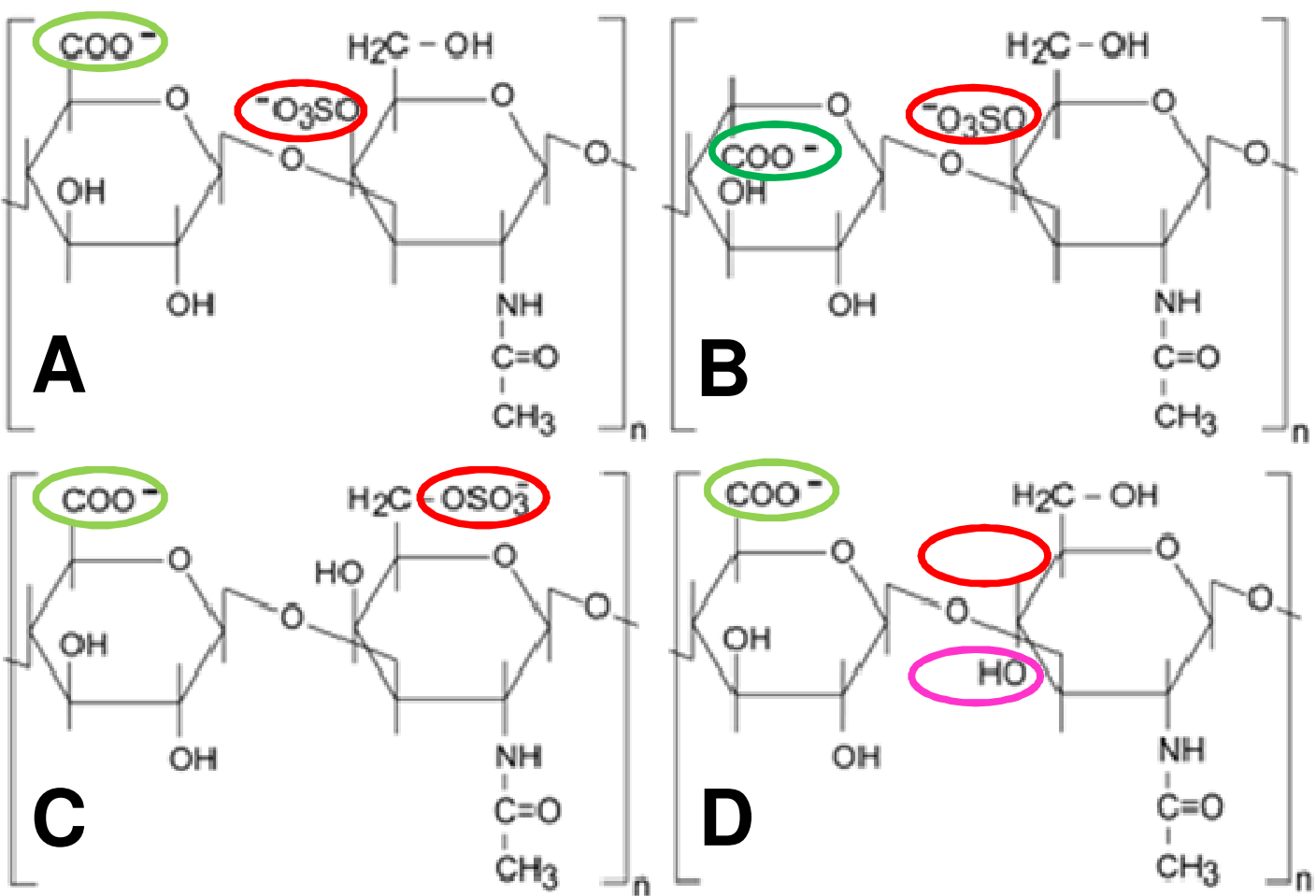

Figura 21. Estruturas de glicosaminoglicanas com algumas diferenças em destaque. A) Sulfato de condroitina A; B) Sulfato de condroitina B; C) Sulfato de condroitina C; D) Hialuronan. (PICHERT et al., 2012).

Observa-se na Tabela 3 que, embora a hialuronidase CdtHya1 tenha degradado parcialmente os sulfatos de condroitina $A, B$ e $C$, a enzima da peçonha de Crotalus durissus terrificus apresenta maior eficiência catalítica $\left(K_{c a t} K_{m}\right)$ sobre hialuronan. Esses resultados corroboram a observação feita pela análise da Figura 16B de que, embora a hialuronidase de Crotalus durissus terrificus tenha degradado parcialmente os sulfatos de condroitina $A$ e $B$, constatou-se sua elevada atividade sobre hialuronan. Interessantemente, CdtHya1 apresentou menor afinidade (maior $K_{m}$ ) e maior taxa de hidrólise $\left(K_{c a t}\right)$ sobre hialuronan, do que sobre as outras GAGs testadas. Acredita-se que este intrigante resultado seja decorrente das diferenças no tamanho e no padrão de sulfatação dos substratos avaliados. 0 hialuronan utilizado apresenta massa molar entre $3 \times 10^{6}$ e 5,8 $\times 10^{6}$, enquanto os sulfatos de condroitina apresentam de $1 \times 10^{4}$ a $4 \times 10^{4} \mathrm{Da}$ (informação técnica do fornecedor). Como o hialuronan é bem maior que os outros substratos, ele apresenta um número maior de unidades dissacarídeos e, portanto, um maior número de ligações $\beta-1,4$ a serem clivadas, assim facilitando o acesso de CdtHya1 ao sítio de 
hidrólise. Outra diferença é que o hialuronan é formado por N-acetil-D-glicosamina (Fig. 21D), enquanto as outras GAGs testadas são formadas por N-acetil-Dgalactosamina-sulfato (Fig. 21A-C). Hialuronan é uma GAG linear acídica nãosulfatada. Ou seja, não possui o grupamento sulfato, que parece ser importante para a ligação do substrato com a enzima, resultando no menor valor de $K_{m}$ de CdtHya1 sobre hialuronan. Já a presença de N-acetil-D-glicosamina parece ser responsável pela maior taxa de hidrólise de CdtHya1 sobre hialuronan. Portanto, sugere-se que a enzima CdtHya1 apresentaria a maior afinidade (menor $K_{m}$ ) e maior taxa de hidrólise $\left(K_{c a t}\right)$ sobre sulfato de hialuronan. Essa sugestão vai ao encontro dos resultados publicados de que hialuronan O-sulfatado foi o inibidor de hialuronidase mais forte entre todas as GAGs O-sulfatadas testadas (TOIDA et al., 1999; GIRISH et al., 2009).

Estudos relatam que hialuronidases de peçonhas ofídicas (EC 3.2.1.35) degradam hialuronan e sulfatos de condroitina $A, B$ e $C$, produzindo principalmente tetrassacarídeos (EL-SAFORY; FAZARY; LEE, 2010). Em contraste, hialuronidases das peçonhas de Naja naja (GIRISH et al., 2004) e Agkistrodon contortrix contortrix (KUDO; TU, 2001) apresentam especificidade absoluta para hialuronan.

A hialuronidase de Crotalus durissus terrificus apresentou sobre hialuronan $K_{m}$ de $164,5 \mu \mathrm{g} / \mathrm{mL}$ e $V_{\max }$ de $15,88 \mu \mathrm{g} \cdot \mathrm{mL}^{-1} \cdot \mathrm{min}^{-1}$, como demonstrado na Figura 19. $K_{m}$ é uma constante definida como a concentração para a qual a velocidade da reação enzimática é metade de $V_{\text {max }}$.

A hialuronidase da arraia de água doce Potamotrygon motoro, conhecida como arraia-de-fogo ou arraia motoro, tem $K_{\mathrm{m}}$ de $4,91 \mu \mathrm{g} / \mathrm{mL}$ (MAGALHÃES; DA SILVA; ULHOA, 2008), o que indica que esta enzima tem maior afinidade para hialuronan do que outras enzimas, pois esse valor foi substancialmente menor que aqueles publicados para os escorpiões Palamneus gravimanus $(47,61 \mu \mathrm{g} / \mathrm{mL})$ (MOREY et al., 2006) e Tityus serrulatus (69,7 $\mu \mathrm{g} / \mathrm{mL}$ ) (PESSINI et al., 2001), para Streptococcus agalactiae (81,7 $\mathrm{g} / \mathrm{mL}$ ) (OZEGOWSKI et al., 1994), testículo bovino (304 $\mu \mathrm{g} / \mathrm{mL})$ e peixe-pedra Synanceja horrida $(709 \mu \mathrm{g} / \mathrm{mL})(\mathrm{POH}$ et al., 1992). Vale ressaltar que embora a hialuronidase do peixe-pedra apresente a menor afinidade por hialuronan dentre as demais citadas, a atividade específica desta enzima é cerca 
de $10^{4}$ a $10^{6}$ vezes maior que aquela encontrada nas peçonhas de serpentes (POH et al., 1992).

Experimentalmente, o $K_{\mathrm{m}}$ de uma enzima, em geral, é semelhante à concentração celular do seu substrato. Ou seja, uma enzima cujo substrato é abundante no interior celular tem um elevado valor de $K_{m}$ (LEHNINGER, 1976). A melhor maneira para comparar a eficiência catalítica de diferentes enzimas ou o número de renovação de diferentes substratos para uma mesma enzima é através da relação $K_{\text {cat }} / K_{m}$ para as duas reações. O limite superior para esta relação é controlado pela difusão em uma solução aquosa e é da ordem de $10^{8}$ a $10^{9}$ mol.L ${ }^{-1} \cdot \mathrm{s}^{-1}$ (LEHNINGER, 1976).

Estimar os valores de $K_{m}$ e $V_{\max }$ nos gráficos não lineares era muito difícil. Para atingir esse objetivo, foram desenvolvidos métodos de linearização da equação de Michaelis-Menten, como gráfico de Lineweaver-Burk (LINEWEAVER; BURK, 1934), o diagrama de Eadie-Hofstee (ATKINS; NIMMO, 1975) e o gráfico de HanesWoolf (HANES, 1932). O gráfico de Lineweaver-Burk ou representação de duplo recíproco é a forma mais comum, e simples, de mostrar os dados cinéticos, apesar de não ser a mais confiável. Geralmente, as medidas realizadas a baixas concentrações de substrato são distorcidas nos gráficos de Lineweaver-Burk, resultando em estimativas não muito exatas de $V_{\max }$ e de $K_{m}$ (TSENG; HSU, 1990). Com a utilização de computadores e de softwares adequados, que permitem ajustar regressões não lineares de forma simples, a linearização foi substituída por métodos mais confiáveis baseados na análise de regressão não linear (GRECO; HAKALA, 1979). Por esse motivo, o programa gráfico Prisma 6.0 foi utilizado para fazer a derivação da curva elíptica de Michaelis-Menten (Fig. 19 e 20).

\subsection{Identificação de glicoproteínas em gel desnaturante de poliacrilamida}

Para verificar a presença de glicoproteínas na peçonha de Crotalus durissus terrificus, foi realizada SDS-PAGE em condições não redutoras com as frações com atividade hialuronidásica eluídas de cada passo cromatográfico (Fig. 22), como descrito no item 3.2.5. 


\section{$\begin{array}{lllll}1 & 2 & 3 & 4 & 5\end{array}$}

Figura 22. Perfil eletroforético das frações com atividade hialuronidásica em gel desnaturante de poliacrilamida a $10 \%$ corado com reagente de Schiff para detecção de glicoproteínas. Poço 1: CM6; 2: Padrão de massa molar (GE cód. 17-0615-01): Miosina 212 kDa, a $a_{2}$-macroglobina $170 \mathrm{kDa}, \beta$-galactosidase $116 \mathrm{kDa}$, Transferrina $76 \mathrm{kDa}$, Subunidade da $\alpha_{2}$-macroglobina $70 \mathrm{kDa}$, Glutamato desidrogenase 53 kDa; 3: S2; 4: CdtHya1; 5: Padrão de massa molar (Sigma cód. M3913): Soralbumina bovina $66 \mathrm{kDa}$, Ovalbumina $45 \mathrm{kDa}$, Gliceraldeído-3-fosfato desidrogenase $36 \mathrm{kDa}$, Anidrase Carbônica 29 kDa, Tripsinogênio 24 kDa.

Nos poços 3 e 4, apresentados na Figura 22, foi revelada apenas uma banda de glicoproteína, que corresponde à hialuronidase, visto que a hialuronidase pura "CdtHya1" foi aplicada no poço 4, sugerindo assim que a hialuronidase de Crotalus durissus terrificus é uma glicoproteína. No poço 1, correspondente à fração "CM6", observam-se também glicoproteínas de baixa massa molar, além da banda correspondente à hialuronidase.

Polissacarídeos, glicosaminoglicanas (GAGs) ou glicolipídeos, após degradação ácida, são corados pelo reagente de Schiff. O ácido periódico, utilizado no protocolo para corar, oxida o grupo funcional diol presente nos açúcares, gerando aldeídos que reagem com o reagente de Schiff e resultam na coloração magenta (DEEPAK et al., 2003).

O conteúdo de carboidrato de hialuronidases descritas na literatura varia de 7 a 20\%: 7,17\% da testicular humana (BORDERS; RAFTERY, 1968); 7,24\% da nativa de Apis mellifera (KEMENY et al., 1984); 7,25\% do bacteriófago estreptocócico tipo 49 do grupo A (BENCHETRIT et al., 1978); 17\% de Staphylococcus aureus (RAUTELA; ABRAMSON, 1973); 18,44\% de Lachesis muta 
(HURTADO et al., 2007) e $20 \%$ da PH-20 do esperma de Macaca sp. (LI et al., 2002).

Os carboidratos são importantes para a conformação da estrutura da hialuronidase e sabe-se que, para outras enzimas, os carboidratos desempenham um papel fundamental nos fenômenos de reconhecimento antigênico.

Para estudar o papel de resíduos de carboidratos na interação da hialuronidase da peçonha de abelha com Imunoglobulina E ( $\lg E)$, Soldatova et al. (2002) produziram mutantes para o sítio de glicosilação desse alérgeno. A ausência da porção carboidrato na cadeia polipeptídica da hialuronidase recombinante de abelha não alterou sua ligação com anticorpos; contudo estas mutações causaram agregação proteica decorrente da desestabilização parcial da molécula.

A hialuronidase de vespa foi submetida à clivagem dos glicopeptídeos pela enzima $\mathrm{N}$-glicosidase e posterior análise por espectrometria de massas, revelando três peptídeos correspondentes à N-glicosilação na Asn79 e 127. A clivagem com a enzima $\mathrm{N}$-glicosidase $\mathrm{A}$ revelou dois peptídeos que correspondem à $\mathrm{N}$-glicosilação na Asn99. Os espectros de massa demonstraram também que Asn79 e 99 podem ser expressos sem N-glicanas. Em decorrência dessa heterogeneidade nos padrões de N-glicosilação, a diagnose in vitro de indivíduos alérgicos à peçonha de vespa é bastante complexa (SEPPÄLÄ et al., 2006). Variações no padrão de glicosilação são responsáveis pela diversidade de funções biológicas entre as isoformas das proteínas (APWEILER; HERMJAKOB; SHARON, 1999; GAGNEUX; VARKI, 1999).

Uma vez que a glicosilação protege glicoproteínas da desnaturação térmica (Schauer; Kamerling ${ }^{13}$ apud FISZER-SZAFARZ; LITYNSKA; ZOU, 2000), a atividade das hialuronidases sérica e placentária foi avaliada após tratamento com sialidase e aquecimento a $45{ }^{\circ} \mathrm{C}$. Observou-se que a enzima sérica manteve $80 \%$ de sua atividade, enquanto a hialuronidase placentária manteve apenas $10 \%$ da atividade inicial, sugerindo que a hialuronidase sérica possui maior conteúdo total de açúcar e de ácido siálico do que a enzima placentária (FISZER-SZAFARZ; LITYNSKA; ZOU, 2000).

\footnotetext{
${ }^{13}$ SCHAUER, R.; KAMERLING, J. P. Chemistry, biochemistry and biology of sialic acids. In: MONTREUIL, J.; VLIEGENTHART, J. F. G.; SCHACHTER, H. (Ed.). Glycoproteins II, Amsterdam: Elsevier, p. 243-402, 1997.
} 
A remoção de $\mathrm{N}$-glicanas da hialuronidase $\mathrm{PH}-20$ do esperma de macaco com N-glicosidase $\mathrm{F}$ deslocou a massa molar de $64 \mathrm{kDa}$ para $54 \mathrm{kDa}$, a mesma massa molar deduzida com base em análise sequencial. Sugeriu-se que manose é um açúcar importante no interior ou na extremidade terminal da glicana ligada, enquanto o ácido siálico e fucose não são açúcares terminais da superfície da $\mathrm{PH}-20$ do esperma. A deglicosilação da superfície da $\mathrm{PH}-20$ do esperma resultou na perda completa da sua atividade hialuronidásica. Portanto, a atividade da $\mathrm{PH}-20$ é dependente das características estruturais estabelecidas por glicosilação (LI et al., 2002).

Foram realizados alguns ensaios em colaboração com a Profa. Dra. Carem Gledes Vargas Rechia para determinar o conteúdo de carboidratos na hialuronidase de Crotalus durissus terrificus. Foi utilizado o método do fenol sulfúrico (DUBOIS et al., 1956) e obteve-se o teor de 2,9\% (dados não apresentados). Contudo, esses experimentos devem ser repetidos para confirmar a porcentagem de carboidratos da enzima.

Até o momento, não há relatos na literatura de hialuronidases O-glicosiladas. Não houve evidências de O-glicosilação para PH-20 de Macaca sp. (LI et al., 2002) nem para o alérgeno de Apis mellifera (KUBELKA; ALTMANN; MARZ, 1995).

\subsection{Atividade edematogênica}

Avaliou-se o papel da hialuronidase como "fator de espalhamento" de crotoxina e fosfolipase $A_{2}$. A crotoxina é o principal componente neurotóxico isolado de CdtV e consiste de um complexo proteico reversível composto por uma PLA 2 básica e por crotapotina (RUBSAMEN; BREITHAUPT; HABERMANN, 1971). Crotapotina, a subunidade não-tóxica, age como uma chaperona, aumentando as atividades biológicas da PLA 2 (HABERMANN; BREITHAUPT, 1978). PLA $A_{2}$ induz a liberação de mediadores inflamatórios, vasodilatores e vasoconstritores, gerando diversos efeitos tóxicos que mimetizam o envenenamento com a peçonha total (GIRISH; KEMPARAJU, 2011). PLA 25 isoladas de peçonhas podem induzir ou exacerbar a resposta inflamatória (TEIXEIRA et al., 2003), produzindo edema de pata em roedores utilizados como modelos (TOYAMA et al., 2009). A formação de 
edema observada após acidentes ofídicos ocorre devido ao aumento da permeabilidade vascular (GUTIERREZ; RUCAVADO, 2000; GIRISH; KEMPARAJU, 2007) ou à geração/liberação de diversos mediadores inflamatórios (CAMARA et al., 2003; CHAVES et al., 1998; GIRISH; KEMPARAJU, 2011; TEIXEIRA et al., 2005).

O edema de pata causado pelas toxinas fosfolipase $A_{2}\left(P L A_{2}\right)$ e crotoxina na presença e ausência de hialuronidase, pelo controle (tampão acetato) e pela hialuronidase, como descrito no item 3.2.6, está representado na Figura 23.

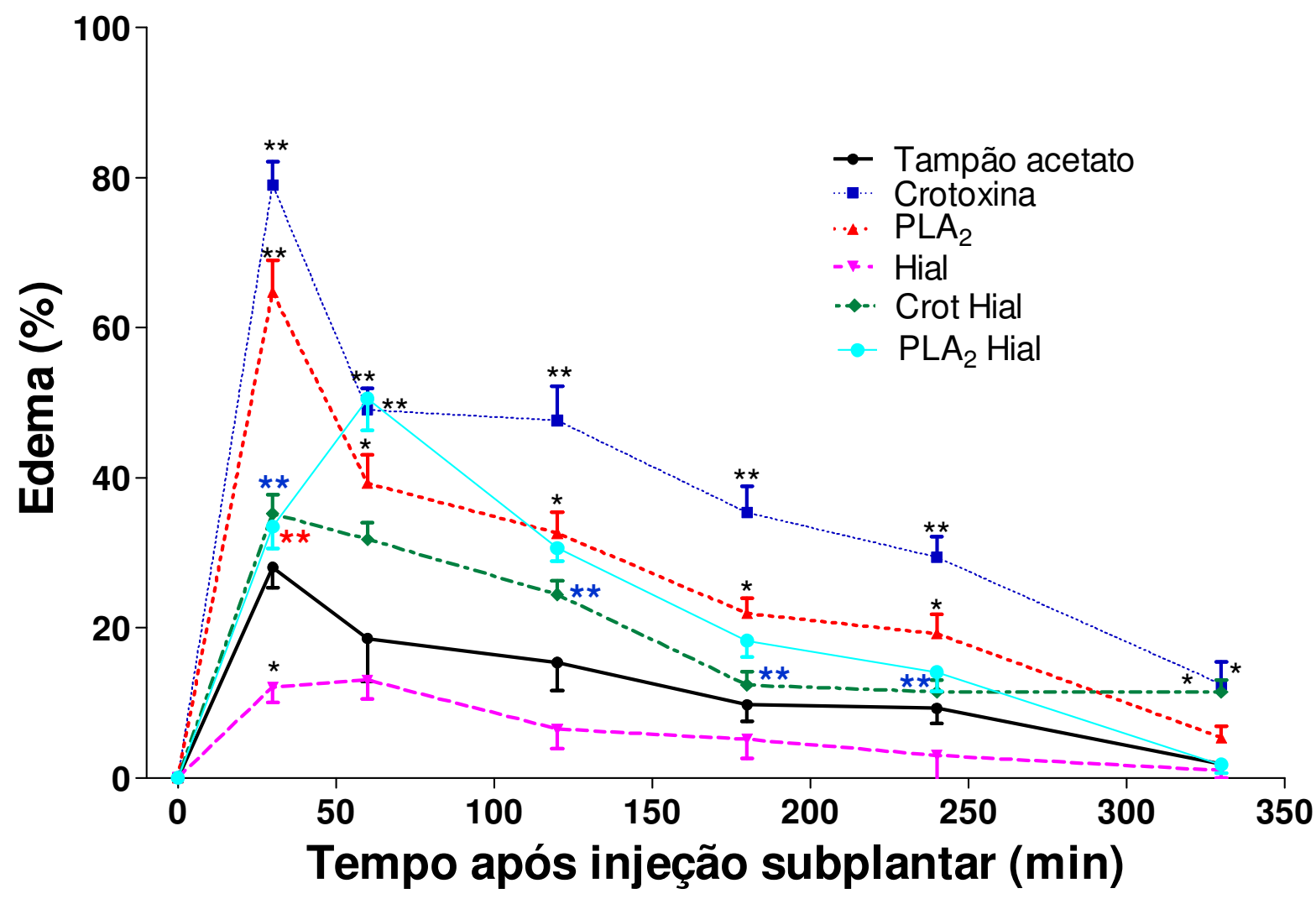

Figura 23. Atividade edematogênica da crotoxina e fosfolipase $A_{2}\left(P L A_{2}\right)$ de Crotalus durissus terrificus na ausência ou presença de hialuronidase (32 UTR/40 $\mu \mathrm{L}$ ). A crotoxina ou PLA $\mathrm{P}_{2}(4$ $\mu \mathrm{g} / 40 \mu \mathrm{L}$ ) e o tampão acetato de sódio $0,05 \mathrm{~mol} / \mathrm{L}, \mathrm{pH} 5,5$, contendo ou não hialuronidase, foram injetados na região subplantar da pata direita traseira de camundongos Swiss machos (28-32 g). Os valores correspondem à média $\pm \operatorname{EPM}(n=5)$. ${ }^{*} p<0,01$ comparado ao controle (tampão acetato) e ${ }^{* *} p<0,001{ }^{* *}$ (preto), comparado ao controle; ** (azul), comparado à crotoxina $\mathrm{e}^{* *}$ (vermelho), comparado à $\mathrm{PLA}_{2}$ ) (ANOVA, seguido do teste de Tukey).

Como se pode observar, para quase todas as soluções injetadas o pico de edema ocorreu em 30 minutos (Fig. 23). Para a crotoxina e a PLA 2 de CdtV observase nesse tempo um aumento superior a $70 \%$ e $60 \%$, respectivamente, no volume da 
pata do animal, embora os resultados não sejam significativos estatisticamente entre os grupos crotoxina versus $\mathrm{PLA}_{2}$.

Comparando os grupos crotoxina + hialuronidase e $\mathrm{PLA}_{2}+$ hialuronidase, observa-se diferença significativa $(p<0,01)$ no tempo de 330 minutos, em que o volume da pata dos animais injetados com $\mathrm{PLA}_{2}+$ hialuronidase retornou ao valor inicial, enquanto no grupo injetado com crotoxina + hialuronidase ainda se apresenta edemaciada. Isso comprova que o complexo crotoxina é mais tóxico que a PLA 2 pura, como relatado na literatura (BON et al., 1979; BREITHAUPT,1976; HENDON; FRAENKEL-CONRAT, 1971; RUBSAMEN; BREITHAUPT; HABERMANN, 1971).

A associação de hialuronidase pura à crotoxina e à $\mathrm{PLA}_{2}$ provocou uma redução do edema induzido pela injeção subplantar das mesmas (50\% com $\mathrm{PLA}_{2}$ e cerca de $30 \%$ com crotoxina) e o pico de atividade edematogênica da PLA $\mathrm{A}_{2}$ ocorreu em 60 minutos (Fig. 23). O edema causado pela crotoxina foi significativamente maior $(p<0,001)$ que os dos grupos controle e hialuronidase. O mesmo foi observado para a $\mathrm{PLA}_{2}$, com $p<0,001$ no tempo de 30 minutos e $p<0,01$ nos demais tempos, comparados ao grupo controle.

A injeção da hialuronidase pura dissolvida em tampão causou edemas menores até mesmo que aqueles registrados para o tampão controle, confirmando sua eficiência em acelerar a dispersão de fluidos nos tecidos. A redução de edema provocada pela hialuronidase, comparada ao grupo controle, foi significativa $(p<0,01)$ no tempo de 30 minutos.

Hialuronidases atuam como efetivos redutores de edema, sendo utilizadas em cirurgias plásticas, angiologia, como auxiliar no tratamento de microvarizes e após cirurgia coronariana (JOHNSSON et al., 1999). Têm sido usadas também para reduzir edema tecidual em parafimose (DEVRIES; MILLER; PACKER, 1996), edema supraglótico (VENKATESK; RAO, 2007) e edema macular diabético (JAVEY; SCHWARTZ; FLYNN, 2012), assim como para facilitar a redução de intussuscepção intestinal (MCGUIRE; BRANNIGAN; O'CONNELL, 2005) e depois de transplante de órgãos (JOHNSSON et al., 1999).

Acredita-se que essa atividade antiedematogênica seja decorrente da hidrólise do substrato, visto que o hialuronan possui alta capacidade de reter água (JOHNSSON et al., 1999) e seu acúmulo tem sido relatado em casos de edema (STAIR et al., 2002). Também foi relatado que a hialuronidase não causa a formação 
de edema e não induz aumento da permeabilidade vascular em pulmão, melhorando a fibrose pulmonar pelo recrutamento de células mesenquimais-símile (BITENCOURT et al., 2011). Foi relatado ainda que a hialuronidase pura não aumenta a permeabilidade vascular (BENDITT et al., 1951) e que este efeito seria devido a um contaminante presente nas preparações contendo hialuronidase (HOUCK; CHANG, 1979; MENZEL; FARR, 1998).

Os resultados obtidos com este ensaio mostraram também que no grupo crotoxina + hialuronidase, os animais apresentaram espasmos e dificuldades motoras após 180 minutos da injeção subplantar. Dois animais estavam mortos decorridos 330 minutos e, no dia seguinte ao ensaio, todos os animais desse grupo estavam mortos. No entanto, no grupo em que foi administrado apenas crotoxina nenhum animal morreu. Esse resultado mostra que a hialuronidase potencializa a ação das toxinas da peçonha. A hialuronidase atuou como "fator de espalhamento" da toxina, causando a morte dos animais por ter aumentado a velocidade de absorção da crotoxina pelos tecidos, causando maior dano ao organismo do animal. Vale ressaltar que os animais dos outros cinco grupos estiveram normais durante todo o ensaio e no dia seguinte.

A propriedade de difundir toxinas da peçonha foi confirmada experimentalmente (TU; HENDON, 1983), potencializando a ação destas nos tecidos da presa/vítima (PUKRITTAYAKAMEE et al., 1988; TU; HENDON, 1983; XU et al., 1982; YINGPRASERTCHAI; BUNYASRISAWAT; RATANABANANGKOON, 2003).

A hialuronidase pode contribuir para o envenenamento local ou sistêmico por acelerar a absorção e difusão da peçonha pelos tecidos da vítima (PUKRITTAYAKAMEE et al., 1988). Estudos realizados por Girish et al. (2004) mostraram qua a hialuronidase, indiretamente, potencializou a miotoxicidade da VRV-PL-VIII, uma miotoxina fosfolipolítica, e a atividade hemorrágica do complexo-I.

As hialuronidases de peçonhas potencializam a toxicidade das peçonhas (GIRISH et al., 2004; TU; HENDON, 1983) e podem causar colapso sistêmico da vítima devida à extensa degradação de hialuronan (HARRISON et al., 2007). Em estudos experimentais, a neutralização da hialuronidase por anticorpos monoclonais ou derivados extraídos de plantas inibiu o dano tecidual, a difusão e os efeitos letais de peçonhas ofídicas (GIRISH et al., 2004.; GIRISH; KEMPARAJU, 2005, 2006; YINGPRASERTCHAI; BUNYASRISAWAT; RATANABANANGKOON, 2003). 
Portanto, o presente trabalho de caracterização da hialuronidase de peçonha de serpente Crotalus durissus terrificus poderá viabilizar a otimização de agentes terapêuticos administrados no quadro de envenenamento ofídico, além de auxiliar na compreensão dos inúmeros processos fisiopatológicos nos quais a enzima está envolvida.

\subsection{Sequenciamento amino-terminal}

A sequência amino-terminal da hialuronidase de Crotalus durissus terrificus obtida, como descrito no item 3.2.7, é apresentada na Figura 24. Esta sequência foi submetida, posteriormente, à análise in silico e depositada no UniProt Knowledgebase (www.uniprot.org) sob o número de acesso B3EWP2.

\section{$1 \quad 11 \quad 21 \quad 31 \quad 41$ MQAKAPMYPN EPFLVFWNAP TTQCRLRYKV DLDLNTFHIV TNAR}

Figura 24. Sequência amino-terminal inicial da hialuronidase de Crotalus durissus terrificus.

Há dois fatores que dificultam a determinação de cada resíduo sucessivo do N-terminal: um deles é que a amplitude dos picos correspondentes ao PTH-aminoácido derivado diminui a cada ciclo, possivelmente pela perda contínua de fragmentos de peptídeos da membrana durante os processos de lavagem e extração em cada ciclo (WAINAINA et al., 2008); o outro é o tamanho da proteína.

Como a hialuronidase é uma proteína grande, como perspectiva futura, objetiva-se proceder à clivagem da enzima com proteases para determinar a sequência de peptídeos internos e usar técnicas complementares, como a espectrometria de massas ou a busca do N-terminal em biblioteca de cDNA, para obter sua sequência primária completa. 


\subsection{Análise in silico}

A caracterização química e estrutural é importante para compreender a interação enzima-substrato e para obtenção de modelos. A busca de proteínas homólogas nos bancos de dados e o alinhamento de suas sequências permitem que fragmentos estruturais conservados sejam identificados e utilizados na modelagem da proteína-alvo (SILVA; SILVA, 2007).

A sequência dos primeiros 44 aminoácidos da região $\mathrm{N}$-terminal da hialuronidase (Fig. 24) foi usada para comparação com sequências depositadas nos principais bancos de dados utilizando o programa BLAST.

$\mathrm{Na}$ análise do alinhamento, a enzima apresentou identidade com as sequências previamente depositadas de hialuronidases de outras espécies de serpentes pertencentes à mesma família Viperidae, sendo cinco destas espécies pertencentes à subfamília Viperinae: Bitis arietans, Cerastes cerastes, Echis carinatus sochureki, Echis ocellatus, Echis pyramidum leakeyi, e uma pertencente à subfamília Crotalinae, Bothropoides neuwiedi pauloensis (denominação anterior Bothrops neuwiedi pauloensis), a mesma subfamília da Crotalus durissus terrificus.

As hialuronidases de Bothrops neuwiedi pauloensis (RODRIGUES et al., 2012) e de Echis carinatus sochureki (HARRISON et al., 2007), obtidas através do transcriptoma da glândula de serpente, são sequências truncadas, ou seja, inativas e, por esse motivo, não foram incluídas no alinhamento.

As sequências de hialuronidases depositadas nos bancos de dados foram comparadas com a sequência da CdtHya1, para verificar a identidade sequencial entre as mesmas. Os alinhamentos foram realizados no programa MultAlin (CORPET, 1988) e as figuras criadas no programa ESPript (GOUET et al., 1999). A Figura 25 apresenta este alinhamento. 
A30VN9 Bitis_arietan A3QVN6 Echis pyramid A3QVN3_Cerastes_cera A3QVN2_Echis_ocellat CdtHyā'Crotalus_dur

A30VN9 Bitis arietan A3QVN6_Echis_pyramid A30VN3 Cerastes cera A3QVN2 Echis_ocellat CdtHya1_Crotalus_dur

A3QVN9_Bitis_arietan A3QVN6_Echis_pyramid A30VN3 Cerastes cera A3QVN2_Echis_ocellat CdtHya1_Crotalus_dur

A3QVN9_Bitis_arietan A3QVN6_Echis_pyramid A3QVN3_Cerastes_cera A3oVN2 Echis ocellat CdtHya1_Crotalus_dur
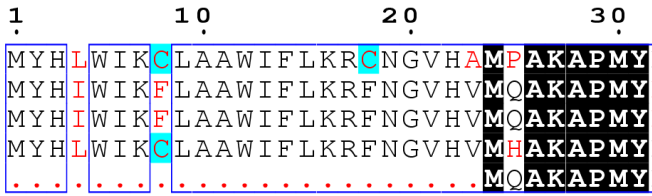

30

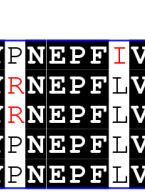

40

$40-50$

70

80

90

100

KTFHIV

KTFHIV

P ND S L SG SVVT IFYPNH LGVYPH IDERGHFFHG I I PONES ITK T LNKSK

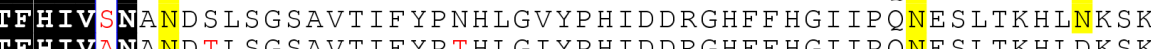
AND T L S G SAVT IFYP THLG IYPH IDDRGHFFHGI I P ONE S LTKH LDKSK TFHIV

$$
120
$$

130

140

150

160

170

SD INRMIP LKT F H L GV I DWENWRPQWDRNWGS KNVYRNRS I QFAKELHPELSEDKI SD INR I I L K A F H L GV IDWENWRPQWDRNWGSKNVYRNRS I QFARDLHPELSEDKI SD I NR I I P LKAF HGLGV I DWENWRPQWDRNWGS KNVYRNRS I QF A RD L HP E LSEDK I

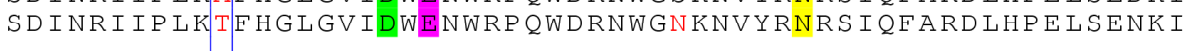

180

190

200

210

220

KRLAKKEYEKAAKSF MRDTLLLAEEMRPNGYWGYYLYPDCQNYDYKTKGDQYTGKCP RRLAKKEYEKAAKS F MRDTLLLAEEMRP D GYWGYYLYPDCQNYDYKTKGDQYTGKCP RRLAKKEYEKAAKSF MRD T LLLAEEMRPDGYWGYYLYPDCQNYDYKTKGDQYTGKCP RRLAKAEYEKAAKS F MRD TLLLAEEMRPDGYWGYYLYPDCQNYDYKTKGDQYTGKCP

$230 \quad 240 \quad 250 \quad 260 \quad 270 \quad 280$

A3QVN9_Bitis_arietan A3QVN6_Echis_pyramid A30VN3 Cerastes_cera A3QVN2_Echis ocellat Cdthyā__Crotalus_dur

DIEMSRNDQLLWLWRDSTALF P NV EIEMSRNDQLLWLWRDSTALFPNV EIEMSRNDQLLWLWRDSTALFPNV DIEMSRNDQLLWLWRESTALFPNV

LE I I LRS S DNA LKFVHHRLKESMR I A SMARED LEI I LRS D D A LKEVHHRLKEAMRIASMARED LE I I LRS S D N L KFVH HRLKEAMR I A SMARED E I I LRS S D NA LKF VHHRLKESMR I A SMARED

290 300 310

320

330

340 YALPVFAYARPFYAYTFEPLTQEDLVTTVGETAAMGAAG IVFWGSMQYASTVDSCQK YALPVFVYYRPFYAYTFEP L TQEDLVT TVGETAAMGAAG IVFWGSMQYASTVDSCQK 30 n6 Bitis ari A30Vis 3 A3QVN2_Echis_ocellat Cdthyaī_Crotālus_dur

A30VN9 Bitis arietan A3QVN6_Echis_pyramid A3QVN3_Cerastes_cera A30VN2 Echis ocellat CdtHya1_Crotalus_dur

350

360

370

380

390

VKTYMNGP LGRYIVNVT TAAKICS H LCRKNGRCVRKHSDSNAF L HFPESFRIMVH VKKYMNGP L GRY IVNVT TAAKICSRVFCRKNGRCVRKHSDSNAFLH LFPESFRIMVY VKKYMNGP L GRY IVNVT TAAKICSRVICRKNGRCVRKHSDSNAF L H LFPESFR I MVY VKKYMNGP L GRY I INVT TAAK I CSHALCRKNGRCVRKH S D S A F L H LF P S F R IMVH

400

$410 \quad 420$

430

440

A3QVN9_Bitis_arietan A3QVN6 Echis pyramid A30VN3 Cerastes cera A3QVN2_Echis_ocellat CdtHyāi_Crotalus_dur

ANA TEKKA I VKGKLE LKD L I Y LRKN F MCQCYQGWKG LYCEEYS I K D I RK I ANA TEKKVIVKGKLELENLIYLRENFMCQCYQGWKGLYCEEYS IKD IRK I ANA TEKKVIVKGKLELENLIYLRENFMCQCYQGWKGLYCEEYS I KD IRK I ANA TEKKVIVKGKLELENLIYLRENF MCQCYQGWQGLYCEEYS I KD I RK I

Figura 25. Alinhamento múltiplo realizado no MultAlin entre hialuronidases de quatro espécies de serpentes e o N-terminal inicial da hialuronidase de Crotalus durissus terrificus. Os aminoácidos em preto delimitam as regiões conservadas (alto consenso) e os aminoácidos em vermelho indicam os resíduos de baixo consenso. Os resíduos de cisteína estão destacados em azul. O resíduo destacado em cor-de-rosa (Glu) participa do mecanismo catalítico. Os resíduos destacados em verde são envolvidos no processo catalítico e são essenciais para o posicionamento do grupo acetamido da carbonila do substrato para a catálise. O resíduo destacado em roxo (Tyr) é responsável pela especificidade para hialuronan. Os resíduos Asn-aaX-Ser/Thr destacados em amarelo correspondem aos possíveis sítios de N-glicosilação preditos através do NetNGlyc 1.0 Server. 
A estrutura primária de hialuronidases de diferentes serpentes é comparada na Figura 25. Observam-se resíduos envolvidos no processo catalítico (destacados em verde) conservados entre as quatro sequências de hialuronidases de serpentes apresentadas na Figura 25, que também são conservados na hialuronidase de abelha.

Nota-se uma elevada identidade sequencial entre as hialuronidases de Bitis arietans, Cerastes cerastes, Echis pyramidum leakeyi, Echis ocellatus e a porção amino-terminal de Crotalus durissus terrificus, sendo encontradas substituições não conservativas apenas em algumas posições (aminoácidos destacados em vermelho na Figura 25). As sequências das hialuronidases destas serpentes foram obtidas por análise do transcriptoma. O peptídeo sinal (resíduos 1 a 20) foi determinado por Harrison et al. (2007) usando os programas SignalP e ConSurf, utilizando a estrutura de abelha como modelo. Entretanto, o alinhamento com CdtHya1, cuja sequência foi obtida da enzima pura que é secretada pela glândula da peçonha da serpente, sugere que os resíduos 21 a 23 também fazem parte do peptídeo sinal.

O resíduo Glu135, que participa do mecanismo catalítico, é conservado nas sequências das hialuronidases alinhadas. Os resíduos Asp133, Tyr206, Trp328 também estão envolvidos no processo catalítico e são essenciais para o posicionamento do grupo acetamido da carbonila do substrato para a catálise (HARRISON et al., 2007). Estes resíduos são conservados entre as hialuronidases de vertebrados (STERN; JEDRZEJAS, 2006). O resíduo Tyr253 é responsável pela especificidade para hialuronan. Se nesta posição houvesse uma Cys253, a enzima teria especificidade para condroitina (STERN; JEDRZEJAS, 2006). O padrão de cisteínas (scaffold) também é conservado entre estas sequências de hialuronidases: Cys47, Cys340, Cys211, Cys227, Cys365, Cys370, Cys376 e Cys429 (HARRISON et al., 2007).

A hialuronidase de Echis ocellatus, embora apresente estrutura primária muito diferente das hialuronidases de abelha e de mamíferos, conserva todos os resíduos catalíticos, posicionais e estruturais, que caracterizam esta classe de hidrolases (HARRISON et al., 2007). Uma elevada identidade sequencial (>95\%) foi observada com sequências de cDNA isoladas da glândula das peçonha de Echis pyramidum leakeyi, Cerastes cerastes cerastes e Bitis arietans (HARRISON et al., 2007), informação que corrobora o observado na Figura 25. 
Especulou-se que o elevado grau de conservação sequencial entre gêneros possibilita o desenvolvimento de um anticorpo poliespecífico para neutralizar a hialuronidase de peçonhas de serpentes (HARRISON et al., 2007).

Para identificar possíveis resíduos específicos em venenos/peçonhas e distintos em mamíferos, Harrison et al. (2007) fizeram a sobreposição das sequências das hialuronidases de peçonhas. Surpreendentemente, os resíduos da fenda catalítica da hialuronidase de Echis ocellatus apresentaram maior identidade com as sequências de hialuronidases de mamíferos do que com hialuronidases de peçonhas de peixes, insetos e víboras. Também observaram motivos conservados apenas na sequência de peçonhas: Arg259, Pro122, Lys217, mas como estão distantes da fenda catalítica, foram considerados sem significância. As regiões amino- e carboxi-terminal de todas as sequências comparadas também apresentaram grande variação: peixes (Synaceia horrida e Tetraodon nigroviridis), insetos (Apis mellifera e Vespula vulgaris), mamíferos (Mus musculus; Rattus norvegicus; Homo sapiens e Canis familiaris) e víboras (Echis ocellatus, Bitis arietans, Cerastes cerastes, Echis pyramidum leakeyi) (HARRISON et al., 2007).

Os primeiros 44 resíduos do N-terminal da hialuronidase de Crotalus durissus terrificus foram alinhados com sequências de hialuronidases de outras quatro serpentes, que possuem 449 aminoácidos. Na Figura 25 observam-se regiões conservadas, destacando em azul os aminoácidos conservados na sequência de aminoácidos destas enzimas. A identificação dos sítios conservados nas hialuronidases poderá auxiliar em estudos futuros de predição da estrutura tridimensional da enzima.

Apesar de a hialuronidase ser encontrada em procariotos e eucariotos, até o presente momento há apenas 40 estruturas tridimensionais de hialuronidase depositadas no PDB (Protein data bank), sendo 85\% delas resolvidas para enzimas de bactérias. Há apenas seis estruturas tridimensionais depositadas para hialuronidases de eucariotos (EC 3.2.1.35): uma da Hyal-1 de Homo sapiens (2PE4), quatro da peçonha de Apis mellifera (1FCQ, 1FCV, 1FCU, 2J88) e uma do alérgeno recombinante Ves v2 de Vespula vulgaris (2ATM).

Ou seja, ainda há infinitas informações a se descobrir sobre hialuronidases. Inclusive a hialuronidase testicular bovina, que foi purificada em 1965 por Soru e Ionescu-Stoian (1965) e teve sua estrutura primária deduzida da sequência de 
peptídeos purificados, até o momento não apresenta estrutura tridimensional resolvida. Por isso esta tese de caracterização funcional e estrutural da hialuronidase é importante, pois traz novas informações sobre hialuronidases e pode auxiliar a compreender melhor a interação da enzima com o substrato, agregando conhecimento na área de envenenamento ofídico.

Quando os cristais obtidos para a hialuronidase de Crotalus durissus terrificus produzirem um padrão de difração de raios-X com boa resolução, possibilitando a determinação da estrutura tridimensional da proteína, será possível avaliar se os resíduos Arg259, Pro122, Lys217 estão conservados e qual o papel deles para a atividade hialuronidásica de peçonhas de serpentes. Além disso, será possível também determinar a significância estrutural dos resíduos Cys 365, Cys370, Cys376 e Cys429 conservados entre as hialuronidases de mamíferos e de serpentes, visto que os mesmos não são encontrados na hialuronidase da peçonha de abelha, que apresenta sequência carboxi-terminal consideravelmente menor que as de transcritos de mamíferos e serpentes (HARRISON et al., 2007).

\subsection{Estudos cristalográficos}

A solução de CdtHya1 foi usada nos ensaios de cristalização, empregando-se o método de difusão de vapor em gota sentada (item 3.2.9).

Alguns pontos de nucleação surgiram na condição número 10 do Crystal Screen I (PEG 4000 30\%, acetato de amônio 0,2 mol/L, acetato de sódio 0,1 mol/L, $\mathrm{pH} 4,6)$ no $4^{\circ}$ dia, mas os cristais cresceram na forma de cluster, semelhantes aos cristais apresentados na Fig. 26A. No $12^{\circ}$ dia constatou-se que o cristal obtido na condição 10 do Crystal Screen I havia crescido e para avaliação da qualidade de organização cristalina foi submetido a experimentos de difração de raios- $X$ no Laboratório Nacional de Luz Síncrotron. Contudo, o padrão de difração obtido era de baixa qualidade, talvez pelo tamanho muito pequeno dos cristais. A técnica de difração de raios- $X$ fornece detalhes a respeito do tamanho, perfeição e orientação dos cristais. A determinação da estrutura cristalográfica permite o mapeamento estrutural de proteínas e é uma das etapas fundamentais para estabelecer a correlação entre estrutura e função da proteína (ZHANG et al., 1999). 
A fim de otimizar as condições iniciais de cristalização foram realizados experimentos de varredura dos parâmetros de cristalização. Alterou-se a quantidade de aditivo acetato de amônio (0 a 0,3 mol/L) e do agente precipitante polietilenoglicol 4000 (PEG 4K) (22 a 32\%) no agente tamponante acetato de sódio 0,1 mol/L, $\mathrm{pH} 4$,6. Foram obtidos cristais na placa de condições otimizadas (Fig. 26).

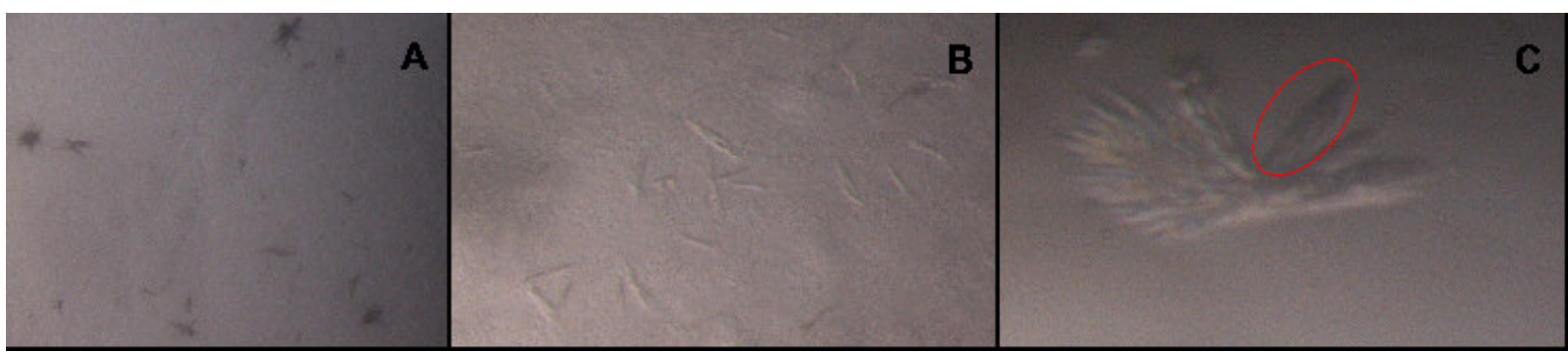

Figura 26. Cristais da hialuronidase da peçonha de Crotalus durissus terrificus. A concentração de hialuronidase utilizada nos ensaios de cristalização foi de aproximadamente $15 \mathrm{mg} / \mathrm{mL}$ (em tampão acetato de sódio $0,05 \mathrm{~mol} / \mathrm{L}, \mathrm{pH} 5,5$ ). Volume da gota $0,5 \mu \mathrm{L}: 0,5 \mu \mathrm{L}$ (solução de proteína : solução de cristalização). Cristal obtido na condição: A) PEG 4000 22\%, acetato de sódio $100 \mathrm{mmol} / \mathrm{L}, \mathrm{pH} 4,6$ (aumento $5 \mathrm{x}$ ); B) PEG 4000 30\%, acetato de sódio 100 mmol/L, pH 4,6 (aumento $11 \mathrm{x}$ ); C) PEG 4000 26\%, acetato de sódio 100 mmol/L pH 4,6 (aumento $11 \mathrm{x}$ ). Ensaios realizados a $22{ }^{\circ} \mathrm{C}$. Imagens fotografadas no $8^{\circ}$ dia. $\mathrm{O}$ círculo vermelho destacado na Figura 26C corresponde ao cristal que se tentou remover "cirurgicamente" para colocar no feixe de raios-X.

Nestes experimentos de cristalização pôde-se concluir que a remoção de acetato de amônio leva uma melhora na qualidade dos cristais, uma vez que observou-se que a hialuronidase precipitou bastante nas condições com acetato de amônio a partir de 0,2 mol/L.

A cristalização, geralmente, é considerada um processo lento, intensivo e com baixas taxas de sucesso. No entanto, a não obtenção de cristais adequados para a difração de raios- $X$ pode ser atribuída à instabilidade da proteína e à presença de glicosilação. Além de obter a proteína com elevado grau de pureza, é necessário fazer uma varredura das condições como $\mathrm{pH}$, temperatura, cofatores $\mathrm{e}$ concentrações de sal e de proteína. Para proteínas com baixo rendimento, é bastante difícil fazer varredura de condições na concentração necessária de proteína (LIU; HSU, 2005). 
Portanto, pode-se considerar que a etapa de cristalização foi extremamente bem sucedida, visto que foi conseguido ultrapassar o obstáculo limitante: uma condição para obtenção de cristal.

Com o objetivo de melhorar a qualidade dos cristais e na expectativa de aumentar o tamanho e diminuir a densidade de nucleação e a taxa de crescimento dos cristais da hialuronidase de Crotalus durissus terrificus, uma nova sequência de purificações foi realizada. Prosseguindo na busca de condições favoráveis à formação de cristais, fez-se varredura com alteração de $\mathrm{pH}$, utilizando acetato de sódio $\mathrm{pH} 4,6$ ou pH 5,5, cacodilato de sódio $\mathrm{pH}$ 6,5 ou HEPES pH 7,5 e alteração da concentração de PEG 4K (22 a 32\%). Em outra varredura, foi variado o PEG; utilizou-se PEG 1K, 4K, 10K e 20K (22 a 32\%) em acetato de sódio 0,1 mol/L, $\mathrm{pH} 4,6$.

Observou-se que a hialuronidase precipitou bastante em pHs próximos ao neutro, sendo a condição de pH 4,6 favorável ao aparecimento de cristais. Com relação ao precipitante, a condição contendo PEG $10 \mathrm{~K}$ foi melhor; no entanto, os cristais continuaram crescendo na forma de ramo (cluster).

Recentemente, na tentativa de aumentar o tamanho e diminuir a nucleação, os microcristais obtidos na condição PEG 10K 24\% em acetato de sódio $100 \mathrm{mmol} / \mathrm{L}, \mathrm{pH} 4,6$, foram submetidos à técnica de microssemeadura (microseeding), contendo no reservatório $500 \mu \mathrm{L}$ de PEG $10 \mathrm{~K}$ (18 a 28\%) em acetato de sódio 0,1 mol/L, $\mathrm{pH} 4,6$. Os experimentos se encontram em fase de avaliação. 
5. CONCLUSÕES 
A hialuronidase hidrolisa hialuronan, componente fundamental da matriz extracelular, e é encontrada praticamente em todas as peçonhas de serpentes. Embora seja pouco expressa, esta enzima é bastante ativa e potencializa a toxicidade da peçonha, podendo causar colapso sistêmico da vítima devido à extensa degradação de hialuronan. Apesar do seu papel fundamental no envenenamento ofídico, a enzima tem sido ignorada, como é evidenciado pelo reduzido número de estudos publicados.

Este trabalho é pioneiro no isolamento e caracterização de uma hialuronidase crotálica, a hialuronidase CdtHya1 presente na peçonha de cascavel Crotalus durissus terrificus. Foi relatada também a primeira condição de cristalização de uma hialuronidase de peçonha ofídica, que é o primeiro passo para a determinação da primeira estrutura tridimensional de hialuronidase de peçonha de serpente.

A CdtHya1 apresentou alta atividade antiedematogênica, possuindo um elevado potencial de aplicação biotecnológica por poder ser utilizada terapeuticamente na redução de edema.

A CdtHya1 também aumentou a difusão e potencializou a ação de toxinas, como evidenciado pela morte de camundongos. Portanto, o uso de inibidores de CdtHya1 poderiam ser utilizados para reduzir os danos teciduais locais, a difusão de toxinas e os efeitos letais das peçonhas.

Os resultados de caracterização funcional e estrutural da hialuronidase apresentados nesta tese poderão contribuir para a otimização de agentes terapêuticos administrados nos casos de envenenamento ofídico, além de auxiliar na compreensão dos inúmeros processos fisiopatológicos nos quais a enzima está envolvida. 
REFERÊNCIAS 


\section{REFERÊNCIAS ${ }^{14}$}

$A B E, Y$. et al. Effect of salt concentration on the pKa of acidic residues in lysozyme. Journal of Biochemistry, Tokyo, v. 118, n. 5, p. 946-952, 1995.

APWEILER, R.; HERMJAKOB, H.; SHARON, N. On the frequency of protein glycosylation, as deduced from analysis of the Swiss-prot database. Biochimica $E t$ Biophysica Acta - General Subjects, Amsterdam, v. 1473, n. 1, p. 4-8, 1999.

ARONSON, N. N. J. R.; DAVIDSON, E. A. Lysosomal hyaluronidase from rat liver. I. Preparation. Journal of Biological Chemistry, Baltimore, v. 242, n. 3, p. 437, 1967a.

ARONSON, N. N. J. R.; DAVIDSON, E. A. Lysosomal hyaluronidase from rat liver. II. Properties. Journal of Biological Chemistry, Baltimore, v. 242, n. 3, p. 441, $1967 \mathrm{~b}$.

ATKINS, G. L.; NIMMO, I. A. A comparison of seven methods for fitting the MichaelisMenten equation. Biochemical Journal, London, v. 149, n. 3, p. 775-777, 1975.

AUTO, H. J. F. Animais peçonhentos. Maceió: EdUFAL, 1999. 114 p.

AZEVEDO-MARQUES, M. M. et al. Myonecrosis, myoglobinuria and acute renal failure induced by South American rattlesnake (Crotalus durissus terrificus) envenomation in Brazil. Toxicon, Oxford, v. 23, p. 631-636, 1985.

BALAZS, E. A. et al. Nomenclature of hyaluronic acid. Biochemical Journal, London, v. 235 , n. 3, p. 903-903, 1986.

BARNHART, B. J.; COX, S. J.; KRAEMER, P. M. Detachment variants of chinese hamster cells - hyaluronic acid as a modulator of cell detachment. Experimental Cell Research, New York, v. 119, n. 2, p. 327-332, 1979.

BARROS, L. C. et al. A new fibrin sealant from Crotalus durissus terrificus venom: applications in medicine. Journal of Toxicology and Environmental Health, Part B, Washington, v. 12, n. 8, p. 553-571, 2009.

BASTOS, E. G. M.; ARAÚJO, A. F. B.; SILVA, H. R. Records of the rattlesnakes Crotalus durissus terrificus (Laurenti) (Serpentes, Viperidae) in the State of Rio de Janeiro, Brazil: a possible case of invasion facilitated by deforestation. Revista Brasileira de Zoologia, São Paulo, v. 22, n. 3, p. 812-815, 2005.

BEAUCHAMP, D. L.; KHAJEHPOUR, M. Probing the effect of water-water interactions on enzyme activity with salt gradients: a case-study using ribonuclease t1. Journal of Physical. Chemistry B, Washington, v. 114, p. 16918-16928, 2010.

${ }^{14}$ Normatizado de acordo com ASSOCIAÇÃO BRASILEIRA DE NORMAS TÉCNICAS. NBR 10520: informação e documentação: apresentação de citações em documentos. Rio de Janeiro, 2002. 
BENCHETRIT, L. C. et al. Purification and characterization of a hyaluronidase associated with a temperate bacteriophage of group-a, type-49 streptococci. Journal of Bacteriology, Washington, v. 134, n. 1, p. 221-228, 1978.

BENDITT, E. P. et al. Evidence that hyaluronidase is not the factor in testicular extract causing increased vascular permeability. Proceedings of the Society for Experimental Biology and Medicine, Malden, v. 77, n. 4, p. 643-646, 1951.

BERNANKE, D. H.; ORKIN, R. W. Hyaluronidase activity in embryonic chick heart muscle and cushion tissues and cells. Developmental Biology, Orlando, v. 106, n. 2, p. 351-359, 1984.

BÉRNILS, R. S. Composição e padrões de distribuição de Caenophidia (Serpentes, Squamata) dos planaltos e serras atlânticas do Sudeste da América do Sul. 2009. 832f. Tese (Doutorado) - Zoologia (Museu Nacional), Universidade Federal do Rio de Janeiro, Rio de Janeiro, 2009.

BÉRNILS, R. S.; COSTA, H. C. (org.). Sociedade Brasileira de Herpetologia. Brazilian reptiles - List of species. 2011. Disponível em: <http://www.sbherpetologia.org.br>. Acesso em: 13 dez. 2011.

BITENCOURT, C. S. et al. Hyaluronidase recruits mesenchymal-like cells to the lung and ameliorates fibrosis. Fibrogenesis Tissue Repair, London, v. 4, n. 1, p. 3, 2011.

BJARNASON, J. B.; FOX, J. W. Hemorrhagic metalloproteinases from snake venoms. Pharmacology and Therapeutics, Oxford, v. 62, n. 3, p. 325-372, 1994.

BOLDRINI-FRANÇA, J. et al. Characterization of hyaluronidase activity from several Viperidae snake venoms and partial isolation of hyaluronidase from Crotalus durissus collilineatus snake venom. In: ANNUAL MEETING OF THE BRAZILIAN SOCIETY FOR BIOCHEMISTRY AND MOLECULAR BIOLOGY, 36, 2007, Salvador. Anais... São Paulo: Sociedade Brasileira de Bioquímica e Biologia Molecular, 2007. N-140, p. 112.

BOLLET, A. J.; BONNER, W. M.; NANCE J. L. Presence of hyaluronidase in various mammalian tissues. Journal of Biological Chemistry, Baltimore, v. 238, n. 11, p. 3522-3527, 1963.

BON, C. et al. Postsynaptic effects of crotoxin and of its isolated subunits. European Journal of Biochemistry, Berlin, v. 99, n. 3, p. 471-481, 1979.

BOOKBINDER, L. H. et al. A recombinant human enzyme for enhanced interstitial transport of therapeutics. Journal of Controlled Release, Amsterdam, v. 114, p. 230241, 2006.

BORDERS, C. L.; RAFTERY, M. A. Purification and partial characterization of testicular hyaluronidase. Journal of Biological Chemistry, Baltimore, v. 243, n. 13, p. 3756-3762, 1968. 
BORDON, K. C. F. et al. Isolation, enzymatic characterization and action as spreading factor of a hyaluronidase from Crotalus durissus terrificus snake venom. Toxicon, Oxford, v. 60, n. 2, p. 197, 2012.

BOWERS, E. M.; RAGLAND, L. O.; BYERS, L. D. Salt effects on beta-glucosidase: pH-profile narrowing. Biochimica et Biophysica Acta-Proteins and Proteomics, Amsterdam, v. 1774, n. 12, p. 1500-1507, 2007.

BRASIL. Ministério da Saúde. Fundação Nacional da Saúde (Funasa). Manual de diagnóstico e tratamento de acidentes por animais peçonhentos. 2. ed. Brasília, DF, 2001. 112 p. Disponível em: <ftp://ftp.cve.saude.sp.gov.br/doc_tec/zoo/manu_ peco01.pdf>. Acesso em: 06 nov. 2010.

BRASIL. Ministério da saúde. Sistema de informação de Agravos de Notificação (Sinan). [2009]. Disponível em: <http://portal.saude.gov.br/portal/saude/ profissional/visualizar_texto.cfm?idtxt=31500>. Acesso em: 29 nov. 2009.

BRASIL. Ministério da Saúde. Secretaria de Vigilância em Saúde. Situação epidemiológica das zoonoses de interesse para a saúde pública. Boletim Eletrônico Epidemiológico, n. 2, abr. 2010, p. 1-24, 2010. Disponível em: $<$ http://portal.saude.gov.br/portal/arquivos/pdf/boletim_eletronico_02_ano10.pdf>.

Acesso em: 06 nov. 2010.

BRECHT, M. et al. Increased hyaluronate synthesis is required for fibroblast detachment and mitosis. Biochemical Journal, London, v. 239, n. 2, p. 445-450, 1986.

BREITHAUPT, H. Enzymatic characteristics of Crotalus phospholipase $A_{2}$ and crotoxin complex. Toxicon, Oxford, v. 14, n. 3, p. 221-233, 1976.

BRENDA. Information on EC 3.2.1.35 - hyaluronoglucosaminidase. [2009]. Disponível em: <http://www.brenda-enzymes.org/php/result_flat.php4?ecno=3.2.1. 35>. Acesso em: 07 nov. 2010.

BRUNISH, R.; MOZERSKY, S. M. Characterization of hyaluronidase isolated from Escherichia freundii. Journal of Biological Chemistry, Baltimore, v. 231, n. 1, p. 291301, 1958.

BULAS DE MEDICAMENTOS NA INTERNET. Hialuronidase. [2010]a. Disponível em: <http://www.bulas.med.br/index.pl?act=search\&q=hialuronidase >. Acesso em: 26 nov. 2010.

BULAS DE MEDICAMENTOS NA INTERNET. Postec. [2010]b. Disponível em: < http://www.bulas.med.br/bula/7268/postec.htm>. Acesso em: 26 nov. 2010.

CAMARA, P. R. S. et al. Inflammatory oedema induced by phospholipases $A_{2}$ isolated from Crotalus durissus sp in the rat dorsal skin: a role for mast cells and sensory C-fibers. Toxicon, Oxford, v. 41, n. 7, p. 823-829, 2003. 
CAMERON, E.; PAULING, L.; LEIBOVITZ, B. Ascorbic acid and cancer: a review. Cancer Research, Baltimore, v. 39, n. 3, p. 663-681, 1979.

CAMILLO, M. A. P. Contribuição ao estudo das giroxinas (enzimas semelhantes à trombina) dos venenos das serpentes brasileiras Lachesis muta muta e Crotalus durissus terrificus. 1998. 75 f. Tese (Doutorado) - Instituto de Pesquisas Energéticas e Nucleares, São Paulo, São Paulo, 1998.

CAMPBELL, J. A.; LAMAR, W. W. The venomous reptiles of Latin America. Ithaca: Cornell University Press, 1989. 425 p.

CAMPBELL, J. A.; LAMAR, W. W. The venomous reptiles of the Western Hemisphere. Ithaca: Cornell University Press, 2004. 870 p. (Comstock Books in Herpetology, v. 2).

CARDOSO, J. L. C. Animais peçonhentos no Brasil: biologia clínica e terapêutica dos acidentes. São Paulo: Sarvier, 2003. 468 p.

CARSON, D. D.; DUTT, A.; TANG, J. P. Glycoconjugate synthesis during early pregnancy: hyaluronate synthesis and funcion. Developmental Biology, Orlando, v. 120, n. 1, p. 228-235, 1987.

CASTANHEIRA, L. E. et al. Purificação e caracterização enzimática e biológica parciais da hialuronidase presente na peçonha de Crotalus durissus collilineatus. In: ENCONTRO INTERNO, 8.; SEMINÁRIO DE INICIAÇÃO CIENTÍFICA DA UNIVERSIDADE FEDERAL DE UBERLÂNDIA, 12., 2008, Uberlândia. Anais... Uberlândia: Swge, 2008. IC2008-0042. Disponível em: <http:// www.icufu.org/anaisufu2008/PDF/IC2008-0042.PDF>. Acesso em: 06 nov. 2010.

CEVALLOS, M. A. et al. Molecular mass determination and assay of venom hyaluronidases by sodium dodecyl sulfate polyacrilamide gel electrophoresis. Toxicon, Oxford, v. 30, n. 8, p. 925-930, 1992.

CHAIN, E.; DUTHIE, E. S. A mucolytic enzyme in testis extracts. Nature, London, v. 144, p. 977-978, 1939.

CHAIN, E.; DUTHIE, E. S. Identity of hyaluronidase and spreading factor. British Journal of Experimental Pathology, London, v. 21, p. 324-338, 1940.

$\mathrm{CHAO}, \mathrm{K}$. L. et al. Structure of human hyaluronidase-1, a hyaluronan hydrolyzing enzyme involved in tumor growth and angiogenesis. Biochemistry, Moscow, v. 46, n. 23, p. 6911-6920, 2007.

CHAVES, F. et al. Pharmacological modulation of edema induced by Lys-49 and Asp-49 myotoxic phospholipases $A_{2}$ isolated from the venom of the snake Bothrops asper (Terciopelo). Toxicon, Oxford, v. 36, n. 12, p. 1861-1869, 1998.

CHEN, T. et al. Unmasking venom gland transcriptomes in reptile venoms. Analytical Biochemistry, New York, v. 311, n. 2, p. 152-156, 2002. 
CHIARINI, E.; VESSONI PENA, T. C. Extração, purificação e caracterização físicoquímica da proteína verde fluorescente recombinante (GFPuv) expressa em Escherichia coli. Brazilian Journal of Pharmaceutical Sciences, São Paulo, v. 39, n. 4, p. 457-466, 2003.

CHIPPAUX, J. P. Snake-bites: appraisal of the global situation. Bulletin of the World Health Organization, Geneve, v. 76, n. 5, p. 515-524, 1998.

CLAUDE, A.; DURAN-REYNALS, F. Chemical properties of the purified spreading factor from testicle. Journal of Experimental Medicine, New York, v. 65, p. 661-671, 1937.

CORPET, F. Multiple sequence aligment with hierarchical clustering. Nucleic Acids Research, London, v. 16, n. 22, p. 10881-10890, 1988.

COSTAL-OLIVEIRA, F. et al. General biochemical and immunological characteristics of the venom from Peruvian scorpion Hadruroides lunatus. Toxicon, Oxford, v. 60, n. 5, p. 934-942, 2012.

CSÓKA, A. B.; FROST, G. I.; STERN, R. Hyaluronidases in tissue invasion. Invasion and Metastasis, Basel, v. 17, n. 6, p. 297-311, 1997.

DA SILVEIRA, R. B. et al. Hyaluronidases in Loxosceles intermedia (brown spider) venom are endo-beta-N-acetyl-D-hexosaminidases hydrolases. Toxicon, Oxford, v. 49, n. 6 , p. 758-768, 2007.

DAVIDSON, T. M.; SCHAFER, S. F.; MOSEMAN, J. Central and South-American pit vipers. Journal of Wilderness Medicine, London, v. 4, n. 4, p. 416-440, 1993.

DEEPAK, A. V. et al. Isolation and characterization of a 29-kDa glycoprotein with antifungal activity from bulbs of Urginea indica. Biochemical and Biophysical Research Communications, San Diego, v. 311, n. 3, p. 735-742, 2003.

DEVRIES, C.R.; MILLER, A.K.; PACKER, M.G. Reduction of paraphimosis with hyaluronidase. Urology, New York, v. 48, n. 3, p. 464-465, 1996.

DI FERRANTE, N. Turbidimetric measurement of acid mucopolysaccharides and hyaluronidase activity. Journal of Biological Chemistry, Baltimore, v. 220, n. 1, p. 303306, 1956.

DOERNER, K. C.; WHITE, B. A. Detection of glycoproteins separated by nondenaturing polyacrylamide-gel electrophoresis using the periodic acid-Schiff stain. Analytical Biochemistry, New York, v. 187, p. 147-150, 1990.

DOS SANTOS, M. C. et al. Caracterizacion de las actividades biologicas de los venenos 'amarillo' y 'blanco' de Crotalus durissus ruruima comparados con el veneno de Crotalus durissus terrificus. Poder neutralizante de los antivenenos frente a los 
venenos de Crotalus durissus ruruima. Toxicon, Oxford, v. 31, n. 11, p. 1459-1469, 1993.

DUBOIS, M. et al. Colorimetric method for determination of sugars and related substances. Analytical Chemistry, Washington, v. 28, n. 3, p. 350-356, 1956.

DUNN, A. L. et al. Hyaluronidase: a review of approved formulations, indications and off-label use in chronic pain management. Expert Opinion on Biological Therapy, London, v. 10, n. 1, p. 127-131, 2010.

DURAN-REYNALS, F. On the spontaneous immunization of rabbits to vaccine virus. Journal of Immunology, Baltimore, v. 20, p. 389-391, 1931.

EBERHART, A. H.; WEILER, C. R.; ERIE, J. C. Angioedema related to the use of hyaluronidase in cataract surgery. American Journal of Ophthalmology, Chicago, v. 138, n. 1, p. 142-143, 2004.

EBO, D. et al. Flow-assisted diagnosis of anaphylaxis to hyaluronidase. Allergy, Copenhagen, v. 60, n. 10, p. 1333-1334, 2005.

EDMAN, P.; BEGG, G. A protein sequenator. European Journal of Biochemistry, Berlin, v. 1, n. 1, p. 80-91, 1967.

ELLIOTT, W. B. Chemistry and immunology of reptilian venoms. In: GANS, C. (Ed.). Biology of the Reptilia. London: Academic Press, 1978. v. 8. p. 163.

EL-SAFORY, N.S.; FAZARY, A.E.; LEE, C.K. Hyaluronidases, a group of glycosidases: Current and future perspectives. Carbohydrate Polymers, v. 81, p.165181, 2010.

FAURE, G.; BON, C. Several isoforms of crotoxin are present in individual venoms from the South American rattlesnake Crotalus durissus terrificus. Toxicon, Oxford, v. 25, n. 2, 1987, p. 229-234, 1987.

FAVORITO, L. A. et al. Treatment of phimosis: structural analysis of prepuce in patients submitted to topical treatment with betamethasone in association with hyaluronidase. European Urology Supplements, Amsterdam, v. 7, n. 3, p. 704, 2008.

FECHNER, P. U.; WICHMANN, W. Intraocular use of hyaluronidase to dissolve sodium hyaluronic acid. Journal of Refractive Surgery, Thorofare, v. 13, n. 6, p. 502503, 1997.

FENWICK, A. M. et al. Morphological and molecular evidence for phylogeny and classification of South American pitvipers, genera Bothrops, Bothriopsis, and Bothrocophias (Serpentes: Viperidae). Zoological Journal of the Linnean Society, London, v. 156, n. 3, p. 617-640, 2009. 
FISHER, B. M.; SCHULTZ, L. W.; RAINES, R. T. Coulombic effects of remote subsites on the active site of ribonuclease A. Biochemistry, Moscow, v. 37, n. 50, p. 17386-17401, 1998.

FISZER-SZAFARZ, B. Hyaluronidase polymorphism detected by polyacrylamide gel electrophoresis. Application to hyaluronidases from bacteria, slime molds, bee and snake venoms, bovine testes, rat liver lysosomes, and human serum. Analytical Biochemistry, New York, v. 143, n. 1, p. 76-81, 1984.

FISZER-SZAFARZ, B.; LITYNSKA, A.; ZOU, L. M. Human hyaluronidases: electrophoretic multiple forms in somatic tissues and body fluids - Evidence for conserved hyaluronidase potential $\mathrm{N}$-glycosylation sites in different mammalian species. Journal of Biochemical and Biophysical Methods, Amsterdam, v. 45, n. 2, p. 103-116, 2000.

FORRESTER, J. V.; BALAZS, E. A. Inhibition of phagocytosis by high molecular weight hyaluronate. Immunology, Oxford, v. 40, n. 3, p. 435-446, 1980.

GAGNEUX, P.; VARKI, A. Evolutionary considerations in relating oligosaccharide diversity to biological function. Glycobiology, Oxford, v. 9, n. 8, p. 747-755, 1999.

GAUTAM, M.; BENSON, C. J.; SLUKA, K. A. Increased response of muscle sensory neurons to decreases in $\mathrm{pH}$ after muscle inflammation. Neuroscience, Oxford, v. 170, p. 893-900, 2010.

GIRISH, K. S.; KEMPARAJU, K. Inhibition of Naja naja venom hyaluronidase by plant-derived bioactive components and polysaccharides. Biochemistry, Moscow, v. 70, n. 8, p. 948-952, 2005.

GIRISH, K.; KEMPARAJU, K. Inhibition of Naja naja venom hyaluronidase: role in the management of poisonous bite. Life Sciences, Amsterdam, v. 78, n. 13, p. 1433-40, 2006.

GIRISH, K. S.; KEMPARAJU, K. The magic glue hyaluronan and its eraser hyaluronidase: a biological overview. Life Sciences, Amsterdam, v. 80, n. 21, p. 1921-1943, 2007.

GIRISH, K. S.; KEMPARAJU, K. Overlooked issues of snakebite management: time for strategic approach. Current Topics in Medicinal Chemistry, Hilversum, v. 11, n. 20 , p. $2494-2508,2011$.

GIRISH, K. S. et al. Snake venom hyaluronidase: An evidence for isoforms and extracellular matrix degradation. Molecular and Cellular Biochemistry, The Hague, v. 240, n. 1-2, p. 105-110, 2002.

GIRISH, K. S. et al. Isolation and characterization of hyaluronidase a "spreading factor" from Indian cobra (Naja naja) venom. Biochimie, Paris, v. 86, n. 3, p. 193-202, 2004. 
GIRISH, K. S. et al. Hyaluronidase inhibitors: a biological and therapeutic perspective. Current Medicinal Chemistry, Schiphol, v. 16, n. 18, p. 2261-2288, 2009.

GLOBAL SNAKE BITE INITIATIVE. Snakebite burden around the world. [2010]. Disponível em: <http://www.snakebiteinitiative.org/>. Acesso em: 22 set. 2010.

GMACHL, M. et al. The human sperm protein $\mathrm{PH}-20$ has hyaluronidase activity. FEBS Letters, Amsterdam, v. 336, n. 3, p. 545-548, 1993.

GOUET, P. et al. ESPript: analysis of multiple sequence alignments in PostScript. Bioinformatics, Oxford, v. 15, n. 4, p. 305-308, 1999.

GOUVEIA, A. I. D. et al. Identification and partial characterization of hyaluronidases in Lonomia obliqua venom. Toxicon, Oxford, v. 45, n. 4, p. 403-410, 2005.

GRECO, W. R.; HAKALA, M. T. Evaluation of methods for estimating the dissociation-constant of tight binding enzyme-inhibitors. Journal of Biological Chemistry, Baltimore, v. 254, n. 23, p. 12104-12109, 1979.

GUTIERREZ, J. M.; RUCAVADO, A. Snake venom metalloproteinases: Their role in the pathogenesis of local tissue damage. Biochimie, Paris, v. 82, n. 9-10, p. 841-850, 2000.

GUTIERREZ, V. P. et al. Crotalphine induces potent antinociception in neuropathic pain by acting at peripheral opioid receptors. European Journal of Pharmacology, Amsterdam, v. 594, n. 1-3, p. 84-92, 2008.

HABERMANN, E.; BREITHAUPT, $H$. The crotoxin complex - an example of biochemical and pharmacological protein complementation. Toxicon, Oxford, v. 16, n. 1, p. 19-30, 1978.

HAKANSSON, L.; VENGE, P. The combined action of hyaluronic acid and fibronectin stimulates neutrophil migration. Journal of Immunology, Baltimore, v. 135, n. 4, p. 2735-2739, 1985.

HANES, C. S. Studies on plant amylases. I. The effect of starch concentration upon the velocity of hydrolysis by the amylase of germinated barley. Biochemical Journal, London, v. 26, n. 5, p. 1406-1421, 1932.

HAROONI, M. et al. Efficacy and safety of enzymatic posterior vitreous detachment by intravitreal injection of hyaluronidase. Retina, Philadelphia, v. 18, n. 1, p. 16-22, 1998.

HARRISON, R. A. et al. Identification of cDNAs encoding viper venom hyaluronidases: Cross-generic sequence conservation of full-length and unusually short variant transcripts. Gene, Amsterdam, v. 392, p.22-33, 2007. 
HASCALL, V. C.; LAURENT, T. C. Hyaluronan: structure and physical properties. 1997. Disponível em: <http://www.glycoforum.gr.jp/science/hyaluronan/HA01/ HA01E.html>. Acesso em: 14 nov. 2010.

HENDON, R. A.; FRAENKEL-CONRAT, H. Biological roles of two components of crotoxin. Proceedings of the National Academy of Sciences of the United States of America, Washington, v. 68, p. 1560-1563, 1971.

HOFFMAN, D. C.; DURAN-REYNALS, F. The influence of testicle extract on the intradermal spread of injected fluids and particles. Journal of Experimental Medicine, New York, v. 53, n. 3, p. 43-50, 1931.

HOTEZ, P. et al. Hyaluronidases of the gastrointestinal invasive nematodes Ancylostoma caninum and Anisakis simplex - possible functions in the pathogenesis of human zoonoses. Journal of Infectious Diseases, Chicago, v. 170, n. 4, p. 918926, 1994.

HOUCK, J. C.; CHANG, C. M. Permeability factor contaminating hyaluronidase preparations. Inflammation, New York, v. 3, n. 4, p. 447-451, 1979.

HOVINGH, P.; LINKER, A. Hyaluronidase activity in leeches (Hirudinea). Comparative Biochemistry and Physiology B-Biochemistry \& Molecular Biology, Oxford, v. 124, n. 3, p. 319-326, 1999.

HURTADO, L. et al. Aislamiento y algunas propiedades bioquímicas de una hialuronato glucanohidrolasa del veneno de la serpiente Lachesis muta "shushupe". Revista de la Sociedad Quimica del Perú, Lima, v. 73, n. 74, p. 226-234, 2007.

HYNES, W. L.; WALTON, S. L. Hyaluronidases of gram-positive bacteria. FEMS Microbiology Letters, Oxford, v. 183, n. 2, p. 201-207, 2000.

IKEGAMI-KAWAI, M.; TAKAHASHI, T. Microanalysis of hyaluronan oligosaccharides by polyacrylamide gel electrophoresis and its application to assay of hyaluronidase activity. Analytical Biochemistry, New York, v. 311, n. 2, p. 157-165, 2002.

IWANAGA, S.; SUZUKI, T. Enzymes in snake venom. In: LEE, C. Y. (Ed.). Snake venoms. Berlin: Springer-Verlag, 1979a. p. 95.

IWANAGA, S.; SUZUKI, T. Enzymes in snake venom. In: LEE, C. Y. (Ed.). Snake venoms. Berlin: Springer-Verlag, 1979b. p. 99.

JANCARIK, J.; KIM, S. H. Sparse matrix sampling: a screening method for crystallization of proteins. Journal of Applied Crystallography, Copenhagen, v. 24, p. 409-411, 1991.

JAVEY, G.; SCHWARTZ, S.G.; FLYNN, H.W. JR. Emerging pharmacotherapies for diabetic macular edema. Experimental Diabetes Research, New York, v. 2012, p. 548732, 2012. 
JEDRZEJAS, M. J.; STERN, R. Structures of vertebrate hyaluronidases and their unique enzymatic mechanism of hydrolysis. Proteins: Structure, Function and Bioinformatics, New York, v. 61, n. 2, p. 227-238, 2005.

JIANG, D.; LIANG, J.; NOBLE, P. W. Hyaluronan in tissue injury and repair. Annual Review of Cell and Developmental Biology, Palo Alto, v. 23, p. 435-461, 2007.

JOHNSSON, C. et al. Edema treatment during cardiac allograft rejection. Journal of Heart and Lung Transplantation, St. Louis, v. 18, n. 12, p. 1238-1242, 1999.

JORGE, M. T.; RIBEIRO, L. A. Acidentes por serpentes peçonhentas do Brasil. Revista da Associação Médica Brasileira, São Paulo, v. 36, n. 2, p. 66-77, 1990.

KEMENY, D. M. et al. The purification and characterization of hyaluronidase from the venom of the honey bee, Apis mellifera. European Journal of Biochemistry, Berlin, v. 139, n. 2, p. 217-223, 1984.

KEMPARAJU, K.; GIRISH, K. S.; NAGARAJU, S. Hyaluronidases, a neglected class of glycosidases from snake venom: beyond a spreading factor. Handbook of venoms and toxins of reptiles., p. 237-258, 2010.

KNUDSON, C. B.; TOOLE, B. P. Hyaluronate cell interations during differentiation of chich-embryo limb mesoderm. Developmental Biology, Orlando, v. 124, n. 1, p. 8290, 1987.

KONNO, K. et al. Crotalphine, a novel potent analgesic peptide from the venom of the South American rattlesnake Crotalus durissus terrificus. Peptides, New York, v. 29, n. 8, p. 1293-1304, 2008.

KREIL, G. Hyaluronidases - A group of neglected enzymes. Protein Science, New York, v. 4, n. 9, p. 1666-1669, 1995.

KUBELKA, V.; ALTMANN, F.; MARZ, L. The asparagine-linked carbohydrate of honeybee venom hyaluronidase. Glycoconjugate Journal, London, v. 12, n. 1, p. 7783, 1995.

KUDO, K.; TU, A. T. Characterization of hyaluronidase isolated from Agkistrodon contortrix contortrix (southern copperhead) venom. Archives of Biochemistry and Biophysics, New York, v. 386, n. 2, p. 154-162, 2001.

LAEMMLI, U. K. Cleavage of structural protein during the assembly of the head of bacteriophage "T4". Nature, London, v. 227, 680-685, 1970.

LAURENT, T. The biology of hyaluronan - introduction. Ciba Foundation Symposia, Amsterdam, v. 143, p. 1-5, 1989.

LEHNINGER, A. L. Bioquímica: enzimas. São Paulo: Edgard Blücher, 1976. p. 90211. 
LEONARDI, G. R.; GASPAR, L. R.; MAIA-CAMPOS, M. B. G. Study of pH variation on the skin using cosmetic formulation $s$ with and without vitamins $A, E$ or ceramide: by a non-invasive method. Anais Brasileiros de Dermatologia, Rio de Janeiro, v. 77, n. 5, p. 563-569, 2002.

LI, M. W. et al. Importance of glycosylation and disulfide bonds in hyaluronidase activity of macaque sperm surface PH-20. Journal of Andrology, Philadelphia, v. 23, n. 2, p. 211-219, 2002.

LINEWEAVER, H.; BURK, D. The determination of enzyme dissociation constants. Journal of the American Chemical Society, Washington, v. 56, p. 658-666, 1934.

LIU, H. L.; HSU, J. P. Recent developments in structural proteomics for protein structure determination. Proteomics, Weinheim, v. 5, n. 8, p. 2056-2068, 2005.

LOKESHWAR, V. B. et al. Association of elevated levels of hyaluronidase, a matrixdegrading enzyme, with prostate cancer progression. Cancer Research, Baltimore, v. 56, n. 3, p. 651-657, 1996.

LOKESHWAR, V. B. et al. Regulation of hyaluronidase activity by alternative mRNA splicing. Journal of Biological Chemistry, Baltimore, v. 277, n. 37, p. 33654-33663, 2002.

LU, G.; KOCHOUMIAN, L.; KING, T. P. Sequence identity and antigenic crossreactivity of white face hornet venom allergen, also a hyaluronidase, with other proteins. Journal of Biological Chemistry, Baltimore, v. 270, n. 9, p. 4457-4465, 1995.

MAGALHÃES, M. R.; DA SILVA, N.J.; ULHOA, C.J. A hyaluronidase from Potamotrygon motoro (freshwater stingrays) venom: isolation and characterization. Toxicon, Oxford, v. 51, n. 6, p. 1060-1067, 2008.

MAHADESWARASWAMY, Y. $\mathrm{H}$. et al. Daboia russelli venom hyaluronidase: purification, characterization and inhibition by beta-3-(3-Hydroxy-4-Oxopyridyl) alphaamino-propionic acid. Current Topics in Medicinal Chemistry, Hilversum, v. 11, n. 20, p. 2556-2565, 2011.

MARKOVIĆ-HOUSLEY, Z. et al. Crystal structure of hyaluronidase, a major allergen of bee venom. Structure, London, v. 8, n. 10, p. 1025-1035, 2000.

MARQUES, O. A. V.; ABE, A. S.; MARTINS, M. Estudo diagnóstico da diversidade de répteis do Estado de São Paulo. In: CASTRO, R. M. C. (Org.). Biodiversidade do Estado de São Paulo: síntese do conhecimento ao final do século XX. São Paulo: FAPESP, 1998. p. 29-38.

MARTINDALE: the extra pharmacopoeia. 28th. ed. London: Pharmaceutical Press, 1982. $650 \mathrm{p}$.

MCCLEAN, D.; HALE, C. W. Mucinase and tissue permeability. Nature, London, v. 145 , p. $867-868,1940$. 
MCGUIRE, B.; BRANNIGAN, A. E.; O'CONNELL, P. R. Hyaluronidase assisted reduction of intestinal intussusception; a novel application. Irish Medical Journal, Dublin, v. 98, n. 5, p. 146-147, 2005.

MELGAREJO, A. R. Serpentes peçonhentas: principais grupos, identificação, veneno, acidentes e primeiros socorros. [2003]. Disponível em: <http://www.ivb.ri.gov.br/palestras/roteiro.doc > . Acesso em: 01 nov. 2010.

MENZEL, E. J.; FARR, C. Hyaluronidase and its substrate hyaluronan: biochemistry, biological activities and therapeutic uses. Cancer Letters, Virginia, v. 131, n. 1, p. 3$11,1998$.

MERHEB-DINI, C. et al. Biochemical and functional characterization of a metalloprotease from the thermophilic fungus Thermoascus aurantiacus. Journal of Agricultural and Food Chemistry, Washington, v. 57, n. 19, p. 9210-9217, 2009.

METZ, M. et al. Mast cells can enhance resistance to snake and honeybee venoms. Science, New York, v. 313, n. 5786, p. 526-530, 2006.

MEYER, K.; PALMER, J. W. The polysaccharide of the vitreous humor. Journal of Biological Chemistry, Baltimore, v. 107, p. 629-634, 1934.

$\mathrm{MIO}$, K. et al. Detecting hyaluronidase and hyaluronidase inhibitors: hyaluronansubstrate gel and -inverse substrate gel techniques. In: IOZZO, R. V. (Ed.). Proteoglycan protocols. Philadelphia: Humana Press, 2001. v. 171, cap. 39, p. 391397.

MOREY, S. S. et al. Purification and properties of hyraluronidase from Palamneus gravimanus (Indian black scorpion) venom. Toxicon, Oxford, v. 47, n. 2, p. 188-195, 2006.

MURPHY, P. M.; GAULT, D. T. Treatment of extravasation injury. Anaesthesia, London, v. 45, n. 7, p. 600, 1990.

MUSEU INSTITUTO BUTANTAN. Serpentes peçonhentas. [2010]. Disponível em: $<$ http://images.pauloadsalte.multiply.multiplycontent.com/attachment/0/SylhjgooCkU AAG31-aE1/Serpentes\%20Pe\%C3\%A7onhentas.pdf?nmid=304444524>. Acesso em 26 set. 2010.

NAGARAJU, S.; DEVARAJA, S.; KEMPARAJU, K. Purification and properties of hyaluronidase from Hippasa partita (funnel web spider) venom gland extract. Toxicon, Oxford, v. 50, n. 3, p. 383-393, 2007.

NECAS, J. et al. Hyaluronic acid (hyaluronan): a review. Veterinární Medicina, Praha, v. 53, n. 8, p. 397-411, 2008.

NOBLE, P. W. Hyaluronan and its catabolic products in tissue injury and repair. Matrix Biology, Stuttgart, v. 21, n. 1, p. 25-29, 2002. 
OHYA, T.; KANEKO, Y. Novel hyaluronidase from Streptomyces. Biochimica et Biophysica Acta, Amsterdam, v. 198, n. 3, p. 607-609, 1970.

OWEN, M. D. The venom system and venom hyaluronidase of the African honeybee (Apis mellifera adansonii). Toxicon, Oxford, v. 21, n. 1, p. 171-174, 1983.

OZEGOWSKI, J. H. et al. Purification and characterization of hyaluronidase from Streptococcus agalactiae. Zentralblatt Fur Bakteriologie: International Journal of Medical Microbiology Virology Parasitology and Infectious Diseases, Sttutgard, v. 280, n. 4, p. 497-506, 1994.

PARK, C.; RAINES, R. T. Origin of the 'inactivation' of ribonuclease A at low salt concentration. FEBS Letters, Amsterdam, v. 468, n. 2-3, p. 199-202, 2000.

PEARCE, R. H. The turbidimetric estimation of hyaluronate. Biochemical Journal, London, v. 55, n. 3, p. 472-477, 1953.

PEREIRA, S. C.; RIBEIRO, V. F. Infusão subcutânea é boa opção em cuidados paliativos. Intravenous, n. 16, p. 5, jan.-mai. 2006. Disponível em: $<$ http://www.bd.com/brasil/periodicos/intravenous/Intravenous_Ed16_VF.pdf>. Acesso em 15 nov. 2010.

PESSINI, A. C. et al. A hyaluronidase from Tityus serrulatus scorpion venom: isolation, characterization and inhibition by flavonoids. Toxicon, Oxford, v. 39, n. 10, p. 1495-1504, 2001.

PICHERT, A. et al. Characterization of the interaction of interleukin-8 with hyaluronan, chondroitin sulfate, dermatan sulfate and their sulfated derivatives by spectroscopy and molecular modeling. Glycobiology, Oxford, v. 22, n. 1, p. 134-145, 2012.

PILLWEIN, K. et al. Hyaluronidase additional to standard chemotherapy improves outcome for children with malignant brain tumors. Cancer Letters, Amsterdam, v. 131, n. 1, p. 101-108, 1998.

PIRRELLO, R., CHEN, C. T.; THOMAS, S. H. Initial experiences with subcutaneous recombinant human hyaluronidase. Journal of Palliative Medicine, Larchmont, v. 10, n. 4, p. 861-4, 2007.

PODYMA, K. A. et al. Difference of hyaluronidase produced by human tumor cell lines with hyaluronidase present in human serum as revealed by zymography. Biochemical and Biophysical Research Communications, New York, v. 241, n. 2, p. 446-452, 1997.

$\mathrm{POH}, \mathrm{C} . \mathrm{H}$. et al. Purification and partial characterization of hyaluronidase from stonefish (Synanceja horrida) venom. Comparative Biochemistry and Physiology - B - Biochemistry and Molecular Biology, Oxford, v. 101, n. 1-2, p. 159-163, 1992. 
PRADO-FRANCESCHI, J.; VITAL BRAZIL, O. Convulxin, a new toxin from the venom of the South American rattlesnake Crotalus durissus terrificus. Toxicon, Oxford, v. 19, n. 6, p. 875-887, 1981.

PRITCHARD, D. G. et al. Characterization of the group B streptococcal hyaluronate lyase. Archives of Biochemistry and Biophysics, New York, v. 315, n. 2, p. 431-437, 1994.

PUKRITTAYAKAMEE, S. et al. The hyaluronidase activities of some Southeast Asian snake venoms. Toxicon, Oxford, v. 26, n. 7, p. 629-637, 1988.

RAMANAIAH, M.; PARTHASARATHY, P. R.; VENKAIAK, B. Isolation and characterization of hyaluronidase from scorpion (Heterometrus fulvipes) venom. Biochemistry International, Sydney, v. 20, n. 2, p. 301-310, 1990.

RATELSLANGEN. Crotalus durissus - South American rattlesnake. [2010]. Disponível em: <http://www.ratelslangen.nl/gallery/Crotalus_durissus_South_ American_rattlesnake/>. Acesso em: 26 set. 2010.

RAUTELA, G. S.; ABRAMSON, C. Crystallization and partial characterization of Staphylococcus aureus hyaluronate lyase. Archives of Biochemistry and Biophysics, New York, v. 158, n. 2, p. 687-694, 1973.

RODRIGUES, S. R. et al. Combined snake venomics and venom gland transcriptomic analysis of Bothropoides pauloensis. Journal of Proteomics, Amsterdam, v. 75, n. 9, p. 2707-2720, 2012.

RUBSAMEN, K.; BREITHAUPT, H.; HABERMANN, E. Biochemistry and pharmacology of crotoxin complex. Subfractionation and recombination of crotoxin complex. Naunyn-Schmiedebergs Archiv Fur Pharmakologie, Berlin, v. 270, n. 3, p. 274-278, 1971.

SCARABOTTO, L. B.; RIESCO, M. L. G. Use of hyaluronidase to prevent perineal trauma during spontaneous delivery: A pilot study. Journal of Midwifery \& Women's Health, New York, v. 53, n. 4, p. 353-361, 2008.

SCHMID-WENDTNER, M. H.; KORTING, H. C. The pH of the skin surface and its impact on the barrier function. Skin Pharmacology and Physiology, Basel, v. 19, n. 6, p. 296-302, 2006.

SCOPES, R. K. Measurement of protein by spectrophotometry at $205 \mathrm{~nm}$. Analytical Biochemistry, New York, v. 59, n. 1, p. 277-282, 1974.

SEKI, C.; VIDAL, J. C.; BARRIO, A. Purification of gyroxin from a south-american rattlesnake (Crotalus durissus terrificus) venom. Toxicon, Oxford, v. 18, n. 3, p. 235247, 1980. 
SEPPÄLÄ, U. R. et al. Analysis of N-glycosylation in Vespula vulgaris hyaluronidase Ves v 2. Journal of Allergy and Clinical Immunology, St. Louis, v. 117, n. 2, p. S119S119, 2006.

SHIMIZU, M. T. et al. Hyaluronidase and chondroitin sulphatase production by different species of Candida. Journal of Medical and Veterinary Mycology, Oxfordshire, v. 33, n. 1, p. 27-31, 1995.

SILBERT, J. E.; NAGAI, Y.; GROSS, J. Hyaluronidase from tadpole tissue. Journal of Biological Chemistry, Baltimore, v. 240, n. 4, p. 1509, 1965.

SILVA, V. B. D.; SILVA, C. H. T. P. Modelagem molecular de proteínas-alvo por homologia estrutural. Revista Eletrônica de Farmácia, Goiânia, v. 4, n. 1, p. 15-26, 2007.

SILVA, F. S. A importância hematofágica e parasitológica da saliva dos insetos hematófagos. Revista Trópica - Ciências Agrárias e Biológicas, Chapadinha, v. 3, n. 3, p. 3-17, 2009.

SKOV, L. K. et al. Structure of recombinant Ves v 2 at $2.0 \AA$ resolution: structural analysis of an allergenic hyaluronidase from wasp venom. Acta Crystallographica Section D - Biological Crystallography, Copenhagen, v. 62, p. 595-604, 2006.

SOERENSEN, B. Animais peçonhentos: principais serpentes de interesse médico. Reconhecimento, distribuição geográfica no continente americano. São Paulo: Atheneu, 1990. 138 p.

SOLDATOVA, L. N. et al. The role of glycosylation in the $\lg E$ binding of the major honeybee allergen, hyaluronidase. Journal of Allergy and Clinical Immunology, St. Louis, v. 109, n. 1, p. S134-S134, 2002.

SORU, E.; IONESCU-STOIAN, F. The purification of testicular hyaluronidase by chromatography on a mixed column. Journal of Chromatography, Amsterdam, v. 17, n. 3, p. 538, 1965.

SOUZA, D. H. F. et al. The disintegrin-like domain of the snake venom metaloprotease alternagin inhibits alpha 2 beta 1 integrin-mediated cell adhesion. Archives of Biochemistry and Biophysics, New York, v. 384, n.2, p.341-350, 2000.

STAIR, S. et al. Mystixin peptides reduce hyaluronan deposition and edema formation. European Journal of Pharmacology, Amsterdam, v. 450, n. 3, p. 291-296, 2002.

STERN, R. Midnight footprints in the watermelon patch. Matrix Biology, Stuttgart, v. 27, n. 8, p. 651-2, Oct. 2008.

STERN, R.; JEDRZEJAS, M. J. Hyaluronidases: their genomics, structures, and mechanisms of action. Chemical Reviews, Washington, v. 106, n. 3, p. 818-839, 2006. 
STERN, R.; CSÓKA, A. B. Mammalian hyaluronidases. 2000. Disponível em: $<$ http://www.glycoforum.gr.jp/science/hyaluronan/hapdf/HA15.pdf>. Acesso em 09 nov. 2010.

TAM, Y. C.; CHAN, E. C. S. Purification and characterization of hyaluronidase from oral Peptostreptococcus species. Infection and Immunity, Washington, v. 47, n. 2, p. 508-513, 1985.

TAMBOURGI, D. V. Envenenameno por serpentes: doença negligenciada afetando países em desenvolvimento. In: REUNIÃO ANUAL DA SOCIEDADE BRASILEIRA PARA O PROGRESSO DA CIÊNCIA (SBPC), 62, 2010, Natal. Anais... Disponível em:<http://www.sbpcnet.org.br/livro/62ra/conferencias/CO\%20Denise\%20V\%20Tam bourgi.pdf>. Acesso em: 27 set. 2010.

TEIXEIRA, C. F. et al. Inflammatory effects of snake venom myotoxic phospholipases A. Toxicon, Oxford, v. 42, n. 8, p. 947-962, 2003.

TEIXEIRA, C. F. et al. Inflammatory effects of snake venom metalloproteinases. Memórias do Instituto Oswaldo Cruz, Rio de Janeiro, v. 100, p. 181-184, 2005.

TOIDA, T. et al. Inhibition of hyaluronidase by fully O-sulfonated glycosaminoglycans. Archives of Biochemistry and Biophysics, New York, v. 370, n. 2, p. 176-182, 1999.

TOOLE, B. P. et al. Hyaluronate-cell interactions. In: TRELSTAD, R. L. (Ed.). The role of extracellular matrix in development. New York: Alan R. Liss, 1984. p. 43-66.

TOYAMA, M. $\mathrm{H}$. et al. Biochemical characterization of two crotamine isoforms isolated by a single step RP-HPLC from Crotalus durissus terrificus (South American rattlesnake) venom and their action on insulin secretion by pancreatic islets. Biochimica et Biophysica Acta, Amsterdam, v. 1474, n. 1, p. 56-60, 2000.

TOYAMA, M. H. et al. Structural, enzymatic and biological properties of new PLA 2 isoform from Crotalus durissus terrificus venom. Toxicon, Oxford, v. 41, n. 8, p. 10331038, 2003.

TOYAMA, D.O. et al. Effect of umbelliferone (7-hydroxycoumarin, 7-HOC) on the enzymatic, edematogenic and necrotic activities of secretory phospholipase $A_{2}$ $\left(\mathrm{sPLA}_{2}\right)$ isolated from Crotalus durissus collilineatus venom. Toxicon, Oxford, v. 53, n. 4, p. 417-426, 2009.

TSENG, S. J.; HSU, J. P. A comparison of the parameter estimating procedures for the Michaelis-Mentel model. Journal of Theoretical Biology, London, v. 145, n. 4, p. 457-464, 1990.

TU, A. T.; HENDON, R. R. Characterization of lizard venom hyaluronidase and evidence for its action as a spreading factor. Comparative Biochemistry and Physiology B - Biochemistry and Molecular Biology, Oxford, v. 76, n. 1, p. 377-383, 1983. 
UETZ, T. The EMBL reptile database. [2012]. Disponível em: <http://www.reptiledatabase.org/>. Acesso em: 02 mai. 2012.

VENKATESK, K. H.; RAO, G. S. U. Treatment of supraglottic airway edema by local hyaluronidase. Anesthesiology, Philadelphia, v. 106, n. 6, p. 1254-1255, 2007.

VESTERBERG, O. Isoelectric focusing of proteins in polyacrylamide gels. Biochimica et Biophysica Acta (BBA) - Protein Structure, Amsterdam, v. 257, n. 1, p. 11-19, 1972.

VOLFOVA, V. et al. Hyaluronidase of bloodsucking insects and its enhancing effect on Leishmania infection in mice. Plos Neglected Tropical Diseases, San Francisco, v. 2, n. 9, p. 1-8, 2008.

WAINAINA, N. et al. Fluorescence detection of amino acids in the postcleavage conversions for manual sequencing of a peptide. Analytical Biochemistry, New York, v. 374, n. 2, p. 423-425, 2008.

WARRELL, D. A. Snake bite. Lancet, London, v. 375, n. 9708, p. 77-88, 2010.

WARRELL, D. A. Venomous bites, stings, and poisoning. Infectious Disease Clinics of North America, Philadelphia, v. 26, n. 2, p. 207-223, 2012.

WEISSMAN, B.; MEYER, K. The structure of hyalobiuronic acid and of hyaluronic acid from umbilical cord. Journal of American Chemistry Society, Washington, v. 76, p. 1753-1757, 1954.

WIKIPEDIA. Fitogeografia. [2010]. Disponível em: <http://pt.wikipedia.org/wiki/ Fitogeografia>. Acesso em 06 nov. 2010.

WRIGHT, R. P. et al. Enzymes and toxins of scorpion venom Palamneus gravimanus. Toxicon, Oxford, v. 15, n. 3, p. 197-205, 1977.

WÜSTER, W. et al. Tracing an invasion: landbridges, refugia, and the phylogeography of the Neotropical rattlesnake (Serpentes: Viperidae: Crotalus durissus). Molecular Ecology, Oxford, v. 14, p. 1095-1108, 2005a.

WÜSTER, W. et al. No rattesnakes in the rainforests: reply to Gosling and Bush. Molecular Ecology, Oxford, v. 14, p. 3619-3621, 2005b.

$\mathrm{XU}, \mathrm{X}$. et al. Purification and partial characterization of hyaluronidase from five pace snake (Angkistrodon acutus) venom. Toxicon, Oxford, v. 20, n. 6, p. 973-981, 1982.

YINGPRASERTCHAI, S.; BUNYASRISAWAT, S.; RATANABANANGKOON, K. Hyaluronidase inhibitors (sodium cromoglycate and sodium auro-thiomalate) reduce the local tissue damage and prolong the survival time of mice injected with Naja kaouthia and Calloselasma rhodostoma venoms. Toxicon, Oxford, v. 42, n. 6, p. 635646, 2003. 
ZANEVELD, L. J. D.; POLAKOSKI, K. L.; SCHUMACHER, G. F. B. Properties of acrosomal hyaluronidase from bull spermatozoa - evidence for its similarity to testicular hyaluronidase. Journal of Biological Chemistry, Baltimore, v. 248, n. 2, p. 564-570, 1973.

ZHANG, G. Y. et al. Crystal structure of Thermus aquaticus core RNA polymerase at 3.3 angstrom resolution. Cell, Cambridge, v. 98, n. 6, p. 811-824, 1999.

ZHONG, D. et al. A hyaluronidase from the snake venom of Agkistrodon blomhoffii ussurensis of Changbai mountain: isolation and characterization. International Journal of Biology, Toronto, v. 2, n. 2, p. 171-180, 2010. 
